University of Nebraska - Lincoln DigitalCommons@University of Nebraska - Lincoln

Insecta Mundi

Center for Systematic Entomology, Gainesville,

Florida

8-11-2017

\title{
Description of a new genus of primitive ants from Canadian amber, with the study of relationships between stem- and crown-group ants (Hymenoptera: Formicidae)
}

Leonid H. Borysenko

Canadian National Collection of Insects, Arachnids and Nematodes, leonidborysenko@yahoo.com

Follow this and additional works at: http://digitalcommons.unl.edu/insectamundi

Part of the Ecology and Evolutionary Biology Commons, and the Entomology Commons

Borysenko, Leonid H., "Description of a new genus of primitive ants from Canadian amber, with the study of relationships between stem- and crown-group ants (Hymenoptera: Formicidae)" (2017). Insecta Mundi. 1067.

http://digitalcommons.unl.edu/insectamundi/1067

This Article is brought to you for free and open access by the Center for Systematic Entomology, Gainesville, Florida at DigitalCommons@University of Nebraska - Lincoln. It has been accepted for inclusion in Insecta Mundi by an authorized administrator of DigitalCommons@University of Nebraska - Lincoln. 


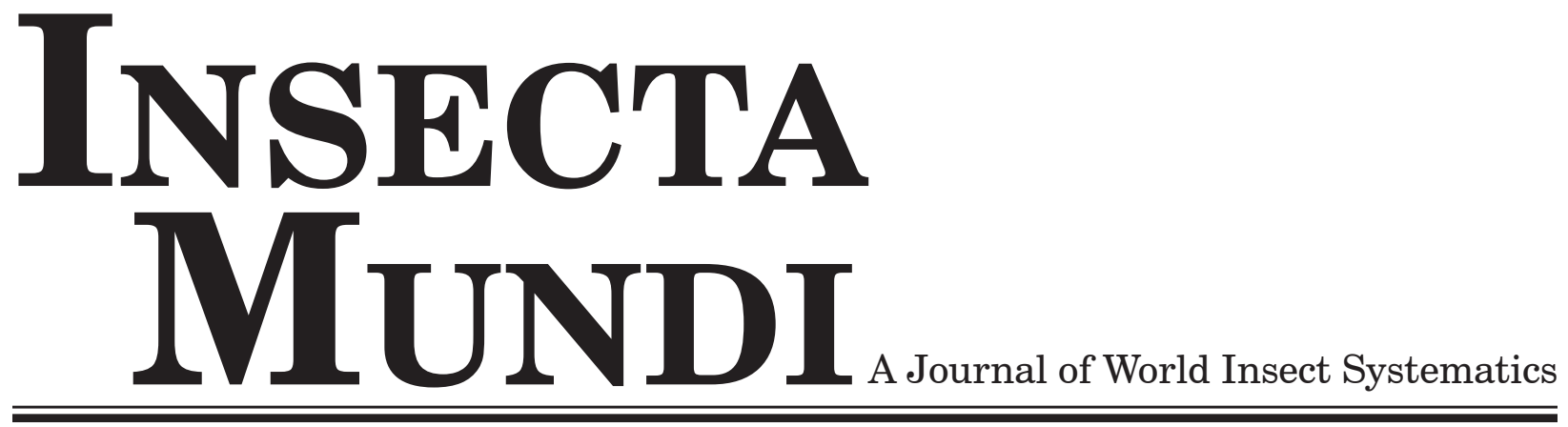

0570

Description of a new genus of primitive ants from Canadian amber, with the study of relationships between stem- and crown-group ants (Hymenoptera: Formicidae)

Leonid H. Borysenko

Canadian National Collection of Insects, Arachnids and Nematodes AAFC, K.W. Neatby Building

960 Carling Ave., Ottawa, K1A 0C6, Canada

Date of Issue: August 11, 2017

Center for Systematic Entomology, Inc., Gainesville, FL 
Leonid H. Borysenko

Description of a new genus of primitive ants from Canadian amber, with the study of relationships between stem- and crown-group ants (Hymenoptera: Formicidae) Insecta Mundi 0570: 1-57

ZooBank Registered: urn:lsid:zoobank.org:pub:C6CCDDD5-9D09-4E8B-B056-A8095AA1367D

Published in 2017 by

Center for Systematic Entomology, Inc.

P. O. Box 141874

Gainesville, FL 32614-1874 USA

http://centerforsystematicentomology.org/

Insecta Mundi is a journal primarily devoted to insect systematics, but articles can be published on any non-marine arthropod. Topics considered for publication include systematics, taxonomy, nomenclature, checklists, faunal works, and natural history. Insecta Mundi will not consider works in the applied sciences (i.e. medical entomology, pest control research, etc.), and no longer publishes book reviews or editorials. Insecta Mundi publishes original research or discoveries in an inexpensive and timely manner, distributing them free via open access on the internet on the date of publication.

Insecta Mundi is referenced or abstracted by several sources including the Zoological Record, CAB Abstracts, etc. Insecta Mundi is published irregularly throughout the year, with completed manuscripts assigned an individual number. Manuscripts must be peer reviewed prior to submission, after which they are reviewed by the editorial board to ensure quality. One author of each submitted manuscript must be a current member of the Center for Systematic Entomology.

Chief Editor: David Plotkin, e-mail: insectamundi@gmail.com

Assistant Editor: Paul E. Skelley, e-mail: insectamundi@gmail.com

Head Layout Editor: Eugenio H. Nearns

Editorial Board: J. H. Frank, M. J. Paulsen, Michael C. Thomas

Review Editors: Listed on the Insecta Mundi webpage

Manuscript Preparation Guidelines and Submission Requirements available on the Insecta Mundi webpage at: http://centerforsystematicentomology.org/insectamundi/

Printed copies (ISSN 0749-6737) annually deposited in libraries:

CSIRO, Canberra, ACT, Australia

Museu de Zoologia, São Paulo, Brazil

Agriculture and Agrifood Canada, Ottawa, ON, Canada

The Natural History Museum, London, UK

Muzeum i Instytut Zoologii PAN, Warsaw, Poland

National Taiwan University, Taipei, Taiwan

California Academy of Sciences, San Francisco, CA, USA

Florida Department of Agriculture and Consumer Services, Gainesville, FL, USA

Field Museum of Natural History, Chicago, IL, USA

National Museum of Natural History, Smithsonian Institution, Washington, DC, USA

Zoological Institute of Russian Academy of Sciences, Saint-Petersburg, Russia

Electronic copies (Online ISSN 1942-1354, CDROM ISSN 1942-1362) in PDF format:

Printed CD or DVD mailed to all members at end of year. Archived digitally by Portico.

Florida Virtual Campus: http://purl.fcla.edu/fcla/insectamundi

University of Nebraska-Lincoln, Digital Commons: http://digitalcommons.unl.edu/insectamundi/

Goethe-Universität, Frankfurt am Main: http://nbn-resolving.de/urn/resolver.pl?urn:nbn:de:hebis:30:3-135240

Copyright held by the author(s). This is an open access article distributed under the terms of the Creative Commons, Attribution Non-Commercial License, which permits unrestricted non-commercial use, distribution, and reproduction in any medium, provided the original author(s) and source are credited. http://creativecommons.org/ licenses/by-nc/3.0/

Layout Editor for this article: Eugenio H. Nearns 


\title{
Description of a new genus of primitive ants from Canadian amber, with the study of relationships between stem- and crown-group ants (Hymenoptera: Formicidae)
}

\author{
Leonid H. Borysenko \\ Canadian National Collection of Insects, Arachnids and Nematodes \\ AAFC, K.W. Neatby Building \\ 960 Carling Ave., Ottawa, K1A 0C6, Canada \\ leonidborysenko@yahoo.com
}

\begin{abstract}
A detailed study of the holotype of Sphecomyrma canadensis Wilson, 1985 (Hymenoptera: Formicidae) from Canadian amber has led to the conclusion that the specimen belongs to a new genus, here named Boltonimecia gen.n. Since the taxonomy of stem-group ants is not well understood, in order to find the taxonomic position of this genus, it is necessary to review the classification of stem-group ants in a study of their relation to crown-group ants. In the absence of data for traditional taxonomic approaches, a statistical study was done based on a morphometric analysis of antennae. Scape elongation is believed to play an important role in the evolution of eusociality in ants; however, this hypothesis has never been confirmed statistically. The statistical analysis presented herein lends support to the view that antennal morphology reliably distinguishes stem-group ants from crown-group ants, to determine whether a species belongs to one or the other group. This, in turn, may indicate a relationship exists between eusociality and scape elongation. A review of Cretaceous records of ants is made and the higher classification of Formicidae with definitions of stem and crown groups is proposed. Newly obtained data are discussed focusing particularly on the origin, evolution and diversity of ants.
\end{abstract}

Key Words. Formicidae, stem-group ants, crown-group ants, taxonomy, Cretaceous.

\section{Introduction}

Mammals and birds immediately come to mind when thinking of the groups of animals that began to flourish after the Cretaceous-Paleogene (K-Pg) extinction event. Ants, however, also started to flourish at that time. Ants were rare in the Late Cretaceous, but in the Cenozoic they underwent an explosive radiation to become one of the largest and most widespread groups of terrestrial animals (Hölldobler and Wilson 1990).

Fossilized ants are preserved as imprints in rock or as amber inclusions (reviewed in LaPolla et al. (2013)). Among only a handful of amber sites known to contain ants, Canadian amber is of a special interest: dating from a part of the Campanian, 78-79 million years (Ma) old (McKellar and Wolfe 2010), it contains traces of one of the latest Cretaceous ecosystems existed in North America only 10 Ma before the K-Pg extinction event.

It is noteworthy that both crown- (i.e., the descendants of the most recent common ancestor of all extant ants) and stem-group ants (i.e., all taxa that fall outside the crown clade but more closely related to it than to other Aculeata) are found in Canadian amber. These groups had probably coexisted for the most part of the Cretaceous, but only in Canadian amber are they present in almost equal numbers. Four species from Canadian amber represent recent subfamilies - Dolichoderinae (Eotapinoma macalpini Dlussky, Chronomyrmex medicinehatensis McKellar, Glasier and Engel), Ectatomminae (Canapone dentata Dlussky), Aneuretinae (Cananeuretus occidentalis Engel and Grimaldi), and at least three species represent the extinct subfamily Sphecomyrminae: Sphecomyrma canadensis, Haidoterminus cippus McKellar, Glasier and Engel, Sphecomyrma sp. (Wilson 1985; Grimaldi et al. 1997; Dlussky 1999a; Engel and Grimaldi 2005; McKellar et al. 2013a,b).

The present paper focuses on the holotype of Sphecomyrma canadensis. It has been noted before that the description of $S$. canadensis is unsatisfactory (Dlussky 1996), and the paratype is not conspecific with the holotype (Dlussky 1999a). While examining the holotype, I found that the head, mandibles and antennae's distal parts were almost invisible. After the amber was polished, some important morphological details were revealed. What had seemed to be a black inclusion hiding the head, turned out to be a thick, raised head platform with posterior stick-like processes. Based on these unique morphological structures, I decided to treat the specimen as belonging to a genus not previously described. 
The next step was to find the taxonomic position of this new genus. Needless to say, the classification of stem-group ants is still in its infancy. Their morphological data are scarce, molecular data are impossible to obtain. Stem-group ants have never been the subject of a taxonomic revision, and rarely (Baroni Urbani et al. 1992; Grimaldi et al. 1997; Barden and Grimaldi 2016) were included in a morphological cladistic analysis. At the moment, stem-group ants are assigned to two poorly supported subfamilies, Sphecomyrminae and Armaniinae (Bolton 2003), but some species, such as Myanmyrma gracilis Engel and Grimaldi and Camelomecia janovitzi Barden and Grimaldi are so bizarre that they cannot be assigned even to these subfamilies and are left as incertae sedis (Engel and Grimaldi 2005; Barden and Grimaldi 2016). There is also a long-standing debate regarding the taxonomic status of Armaniinae, which either represent the most basic stem-group ants (Dlussky 1983), or are sexuals of Sphecomyrminae preserved only in rock imprints due to their large size (Wilson 1987). In the absence of sufficient morphological data, there is a need to invent new methods of taxonomic analysis based on principal differences between stem- and crown-group ants.

In an attempt to fill this gap, I followed the idea that antennal morphology can be a diagnostic tool to distinguish between stem- and crown-group ants. This idea was first expressed by Wilson, Carpenter and Brown (1967) in their diagnosis of Sphecomyrminae, and later explained in terms of evolutionary history and expanded by means of comparative analysis by Dlussky (1983). Since then, antennal characteristics have been used in diagnoses of stem-group subfamilies including Bolton's system (2003), the most comprehensive for the time being. The fact that they have never been tested by means of statistics is surprising, considering a highly interesting biological background of Dlussky's hypothesis: scape elongation was necessary for the emergence of eusociality in ants (Dlussky 1983).

The final logical step of the present study was to develop the higher classification of the ants including both stem and crown branches. This important issue that affects our thinking about ant origins has been underestimated in previous works (Ward 2007).

\section{Materials and Methods}

Examination of the amber inclusion. Photographs were taken with a Nikon D1X digital camera attached to the microscope Leica Z6 APO. The photographs were used to make drawings, which were then computer generated and adjusted using Adobe Photoshop. All measurements were made with an ocular micrometer and are in millimeters. The following measurements were recorded: HL - head length (measured in full-face view as a straight line from the anterior-most point of median clypeal margin to the mid-point of the posterior margin of the head), HW - head width (maximum head width in full-face view), SL - scape length (maximum length excluding articular condyle) F1L-F9L - length of flagellomeres $\left(1^{\text {st }}-9^{\text {th }}\right)$, AL - antenna length, ML - mandible length (maximum length of its horizontal part), WL - Weber's length (the distance from the anterodorsal margin of the pronotum to the posteroventral margin of the propodeum), TL - total body length.

Taxon sampling and morphometry. I used all morphometric data on antennae and heads of stemgroup ants available from the literature; I also either made measurements or used published data on antennae and heads of crown-group ants representing all extant subfamilies (Table S1). For the measurements, only species with both a detailed description in the literature and high-resolution images available from AntWeb (Fisher 2002) were selected. I also aimed that the species would cover the broad phylogenetic diversity. All subfamilies in the data set are represented by one species, except for the largest ones (Ponerinae, Dolichoderinae, Formicinae, Myrmicinae), which are represented by two species. Recently, six subfamilies of the dorylomorph group have been subsumed into a single subfamily, Dorylinae (Brady et al. 2014), but here, in order to cover broader diversity, all six subfamilies were sampled as valid groups.

Measurements were made on mounted specimens using a Wild M10 stereomicroscope with an accuracy $\pm 1 \mu \mathrm{m}$. For all studied stem- and crown-group ants, I calculated nine indices showing length of antennal parts compared to head length (indices SL/HL, FL/HL, PL/HL, F1L/HL, F2L/HL) and compared to the rest of the antenna (indices SL/FL, PL/(AL-PL), F1L/(AL-F1L), F2L/(AL-F2L)) (Tables S2, S3). In these indices, HL - head length (see definition above), SL - scape length (see definition above), 
FL - length of flagellum, PL - length of pedicel, F1L and F2L - length of $1^{\text {st }}$ and $2^{\text {nd }}$ flagellomeres respectively. HL rather than HW was used for the indices, as HL is available for more fossil species; in addition, using HL, the data can be compared with Dlussky's morphometric data (Dlussky 1983; Dlussky and Fedoseeva 1988). Two more indices, AL/HL and SL/AL (where AL - antenna length, SL scape length), were only used to compare the data obtained with Dlussky's data on the Vespoidea and Apoidea (Dlussky and Fedoseeva 1988).

For general observations (the shape of the pedicel, the morphology of middle and terminal antennal segments), high resolution images available from AntWeb were used. To study the width of the petiolar attachment of the Armaniinae, the petiolar index, PG/PH (where PG - the width of the petiole in the broadest point of its attachment to the gaster; $\mathrm{PH}$ - the maximum height of the petiole) was calculated.

Statistical analysis. Two statistical tests for equality of means were performed: the Student's t-test and a one-way ANOVA with planned comparisons. In addition, correlation and regression analysis as well as canonical discriminant analysis were performed.

Power analysis was carried out using the program $G^{*}$ Power (Faul et al. 2007). Despite the scarcity of the data on extinct taxa, in all cases where the t test showed statistically significant results, statistical power was also high. An unbalanced design in an ANOVA, however, could be a problem (McDonald 2014). Indeed, the results showed that the unbalanced design in which extinct ants are underrepresented, had low statistical power. In such a case, the only way to confirm reliability of the results is to reduce large groups to a size of the smallest one, and run the power analysis and ANOVA again. After such manipulation, high statistical power was obtained, whereas the ANOVA results were almost identical to those of the unbalanced design.

The next concern about the reliability of the statistical results was a measurement error. Since the measurements of extinct taxa were taken independently by different persons, with different material and calibration, those slight differences might presumably alter the conclusions obtained. In order to check the extent to which the results were sensitive to errors, $10 \%$ (a large measurement error) were added/subtracted to/from the indices and to/from the measurements. A random number generator was used to apply these modifications. Then the modified data set was analyzed with the ANOVA and t test again. In all cases no noticeable effect was observed, so the statistical model proved to be robust and not sensitive to large errors.

Supplementary material (Tables S1-S18) is available in Appendix 1.

The collection acronym used in this study is as follows: CNC - Canadian National Collection of Insects, Arachnids and Nematodes (Ottawa, Canada).

\section{Systematic Palaeontology}

Family Formicidae Latreille, 1809

\section{Subfamily Sphecomyrminae Wilson and Brown, 1967}

\section{Tribe Zigrasimeciini, trib.n.}

Genera. Zigrasimecia Barden and Grimaldi, 2013 (type genus), Boltonimecia gen.n..

Diagnosis (workers). See "The higher classification of the ants" below.

\section{Genus Boltonimecia, gen.n.}

Type and only known species. Boltonimecia canadensis (Wilson, 1985)

Diagnosis. As for the tribe. 
Etymology. This genus is dedicated to the renowned myrmecologist Barry Bolton.

\section{Boltonimecia canadensis (Wilson, 1985), comb.n.}

Fig. 1, 2

Taxonomic history. Sphecomyrma canadensis Wilson, 1985: 206, fig. 1, 2 (w.)

Materials examined. Holotype, worker. The specimen is preserved in a clear orange piece of Canadian amber, $8 \times 3 \times 2 \mathrm{~mm}$ in size, from Medicine Hat, Alberta (J. F. McAlpine, CAS 330), held in the CNC. The preservation is excellent, except for the mesosoma, left flagellum and the right side of the head, which are flattened due to compression; also, a small proximal part of both scapes is gone.

The specimen described as the paratype of Sphecomyrma canadensis (Wilson, 1985) (CAS 205, CNC) is represented by poorly preserved body fragments without taxonomically informative characters, and thus should not be regarded as the paratype.

Diagnosis. As for the genus.

Redescription of type. HL $0.73 \mathrm{~mm}$; HW $0.8 \mathrm{~mm}$; SL $0.5 \mathrm{~mm}$; ML $0.48 \mathrm{~mm}$; WL $1.2 \mathrm{~mm}$; TL $3.4 \mathrm{~mm}$. Head small compared with the rest of the body (1/5 of body length), slightly wider than long, seems to be triangular when seen from above. Its dorsal part thick, raised and curved in profile, thus forming a "shield" (Fig. 2B-D). Two stick-like processes directed anterolaterally protrude from the posterolateral edges of the head. Compound eyes and ocelli absent. The stick-like processes are doubtfully deformed eyes, since they have no trace of visible facets and are densely covered with appressed pubescence, similar to that on the front of the head. Clypeus small, in profile strongly convex, does not extend back between the antennal sockets; its lateral margins produced as semicircular lobes covering the insertions of the mandibles; its anterior margin bears 25 peg-like setae $0.01 \mathrm{~mm}$ long. Clypeal width $0.5 \mathrm{~mm}$ (without lateral lobes), length - $0.15 \mathrm{~mm}$.

Mandibles linear, two toothed, curved at almost $90^{\circ}$. The apical tooth is longer than the preapical one: $0.15 \mathrm{~mm}$ and $0.06 \mathrm{~mm}$, respectively. On the inner side of the apical tooth there is a longitudinal impression, which probably corresponds to the position of the other mandible when mandibles are closed. Mandible length: $0.48 \mathrm{~mm}$ (horizontal part), $0.17 \mathrm{~mm}$ (vertical part).

Antennae 11-segmented; when laid back the apex of the scape just reaches the occipital margin. Insertions of antennae are not far apart $(0.17 \mathrm{~mm})$, partly exposed, and touching the clypeus. Toruli not fused to the frontal lobes. Antennal segment measurements (mm): SL - 0.5, PL - 0.2, F1L - 0.15, F2L - 0.2, F3L-F8L - 0.17, F9L - 0.25; AL - 2.32.

Metanotal groove distinct. Propodeum slightly lower than promesonotum, without teeth or spines; propodeal spiracles high. Orifice of metapleural gland protected by guard setae. Petiole $0.4 \mathrm{~mm}$ long, pedunculate (peduncle $0.1 \mathrm{~mm}$ long, node $0.2 \mathrm{~mm}$ high). Gaster ovate, $1.1 \mathrm{~mm}$ long; helcium projects from abdominal segment III low down on its anterior face; abdominal segment IV without presclerites. Sting present; length of its extruded portion $0.05 \mathrm{~mm}$.

Legs long: $3.3 \mathrm{~mm}$ forelegs (shortest), $5.07 \mathrm{~mm}$ hind legs (longest; 1.5 times of body length); measurements of leg segments are given in Table 1. Pretarsal claws with one preapical tooth (Fig. 1D). Each tarsal segment with two stiff setae on both sides apically; protibia with one pectinate and two simple spurs; mesotibia and metatibia with one pectinate and one simple spur (Fig. 1E).

Head dorsum, antennae, stick-like processes covered with dense short appressed pubescence. Lateral head margins with erect and suberect hairs. Anterior clypeal margin, middle of clypeus, anterior margin of the "shield" bear long erect hairs directed anteriorly. External mandibular margins covered with suberect hairs. Mesosoma, legs, and gaster completely covered with short appressed pubescence. In addition to pubescence, middle and hind tibiae covered with sparse suberect hairs; erect hairs project from the apex of middle and hind femurs; ventral surfaces of coxae with long erect hairs; pronotum and propodeum bear long white erect hairs tapering to sharp points (especially long on pronotum); gaster covered with sparse suberect hairs, which is longer on the ventral surface. 
Body sculpture not distinct. Body colored as surrounding amber material, but the ventral surfaces of coxae, gaster, proximal halves of tibiae, lower half of propodeum are brown to black. Head dorsum and pronotum black, opaque.

Gyne and male unknown.

Discussion. Some authors have already noticed that Sphecomyrma canadensis shares no synapomorphy with Sphecomyrma Wilson and Brown, namely, it lacks an elongated F1 (Dlussky 1996; Grimaldi et al. 1997; Engel and Grimaldi 2005). Dlussky and Fedoseeva have even suggested that because of unique antennal characters, such as the elongated scape and pedicel, this species should be assigned to its own new subfamily (Dlussky and Fedoseeva 1988). Here more unique characters that set B. canadensis apart from all known Cretaceous ants were discovered.

Boltonimecia canadensis has 11-segmented antennae - a unique character unknown in any other Cretaceous ants. A small proximal part of both scapes is missing, but the left scape-pedicel joint is intact, and thus one can confidently infer about the scape length. This joint is not the one between the pedicel and F1 because (1) it is curved near the base, which is a distinct feature of the pedicel only; and (2) spatial localization of the scape and the flagellum infers that there is no room left for one more antennomere between them. In general, the relative size of the antennomeres is not different from Wilson's drawings (Wilson 1985). The only exception is the distal parts of the antennae, which are curled back under the head and were almost invisible before additional polishing; this probably led to Wilson's assumption about the 12-segmented antenna as in Sphecomyrma.

The most distinctive character of B. canadensis is the specialized head: the thick "shield" (most likely formed by the laterally expanded frontal lobes), stick-like processes, and long sensory hairs anteriorly. Some Myrmicinae, Aulacopone relicta Arnol'di (Heteroponerinae) and the Agroecomyrmecinae also have shield-like heads formed by the expanded frontal lobes. In the Myrmicinae, unlike B. canadensis, the median portion of the clypeus usually inserted between the antennal sockets (Bolton 2003). In $A$. relicta, the clypeus is shallow, but, unlike $B$. canadensis, the antennal insertions are close together, and the fronto-clypeal part of the head is extended forwards and covers the mandibles (Taylor 1980). All species of an enigmatic subfamily Agroecomyrmecinae have shield-like heads; arboreal Ankylomyrma coronacantha Bolton also has dentiform processes on the occipital margin, projecting especially strongly at the occipital corners (Bolton 1973), in which it closely resembles the specialized head of Boltonimecia. However, in the Agroecomyrmecinae the clypeus is large and broadly inserted between the frontal lobes. In most Ponerini the clypeus is narrowly inserted between the antennal sockets, but their confluent frontal lobes are thin and never form a "shield". In the Proceratiinae, the clypeus is reduced, and the antennae inserted close to the anterior head margin. Some Proceratiinae (Discothyrea Roger) have the frontal lobes fused and forming a small raised platform behind the level of the antennal sockets, the sides of which are strongly convergent anteriorly (Bolton 2003).

Unfortunately, all these interesting morphological similarities tell us little about the evolutionary relationship of $B$. canadensis, because similarities between a stem-group species and a living species have likely evolved through parallel evolution as a result of adaptation to similar habitats. Regarding the last, the lack of eyes and ocelli, as well as long sensory hairs on the anterior head margin may suggest a cryptic lifestyle. However, blind extant ants are not always exclusively subterranean (e.g., Dorylus Fabricius), and long legs of Boltonimecia speak in favor of an arboreal or above-ground lifestyle. The possibility that the eyes of Boltonimecia are reduced to a single facet, and thus simply invisible in amber cannot be rejected either. Therefore, determining the evolutionary relationship and the phylogenetic position of $B$. canadensis is a major challenge. In order to address this issue, it is necessary first to consider the classification of stem-group ants and their relationship with crown-group ants - a task that has rarely been undertaken to date.

\section{What is the difference between stem- and crown-group ants?}

The stem- and crown-group concepts have been developed with the introduction of phylogenetic systematics in the mid-20 $0^{\text {th }}$ century (Hennig 1966). By definition, the crown-group is the clade that includes the last common ancestor of all living taxa and all its descendants; the pan- or total group is 
the clade comprised of the crown-group and all taxa more closely related to it than to any other extant organism; finally, the stem-group is a paraphyletic group composed of the total group excluding the crown-group (e.g., Ax 1985). From this, the ant subfamilies Sphecomyrminae and Armaniinae, as well as incertae sedis genera Myanmyrma Engel and Grimaldi and Camelomecia Barden and Grimaldi are stem-group ants; all living ant taxa plus most of the known extinct genera, such as Kyromyrma Grimaldi and Agosti and Canapone Dlussky, are crown-group ants; both groups, together, form the pan-group Formicidae, the ants.

Among the plesiomorphic characters useful to differentiate between stem- and crown-group ants are the following: the broad attachment of the petiole to the gaster, pretarsal claws with a preapical tooth, bidentate mandibles, two spurs on meso- and metatibiae, short scape, trochantellus, peg-like setae on the anterior margin of the clypeus, and ocelli (Dlussky 1983; Bolton 2003; LaPolla et al. 2013). At first glance, some of these characters seem to be important but others are not that reliable.

The petiole in the non-ant Vespoidea is less differentiated and more broadly attached to the gaster than in the Formicidae, except for the only ant subfamily Amblyoponinae. This may be a good indication that the broad attachment is a clearly plesiomorphic condition. If this assumption is correct, all presently known stem-group ants should be considered as quite advanced, because they all have differentiated petioles, similarly to crown-group ants. The problem of the broad petiole-gaster attachment in the Armaniinae (Dlussky 1983) remains open, and will be discussed in details below.

A preapical tooth on the pretarsal claws is present in many crown-group ants, such as the poneroids and primitive formicoids - Myrmeciinae, Pseudomyrmecinae, Dorylinae (Dlussky and Fedoseeva 1988), as well as in virtually all stem-group ants. It is also common in other Vespoidea.

Bidentate mandibles are common in the Vespoidea and Apoidea, and universal for stem-group ants. In crown-group ant females, bidentate mandibles are mainly present in the poneroids and primitive formicoids, while being quite rare in advanced formicoids - Formicinae, Myrmicinae, Dolichoderinae (Bolton 2003). Similarly, in crown-group ant males, they are common in the poneroids, but rare in the formicoids: in the Formicinae and Myrmicinae they are present in 1/4 of the genera; rarely present in the Dolichoderinae, ectaheteromorphs, Pseudomyrmecinae (Bolton 2003). It is believed that bidentate mandibles evolved in crown-group ants as a result of the reduction of triangular mandibles (Dlussky and Fedoseeva 1988).

Two spurs on meso- and metatibiae are common in the poneroids and primitive formicoids (Bolton 2003), in all stem-group ants, as well as in other Vespoidea. Haidoterminus cippus was described with a single metatibial spur and two mesotibial spurs (McKellar et al. 2013b), which most probably is the result of poor preservation of the legs, because this feature is not known in other Formicidae.

The trochantellus is absent in crown-group ants, except for a putative crown-group species Cananeuretus occidentalis (Engel and Grimaldi 2005). In stem-group ants, it is present in one species of Haidomyrmex (H. scimitarus Barden and Grimaldi) (Barden and Grimaldi 2012), Haidoterminus cippus (McKellar et al. 2013b), both species of Zigrasimecia Barden and Grimaldi (Barden and Grimaldi 2013; Perrichot 2014), some species of Gerontoformica Nel and Perrault (Barden and Grimaldi 2014), and also in the males of Baikuris Dlussky (Dlussky 1987; Grimaldi et al. 1997; Perrichot 2015). In the Armaniinae, this character is not obvious: Armania Dlussky and Pseudarmania Dlussky have been reported either with or without trochantelli (Dlussky 1983; Wilson 1987; Dlussky and Fedoseeva 1988).

Peg-like setae on the anterior clypeal margin are thought to be an important plesiomorphy for the Formicidae (Engel and Grimaldi 2005). In stem-group ants, this character is present in Boltonimecia, Gerontoformica, Myanmyrma, Zigrasimecia; in crown-group ants, it is found in the subfamily Amblyoponinae. Outside ants, peg-like setae exist in some Tiphiidae (Myzinum Latreille) and Bradynobaenidae (Apterogyna Latreille).

Ocelli in workers are often considered an ant plesiomorphy (Engel and Grimaldi 2005). In crowngroup ants, this character is common in extant taxa, mainly in the formicoid clade (subfamilies Myrmeciinae, Pseudomyrmecinae, Dolichoderinae, Formicinae, some Dorylinae), but absent in such Cretaceous genera as Eotapinoma, Chronomyrmex, and Kyromyrma. In stem-group ants, ocelli are present in some Sphecomyrmini.

To sum up, all the mentioned characters can hardly be used to differentiate reliably between stemand crown-group ants. As noted by Dlussky (1983), the most reliable character is probably the elongated scape of crown-group ants, which allows brood and food manipulation and thus favors the emergence 
of eusociality. It is now time to examine this character, along with other morphometric features of the ant antenna, in detail.

\section{The antennal structure as a key distinction between stem- and crown-group ants}

Scape length of more than $25 \%$ of antennal length is thought to be a characteristic of extant (i.e., crown-group) ants (Dlussky and Fedoseeva 1988), although the diagnosis of Sphecomyrminae (Bolton 2003) stated that a "short scape" of Sphecomyrminae means "0.25 times length of funiculus". The role of other antennal parts in distinguishing stem-group ants from crown-group ants may be no less important.

The pedicel of all insects contains the Johnston's organ - a mechanosensory chordotonal organ responsible for hearing, graviception (Kamikouchi et al. 2009) and electric field changes, which may play a role in social communication (Greggers et al. 2013). According to Dlussky and Fedoseeva (1988), the pedicel in crown-group ants is shorter than in stem-group ants, it is narrowed and curved at the base. This enables close contact of the pedicel and the scape, resulting in greater freedom and accuracy of movement of the flagellum, which together with scape elongation led to the emergence of eusociality in ants (Dlussky and Fedoseeva 1988).

The first flagellomere is the longest flagellar segment in stem-group ants, the males of primitive crown-group ants (Dlussky 1983), and the Aculeata closely related to the ants (Engel and Grimaldi 2005); so, it is a symplesiomorphic character (Engel and Grimaldi 2005). Bolton (2003) mentioned this character as a synapomorphy of the Sphecomyrmini (while the longest flagellar segment in the Haidomyrmecini is the second one). In crown-group ants, the first and second flagellomeres are not different from other flagellomeres, except for the elongated terminal one (Dlussky and Fedoseeva 1988).

In stem-group ants, segments beyond the second flagellomere decrease in length towards the apex of the antenna, while in crown-group ants they often increase, ending in a club-shaped expansion of terminal segments (Dlussky and Fedoseeva 1988). In crown-group ant females, the club is common in advanced taxa, except for the formicines in which $3 / 4$ of the genera lack it. Crown-group ant males also rarely have clubs (Bolton 2003). Finally, the entire flagellum in stem-group ants is long and flexuous (Bolton 2003).

Making his hypothesis from a comparison of ants with other Aculeata, Dlussky, however, has not provided any statistical support. This has resulted in criticism and even removal of a character "short scape" from the data matrix as it is "difficult to define" (Grimaldi et al. 1997). Below, I check Dlussky's hypothesis using a statistical analysis of antennal indices and try to expand and generalize the aforementioned observations on the antennal structure.

A comparison of antennal indices of crown- and stem-group ants. Although the indices of the Cretaceous ant males (since none of the Cretaceous ant males has been explicitly associated with conspecific stem-group ant females, they are not called "stem-group ant males" throughout the paper) are within the range of the indices of the crown-group ant males, in most cases they are shifted from the crown-group male mean (Table S3). The statistical tests showed that some differences between these indices were significant (Table S15):

(1) Scape. The indices SL/HL did not show statistically significant differences, while for SL/FL such a difference existed. The latter can be explained by a considerably longer flagellum of the Cretaceous ant males.

(2) Flagellum. The mean of FL/HL is noticeably greater in the Cretaceous ant males than in the crown-group ant males, although a $\mathrm{P}$-value is quite high.

(3) Pedicel. For PL/HL, the difference was statistically insignificant, while for PL/(AL-PL), it was on the verge of significance. The latter again results from a longer flagellum of the Cretaceous ant males.

(4) The first and second segments of the flagellum. The means of F1L/HL and F2L/HL are noticeably greater in the Cretaceous ant males, although $\mathrm{P}$-values are quite high. The differences between F1L/(AL-F1L) as well as F2L/(AL-F2L) are not well understood due to low statistical power.

The male regression lines were similar for FL/HL, F1L/HL, and F2L/HL (Fig. 3). 
The low sample size of the Cretaceous ant males prevents any firm conclusions being drawn; the available data, however, suggest that the Cretaceous ant males might have a longer flagellum, F1, and F2, compared to the crown-group ant males.

The situation is completely different for females, as the statistical analysis showed highly significant differences between the crown- and stem-group ants. The ANOVA analysis for five groups (extant crowngroup ants, Cretaceous crown-group ants, Sphecomyrmini, Haidomyrmecini, Armaniinae) showed that the means of all the indices differed significantly, except for the pedicellar indices: SL/HL: $\mathrm{F}_{4.79}=18.38$, $\mathrm{P}<0.0001 ; \mathrm{FL} / \mathrm{HL}: \mathrm{F}_{3,74}=23.29, \mathrm{P}<0.0001 ; \mathrm{PL} / \mathrm{HL}: \mathrm{F}_{4,78}=1.47, \mathrm{P}=0.22 ; \mathrm{F} 1 \mathrm{~L} / \mathrm{HL}: \mathrm{F}_{4,78}=34.36, \mathrm{P}<0.0001 ; \mathrm{F} 2 \mathrm{~L} /$ HL: $\mathrm{F}_{4,78}=18.01, \mathrm{P}<0.0001 ; \mathrm{SL} / \mathrm{FL}: \mathrm{F}_{3,74}=87.78, \mathrm{P}<0.0001 ; \mathrm{PL} /(\mathrm{AL}-\mathrm{PL}): \mathrm{F}_{3,74}=0.35, \mathrm{P}=0.79 ; \mathrm{F} 1 \mathrm{~L} /(\mathrm{AL}-\mathrm{F} 1 \mathrm{~L})$ : $\mathrm{F}_{3,74}=38.58, \mathrm{P}<0.0001 ; \mathrm{F} 2 \mathrm{~L} /(\mathrm{AL}-\mathrm{F} 2 \mathrm{~L}): \mathrm{F}_{3,74}=18.07, \mathrm{P}<0.0001$. A planned comparison revealed the following picture.

All indices of the Cretaceous crown-group ants are close to the means of the extant crown-group ants (Table S2); the statistical analysis showed no differences between the two groups (Tables S4-S12). The relationships among other groups were more complicated.

Scape (indices SL/FL, SL/HL):

(1) For SL/FL, the stem-group ants differed significantly from the crown-group ants in having lower mean values. The Haidomyrmecini were significantly different from both the crown-group ants and Sphecomyrmini (Table S9).

(2) For SL/HL, the Sphecomyrmini and Armaniinae have significantly lower mean values than the crown-group ants. The Haidomyrmecini have greater means, which are intermediate between the means of the crown-group ants and Sphecomyrmini, Armaniinae (Table S4); Haidomyrmecini's values are often seen in the crown-group ants (Table S2).

(3) For SL/HL, the Armaniinae were not different from the Sphecomyrminae and Sphecomyrmini (Table S4); for SL/FL, the only available index of the Armaniinae is close to the mean of the Sphecomyrmini (Tables S2, S4).

(4) Myanmyrma's indices lie close to the regression line of the Sphecomyrminae (Fig. 4A, 4C). Myanmyrma's SL/HL is similar to the mean of the Sphecomyrmini, Armaniinae, and the lowest value of the crown-group ants obtained in this study, the index of Pseudomyrmex pallidus Smith. Myanmyrma's $\mathrm{SL} / \mathrm{FL}$ is the lowest one, but it is quite close to the minimum value of the Sphecomyrmini (index of Gerontoformica contegus Barden and Grimaldi) (Table S2).

(5) Boltonimecia's SL/HL is close to the mean of the crown-group ants (similar indices are seen in the Dorylinae, Proceratiinae, Myrmicinae, Ponerinae, Agroecomyrmecinae), but greater than that of all Sphecomyrmini and Haidomyrmecini (except for Haidoterminus cippus). Boltonimecia's SL/FL is greater than that of most Sphecomyrmini, but lower than that of several species of the Haidomyrmecini (Table S2).

Pedicel (indices PL/(AL-PL), PL/HL):

(1) For both indices, there was no statistical difference between the groups studied (Tables S6, S10; Fig. 4D). Such stability, as already noted, may be explained by an important function of the pedicel.

(2) The greatest PL/HL is seen in Cananeuretus occidentalis, followed by Gerontoformica cretacica Nel and Perrault, Boltonimecia canadensis, G. rugosus Barden and Grimaldi and Myanmyrma gracilis; all four indices are close to one another and to the greatest value among the crown-group ants found in Martialis heureka Rabeling and Verhaagh (Table S2). G. cretacica, M. gracilis and C. occidentalis appear separate from the rest of the species in the bivariate plot (Fig. 4D).

Flagellum (index FL/HL):

(1) The stem-group ants were always statistically different from the crown-group ants in having longer flagella (Table S5).

(2) The greatest FL/HL (i.e., the longest flagellum) is in Gerontoformica rubustus Barden and Grimaldi, G. magnus Barden and Grimaldi, Myanmyrma gracilis and G. cretacica (Table S2). The extremely elongated flagella of these species resemble only the male flagella (Table S3).

(3) The Haidomyrmecini were not different from the Sphecomyrminae (Table S5).

(4) The indices of Boltonimecia canadensis and the only species of the Armaniinae for which FL/ HL can be calculated (Pseudarmania rasnitsyni Dlussky) are about equal to the mean of the Sphecomyrminae (Table S2).

The first segment of the flagellum (indices F1L/(AL-F1L), F1L/HL): 
(1) Most stem-group ants, except for the Haidomyrmecini, had significantly greater means than the crown-group ants (Tables S7, S11). The Haidomyrmecini's means are intermediate between those of the Sphecomyrmini and crown-group ants, with weak statistical relationships (Tables S7, S11).

(2) The Armaniinae were not statistically different from the Sphecomyrminae and Sphecomyrmini (Table S7).

(3) The indices of Boltonimecia are within the range of the indices of the Sphecomyrminae, although the former are not as great as the indices of most Sphecomyrmini (Table S2).

(4) Myanmyrma's F1L/HL is the greatest of all the species reported, followed by Gerontoformica subcuspis Barden and Grimaldi, and G. cretacica (Table S2); Myanmyrma is separate from the rest of the species in the bivariate plot (Fig. 4E). M. gracilis and G. subcuspis have the greatest F1L/(AL-F1L) (Table S2).

The second segment of the flagellum (indices F2L/(AL-F2L), F2L/HL):

(1) The indices of the stem-group ants are usually significantly greater than those of the crowngroup ants (Tables S8, S12).

(2) In the bivariate plot of F2L vs HL (like in the plots of SL vs HL and PL vs HL) the Armaniinae lie close to Sphecomyrma mesaki Engel and Grimaldi (Fig. 4A, 4D, 4F).

(3) Boltonimecia's indices are close to the mean of the Sphecomyrminae (Tables S2, S8, S12).

(4) F2L/HL of Myanmyrma gracilis, Gerontoformica subcuspis, and G. cretacica is close to the greatest value found in Haidomyrmex scimitarus. The greatest F2L/(AL-F2L) is found in H. scimitarus and G. subcuspis (Table S2).

General observations on middle and terminal flagellomeres. (1) Crown-group ant females: Following F2 or F3, segment width (and often length) increases. This increase may be gradual or sharp (forming an antennal club). A very slight width increase is seen even in species with filiform antennae (which are marked " 0 " in Appendix 2 of Bolton (2003)), for example in the Paraponerinae, Formicinae, Myrmeciinae. Also in the species with filiform antennae, the terminal flagellomere is often about 1.5 times longer than the penultimate one. The exceptions are the genera without an increase in width (Eciton Latreille) or length (Paraponera Smith). In some cases, the pattern resembles that of some stem-group ant females: segment length diminishes towards the apex (Eciton, Nomamyrmex Borgmeier, Leptomyrmex Mayr), but often such a decrease is accompanied by the elongation of the terminal segment (Eciton, Nomamyrmex, Leptomyrmex), and/or with a slight increase in width of last segments (Myrmecia Fabricius).

(2) Stem-group ant females: Antennae are always filiform without a club; middle and terminal segments are similar in size, but in some cases the most distal segments are slightly thicker (in Gerontoformica orientalis Engel and Grimaldi, G. contegus, Haidomyrmodes mammuthus, Haidoterminus cippus). The terminal segment is often about 1.2-1.5 times longer than the penultimate one (except G. cretacica, Haidomyrmex scimitarus, Haidomyrmodes mammuthus). In some cases, the length of flagellomeres diminishes towards the apex (G. cretacica) or very slightly increases (G. orientalis, G. occidentalis). In Sphecomyrma mesaki, Myanmyrma gracilis, Haidomyrmex zigrasi, Haidoterminus cippus, and G. subcuspis it diminishes, then increases; in Haidomyrmex scimitarus it diminishes, then increases, and finally diminishes again. Thus, G. cretacica is unique in having flagellomeres which diminish in length towards the apex; this pattern resembles that of the Cretaceous males and Paraponera. Haidomyrmex scimitarus and Haidomyrmodes mammuthus also exhibit unusual antennae with a short terminal antennomere.

(3) Crown-group ant males: Antennae are filiform with similar segments, although in many cases the terminal segment is about 1.5 times longer than the others. In some cases, flagellomeres slightly increase in width and length towards the apex; in two cases (Leptogenys Roger, Platythyrea Roger), they diminish in length from F2/F3 towards the apex (the terminal flagellomere is again noticeably longer). Finally, in some genera (e.g., Myrmica Latreille) terminal flagellomeres are very long and wide, so antenna is clavate.

(4) Cretaceous ant males: The length and probably width of flagellomeres diminish towards the apex; the terminal flagellomere is not longer than the penultimate one. 
A comparison of the relative length of antennal parts. (1) The smallest scape length (relative to flagellum length) is found in the Cretaceous ant males, followed by the crown-group ant males, next the females of the Sphecomyrmini, Haidomyrmecini, and finally by the crown-group ant females. The relative scape length of the crown-group ant females is more than three times greater than that of the Sphecomyrmini, and two times greater than that of the Haidomyrmecini. Bolton (2003) provided a SL-to-FL ratio of $25 \%$ for the Sphecomyrminae, but the analysis conducted here shows the ratio of about $20 \%$ (Table S9).

(2) The pedicel of the crown-group ant females are approximately $20 \%$ longer than F1 and F2 (Table S16), but there are exceptions in which PL $<$ F1L and PL $=$ F1L (Table S2). F1L and F2L are equal statistically, but exceptions include F1L $>$ F2L and F1L $<$ F2L.

(3) The stem-group ant females, except for the Haidomyrmecini, and all males (both crown-group and Cretaceous) demonstrate a statistically significant pattern F1L $>$ PL $<$ F2L (Table S16). Moreover, the difference in length is often considerable: $\mathrm{PL}<\mathrm{F} 1 \mathrm{~L}$ three-seven times in the Cretaceous ant males, up to seven times in the crown-group ant males, two-three times in the Sphecomyrmini, Gerontoformica cretacica, Myanmyrma; PL $<$ F2L three-four times in the Cretaceous ant males, up to six times in the crown-group ant males, 1.5 times in G. cretacica and Myanmyrma, up to almost three times in the females of the Sphecomyrmini. The females show only three exceptions to the aforementioned pattern: $\mathrm{PL}=\mathrm{F} 2 \mathrm{~L}$ (Boltonimecia canadensis, Zigrasimecia ferox \#1), PL $>\mathrm{F} 2 \mathrm{~L}$ (G. occidentalis). More exceptions, including patterns PL>F1L, PL $>$ F2L, PL=F2L, are seen in the males (Table S3). The comparison of F1L and F2L shows that only in the Sphecomyrmini F1L $>$ F2L (without exception, and this pattern is confirmed statistically). In all other groups, F1L is not statistically different from F2L (Table S16). The greatest difference between F1L and F2L (up to two times) is found in the Sphecomyrmini, G. cretacica, Myanmyrma, Archaeopone taylori, Baikuris mandibularis, and some crown-group ant males.

(4) Unlike the Sphecomyrminae, but like the crown-group ant females, Boltonimecia demonstrates a pattern PL $>$ F1L. However, unlike the crown-group ant females, Boltonimecia also demonstrates patterns PL=F2L and F1L $<$ F2L (Table S2).

(5) The Haidomyrmecini is a heterogeneous group in terms of antennal metrics. They, unlike the crown-group ant females and Sphecomyrmini, did not show statistical differences between PL, F1L, F2L (Table S16), but show different patterns: in Haidomyrmex scimitarus and $H$. cerberus $\mathrm{PL}<\mathrm{F} 1 \mathrm{~L}$, in Haidoterminus cippus and Haidomyrmodes mammuthus $\mathrm{PL}=\mathrm{F} 1 \mathrm{~L}$, in Haidomyrmex zigrasi $\mathrm{PL}>\mathrm{F} 1 \mathrm{~L}$ (all differences are minor, except for Haidomyrmex scimitarus showing a two-fold difference), in Haidomyrmex zigrasi and Haidomyrmodes mammuthus $\mathrm{PL}=\mathrm{F} 2 \mathrm{~L}$; in Haidomyrmex scimitarus and $\mathrm{H}$. cerberus PL $<$ F2L (a considerable difference of two and four times respectively), in Haidoterminus cippus PL $>$ F2L, in Haidomyrmex scimitarus and $H$. cerberus F1L $<$ F2L (1.5- and two-fold differences respectively) $(H$. zigrasi also shows F1L<F2L but with minor difference), in Haidomyrmodes mammuthus $\mathrm{F} 1 \mathrm{~L}=\mathrm{F} 2 \mathrm{~L}$, in Haidoterminus cippus F1L >F2L (minor difference) (Table S2).

A comparison of male and female indices. (1) Scape. The means of two indices (SL/HL, SL/FL) of the Cretaceous ant males are lower than those of the females of Sphecomyrminae, while the means of the crown-group ant males are almost equal to those of the females of Sphecomyrminae. Rare exceptions include the crown-group ant males and Cretaceous ant males with large indices, which are as large as in the crown-group ant females (Tables S2, S3, S4, S9, S15).

(2) Flagellum. The means of FL/HL of the Cretaceous ant males and crown-group ant males are greater than those of the stem- and crown-group ant females (Tables S5, S15).

(3) Pedicel. All pedicellar indices of the males studied are not different from those of the females (Tables S6, S10, S15).

(4) The first and second segment of the flagellum. The patterns of these segments resemble the scape patterns: the indices of the crown-group ant males are similar to those of the females of Sphecomyrminae, and noticeably greater than those of the crown-group ant females. The largest indices are seen in the Cretaceous ant males (Tables S7, S8, S11, S12, S15).

(5) The correlation between HL and length of different antennal parts was weaker in the males $\left(\mathrm{R}^{2}\right.$ $=0.3-0.6)$, than in the females $\left(\mathrm{R}^{2}=0.5-0.8\right)$. The correlation between SL and FL was negligible in the males $\left(\mathrm{R}^{2}=0.02\right)$. 
General observations on the shape of the pedicel. A long pedicel must be narrowed towards the scape and bent at its base to facilitate the scape-pedicel-flagellum articulation. Almost all crown-group ant females have the pedicels of such a shape, even those whose pedicels are not longer than F2 and F3. Rare exceptions include some army ants: their pedicels are short, with an almost non-existent bent, but are triangular (i.e., with narrowed bases) as in all other ants. Likewise, in some specimens of Myrmecia and Nothomyrmecia Clark, the bent is almost non-existent, but the pedicel is always narrowed at the base. Crown-group ant males also have the pedicels mainly narrowed towards the scape and bent at the base, but the males with a short scape $(\mathrm{SL} / \mathrm{HL}<0.2)$ have barrel-shaped or spherical pedicels. Cretaceous males seem to demonstrate the same pattern: the only species with the scape index below 0.2 (Baikuris mandibularis) has a barrel-shaped pedicel, but all other Cretaceous males have triangular pedicels. All stem-group ant females have the scape index equal to or greater than 0.2 and so triangular pedicels. Thus, Dlussky and Fedoseeva's (1988) assumption about the unique shape of pedicels in Sphecomyrminae is erroneous.

A comparison of the antennal indices of female ants and female non-ant Aculeata. (1) SL/AL of the crown-group ants is greater than that of all Vespoidea and Apoidea listed in Dlussky and Fedoseeva (1988) (i.e., crown-group ants have the greatest relative scape length) (Fig. 5A). The second greatest mean is seen in the social Vespoidea and Apoidea. Interestingly, the lowest SL/AL of the crown-group ants (in the Pseudomyrmicinae, Dorylinae, Leptanillinae, Martialinae) is almost equal to the lowest SL/AL of the social non-ant Hymenoptera (Table S2). The stem-group ants have one of the lowest mean of this index, and the lowest absolute value. The ANOVA indicated that the means were significantly different $\left(\mathrm{F}_{4,109}=62.45, \mathrm{P}<0.0001\right)$. The planned comparisons showed that the differences between the crown-group ants and social Aculeata as well as between the stem-group ants and Vespoidea, Apoidea were negligible (Table S13). Thus, crown-group ants and other social Aculeata indeed underwent scape elongation (probably with simultaneous shortening of the flagellum), as was hypothesized by Dlussky (1983). These findings are the first statistical support in favor of Dlussky's hypothesis.

(2) The stem-group ants have the greatest AL/HL mean (Fig. 5B), and also the two greatest absolute values of this index (Table S2). The ANOVA showed that the means were significantly different $\left(\mathrm{F}_{4,109}=21.27 ; \mathrm{P}<0.0001\right)$, with statistically significant differences between all the groups, except for the difference between the crown-group ants and Vespoidea (Table S14).

Canonical discriminant analysis. This analysis based on the female indices SL/HL, FL/HL, F1L/HL, and F2L/HL was performed in order to achieve discrimination between crown- and stem-group ants. PL/HL was not used because it makes no contribution to the discrimination between the two groups; other unused indices are dependent on the aforementioned ones.

The first analysis was run with all the species. This approach explained $62 \%$ of the variation in the grouping variable (i.e., $62 \%$ of the species were correctly classified either as stem- or crown-group ants); on the other hand, the cross validated classification showed that $93 \%$ of the species were correctly classified (100\% of crown- and $72 \%$ of stem-group ants). The discriminant function equation was as follows:

$\mathrm{D}=(-0.73 \times \mathrm{SL} / \mathrm{HL})+(0.63 \times \mathrm{FL} / \mathrm{HL})+(7.40 \times \mathrm{F} 1 \mathrm{~L} / \mathrm{HL})+(1.88 \times \mathrm{F} 2 \mathrm{~L} / \mathrm{HL})-1.98$.

The mean discriminant scores (centroids): - 0.90 for crown-group ants, 1.90 for stem-group ants (Fig. $6 \mathrm{~A}$; Table S17). The cut-off score separating both groups was 0 . The discriminant function equation can be used to predict the group membership of newly discovered species by comparing the cut-off score, $\mathrm{D}$ and centroids. For example, three species described recently (Barden and Grimaldi 2016; Perrichot et al. 2016) have D scores 6.86 (Gerontoformica maraudera Barden and Grimaldi), 0.66 (Camelomecia janovitzi), and 2.75 (Ceratomyrmex ellenbergeri Perrichot, Wang and Engel) that classifies them as stem-group ants.

A better discrimination between the two groups can be achieved after the removal of the Haidomyrmecini because their discriminant scores overlap with the scores of the crown-group ants. This approach explained $72 \%$ of the variation and correctly classified $95 \%$ of the species $(98 \%$ of crown-, $80 \%$ of stem-group ants) (Fig. 6B; Table S17). The discriminant function equation was as follows:

$\mathrm{D}=(-0.63 \times \mathrm{SL} / \mathrm{HL})+(0.37 \times \mathrm{FL} / \mathrm{HL})+(15.24 \times \mathrm{F} 1 \mathrm{~L} / \mathrm{HL})+(-5.99 \times \mathrm{F} 2 \mathrm{~L} / \mathrm{HL})-1.85$.

The centroids: -0.98 for crown-, 2.6 for stem-group ants. The cut-off score was 0 . 
Summing up these findings, antennal morphometry seems to be a promising heuristic tool in the taxonomy of fossil ants, as there exists a statistical basis for discriminating between stem- and crowngroup ant females. The present research, however, should be viewed as preliminary, providing a basis for future studies when more stem-group species are discovered. New morphological data can be used in the model developed herein to confirm and extend its application.

\section{The higher classification of the ants}

There is little doubt that the higher classification of the Formicidae with well-diagnosed stem and crown taxa will be an important development towards an understanding of the origin and evolution of the ants (Ward 2007). But here, a number of complicating issues arise. First of all, we have to ask what ranks should be given to stem taxa, how we define the highest ranks of the Formicidae (in other words, what makes a subfamily a subfamily?), and finally, is it possible at all to apply the same classification principles to such different parts of the phylogenetic tree as crown and stem branches?

Obviously, even in modern groups, it is a challenge to find strong morphological characters of a subfamilial level. For example, a gastral constriction has been for a long time considered as such a character - it is one of the main characteristics of the Ponerinae in the old sense, or several subfamilies of the poneroids in the modern sense; but a gastral constriction is also present in the ectaheteromorphs, which have been assigned to the formicoid clade only after extensive molecular analyses (Brady et al. 2006; Moreau et al. 2006; Rabeling et al. 2008). The next example is a one- or two-segmented waist, which is a reliable subfamily-level character in some cases but variable in others (in the Dorylinae, Leptanillinae, Myrmeciinae).

Not surprisingly, the situation in stem-group ants is much more complicated, because the "weight" of a character decreases the farther we move down the evolutionary scale. For instance, it is possible that the presence of a gastral constriction is a genus-level character in the Sphecomyrminae, unlike crown-group ants, where it varies at a subfamilial level (discussed below). As Dlussky and Fedoseeva (1988) noted, the ancestors of all branches of the ant tree were probably so similar that, if they existed today, we would have assigned all of them to a single genus. This means that in ancestral groups, "strong" morphological characters could be not only vague but also combined in unusual ways.

Probably realizing that morphology is a poor tool for defining a taxon's rank, Hennig (1966) suggested that ranks could be associated with the absolute age of the taxa. If we check this assumption by the time needed to accumulate enough distinguishing characters, the following points can be outlined.

The youngest subfamilies of the crown clade are at least $70 \mathrm{Ma}$ old. For example, the dorylomorph clade represented by six subclades, which, until recently, had the status of subfamilies, but now are subsumed into a single subfamily (Dorylinae), is 74-101 Ma old (Brady et al. 2014). It is revealing that it took several decades of morphological studies to justify the split of the dorylomorphs into six subfamilies (Baroni Urbani et al. 1992; Bolton 2003; Brady and Ward 2005), and the first molecular data confirmed the split (Brady et al. 2006; Moreau et al. 2006; Rabeling et al. 2008); but deeper molecular research showed that this conclusion was erroneous (Brady et al. 2014). It seems plausible that an age greater than $70 \mathrm{Ma}$ is required for a group to be confidently recognized as an ant subfamily.

From this, only if the age of the Sphecomyrminae is about $150 \mathrm{Ma}$, and if the Sphecomyrminae survived until the end of the Cretaceous, their subfamily rank can be congruent with modern subfamilies (not taking into account the fact that the rate of evolutionary radiation of Cenozoic ants (i.e., crown-group ants) was higher than that of Mesozoic ants (mainly stem-group lineages) and thus the Sphecomyrminae probably required even more time to accumulate characters of a subfamilial "weight" than crown-group ants). But as inferred from fossil records, the Sphecomyrminae existed for only 20 Ma.

The inability to apply the same criteria for the classification of stem and crown groups raises the problem of a classification system. Indeed, in the Linnaean system, it is usually impossible to classify stem taxa, as only the taxa that are explicitly associated with ranks can be formally named (Ereshefsky 2001; Pleijel and Rouse 2003; Joyce et al. 2004). To give ants as an example, under the Linnaean system, stem clades and supra-subfamilial clades of the crown clade (e.g., formicoids, poneroids) can be named only if assigned to intermediate ranks, which will make the classification exceedingly complicated. 
Another problem is that the rank-based system implies comparability across taxa of the same rank, but in fact these taxa lack equivalency (Ereshevsky 2001), they are not comparable entities in a cladistic sense (Pleijel and Rouse 2003; Dubois 2007). If so, the ranks themselves are subjective devices, serving only to build classification; they are arbitrary and lack biological meaning (Hennig 1966).

The alternative of the Linnaean system is a rankless system such as the one governed by the PhyloCode (Cantino and de Queiroz 2010). Phylogenetic nomenclature of the PhyloCode extends the concept of tree thinking to biological nomenclature (Baum and Smith 2012) and, by classifying all organisms, not just descendants, helps, among other things, to explain the relationships between stem and crown branches.

To continue the example given above, rankless classification helps to clarify the status of the Sphecomyrminae. Their taxonomic status is indeed an unsolvable dilemma in the Linnaean system: although evidence of the long (at least $70 \mathrm{Ma}$ ) evolution of the Sphecomyrminae is absent, their phylogenetic level is expected to be higher than that of any modern subfamily. Since a stem taxon of a higher taxon is identical to that higher taxon (Hennig 1966), the Sphecomyrminae and other stem taxa can be viewed as sister groups to the crown clade; they are not comparable to the subfamilies of the crown clade but are equivalent to the crown clade as a whole.

Similarly, a phylogeny-based classification allows to place the Cretaceous representatives of crowngroup ants, for which using Linnaean ranks is also problematic, in particular clades. The statistical analysis of the antennal indices shows that Kyromyrma neffi, Canapone dentata, Eotapinoma macalpini, Chronomyrmex medicinehatensis, and Brownimecia clavata Grimaldi, Agosti and Carpenter undoubtedly belong to crown-group ants, but these first crown-group ants cannot be placed in any extant tribe; they are most probably stem taxa of extant subfamilies.

In a proposed higher classification of the ants, by using phylogenetic and Linnaean nomenclature together, I attempt to show how clades that are important for our understanding of ant evolution but are not explicitly associated with Linnaean ranks can be formally defined. I believe that the two systems should not be viewed as competitors, but instead as complementing each other.

\section{Crown-Formicidae}

Diagnosis (workers, gynes). (1) Scape long (SL/HL no less than 0.3, often more than 0.6; SL/ FL more than 0.3, often more than 0.5); (2) flagellomeres short (F1L/HL and F2L/HL less than 0.2, often less than 0.1 ) and whole flagellum short (FL/HL often < 1.4); (3) terminal flagellomere usually elongated; (4) PL often > F1L and > F2L (20\% on average); (5) F1L=F2L, middle flafellomeres often equal in length as well; (6) antenna clavate or at least flagellomeres gradually widening to apex; (7) mandibles broad, multidentate; (8) clypeus posteriorly inserted between antennal sockets or not; (9) two spurs of mesotibia and metatibia present or not; (10) preapical tooth on pretarsal claws present or not; (11) trochantellus absent; (12) waist one or two-segmented.

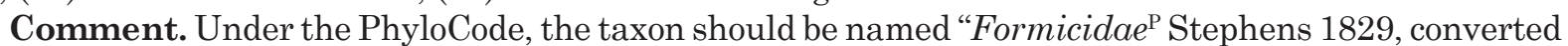
clade name" and defined as "the clade originating with the most recent common ancestor of Martialis heureka Rabeling and Verhaagh, 2008 and Formica rufa Linnaeus, 1761". This clade corresponds to the family Formicidae Latreille, 1809, excluding stem taxa.

Composition. The clade is monophyletic (Baroni Urbani et al. 1992; Brady et al. 2006), with estimates of diversity of more than 13000 species. The high-level classification of the Formicidae has been greatly revised by Bolton (2003) and then received further support from molecular phylogenies (Brady et al. 2006; Moreau et al. 2006; Rabeling et al. 2008). The composition of the subclades that correspond to 17 monophyletic subfamilies is stable (Ward 2011), but the clade structure above the subfamilial level is not well understood. It is believed that the clade splits into two major subclades: the formicoid clade (formicoids) and the poneroid clade (poneroids) (Ward 2007). The former is a stable clade, although its structure is different in morphological and molecular analyses; the latter is either a sister clade to the formicoids or a paraphyletic group from which the formicoids arose (Ward 2011).

Discussion. Formicidae ${ }^{\mathrm{P}}$ have antennae with three functional parts: a long scape, short middle part, elongated/thickened apical part. The scape comprises about $60 \%$ of the length of the flagellum (three times greater than in stem-group ants); the flagellum is about 1.3 times longer than the head (1.8 times in stem-group ants). 
The first Formicidae ${ }^{\mathrm{P}}$ are known from the Cretaceous: Kyromyrma neffi and Brownimecia clavata are from New Jersey amber (Turonian, $92 \mathrm{Ma}$ ); Eotapinoma macalpini, Chronomyrmex medicinehatensis, and Canapone dentata are from Canadian amber (Campanian, 78-79 Ma).

Brownimecia clavata almost certainly belongs to Formicidae $^{\mathrm{P}}$, but its position within the clade remains unclear. It may be a stem taxon of either the poneromorphs or the poneromorphs + leptanillomorphs (Bolton 2003), or even a stem taxon of a subfamily (such as the Amblyoponinae or Ponerinae). This species is not included in the statistical analysis due to its uncertain taxonomic position; however, Brownimecia's indices are close to the means for the crown-group ants, which at least confirms its affiliation with the crown clade.

The taxa for which placement (within or outside of Formicidae ${ }^{\mathrm{P}}$ ) is highly uncertain: Cananeuretus occidentalis, Burmomyrma rossi Dlussky, Formiciinae. C. occidentalis' (Aneuretinae) index SL/HL is close to the mean for the crown group, but the index PL/HL is more than twice greater than the greatest values in the stem- and crown-group ants, and more than four times greater than their means (Fig. 4D). It is not possible to calculate the other indices due to the incomplete preservation of the antennae. B. rossi is thought to be a stem group of the Aneuretinae (Dlussky 1996), but poor preservation makes this hard to confirm. The early Eocene (50 Ma) (Archibald et al. 2011) extinct subfamily Formiciinae was placed outside of the crown-group ants in the cladistic study of Baroni-Urbani et al. (1992) and Grimaldi et al. (1997). Those data should be interpreted with caution, because the Formiciinae are known only from poorly preserved imprints in rock. Their antennae are not preserved, so the Formiciinae were not included in the statistical analysis performed here.

\section{Pan-Formicidae}

Diagnosis (workers, gynes). Characters shared by crown-group ants (Formicidae ${ }^{\mathrm{P}}$ ) and stem-group ants: (1) wingless worker caste; (2) head prognathous; (3) metapleural gland present; (4) differentiated petiole present. Characters of crown-group ants $\left(\right.$ Formicidae $\left.^{\mathrm{P}}\right)$ : see Crown-Formicidae. Characters of stem-group ants: (1) scape short (SL/HL can be less than 0.3, rarely more than 0.6; SL/FL often less than 0.3 and never more than 0.5); (2) flagellomeres long (F1L/HL and F2L/HL > 0.1, often more than 0.2) and whole flagellum long (FL/HL > 1.4); (3) terminal flagellomere elongated or not; (4) often F1L $>$ PL $<$ F2L; (5) F1 longer, shorter, or equal in length to F2; (6) antenna without club, flagellomeres rarely widened/ elongated towards apex, may diminish in length towards apex; (7) mandibles narrow, linear bidentate or highly specialized (L-, scythe-shaped, cuplike) monodentate; (8) clypeus posteriorly usually not inserted between antennal sockets; (8) trochantellus present or not; (9) mesotibia and metatibia each with two spurs; (10) preapical tooth on pretarsal claws often present; (11) waist one-segmented.

Comment. Under the PhyloCode, the taxon should be named "Pan-Formicidae ${ }^{\mathrm{P}}$, new clade name" and defined as "the total clade composed of the crown clade Formicidae ${ }^{\mathrm{P}}$ and all extinct species that share a more recent common ancestor with Formicidae $^{\mathrm{P}}$ than with any extant species that are not members of Formicidae ${ }^{\mathrm{P}}$. Reference phylogenies: Grimaldi et al. 1997: Barden and Grimaldi 2016. More characters of crown-group ants are listed elsewhere (Bolton 2003; Boudinot 2015).

Composition. Formicidae ${ }^{\mathrm{P}}$, Sphecomyrminae ${ }^{\mathrm{P}}$.

Discussion. In stem-group ants, unlike crown-group ants, the antenna is not divided into three functional parts; usually there is no striking difference between the length of the scape and flagellomeres; the antennal club is absent.

The taxa (genera) which definitely belong to Pan-Formicidae ${ }^{\mathrm{P}}$ but whose position within the clade remains unclear: Archaeopone Dlussky, Baikuris Dlussky, Dlusskyidris Bolton, Poneropterus Dlussky, Myanmyrma Engel and Grimaldi, Camelomecia Barden and Grimaldi. The first four genera are known from males only. Myanmyrma (as well as some species of Gerontoformica - see below) may represent a separate clade of Pan-Formicidae ${ }^{\mathrm{P}}$. Myanmyrma's indices are strongly different from those of the crown group. SL/HL is close to that of the Sphecomyrmini, but SL/AL is the lowest of all Aculeata species considered in the present study (i.e., Myanmyra has one of the shortest scapes). Regarding other antennal parts, Myanmyrma is also unique: it has the longest pedicel, F1, F2, and one of the longest flagella. Other unique characters include extremely elongated mandibles, a bilobate clypeal margin, and long genal process (all are putative apomorphies). The "poneroid" habitus of Myanmyrma (Engel and Grimaldi 2005) is questionable; its deep gastral constriction, implying a morphologically differentiated 
postpetiole (unknown in stem-group ants), may be an artifact. Thus, it is safe to discard the assumption that Myanmyrma belongs to crown-group ants (Engel and Grimaldi 2005). All the evidences indicate that Myanmyrma is a stem-group species, showing a unique combination of characters. The same may apply to the recently described Camelomecia (Barden and Grimaldi 2016).

\section{Subfamily Sphecomyrminae Wilson and Brown 1967}

Composition. Tribes Sphecomyrmini, Haidomyrmecini, Zigrasimeciini.

Discussion. It has been assumed that the Sphecomyrminae is a group close to the formicoid clade of the crown group (Taylor 1978; Rabeling et al. 2008). The Sphecomyrminae do indeed resemble representatives of the formicoid clade by the habitus, the presence of ocelli, and an unspecialized (though only in the Sphecomyrmini) head capsule similar to that of primitive formicines (Prolasius Forel, Notoncus Emery, Prenolepis Mayr) (Wilson et al. 1967). However, the data presented here suggest that the Sphecomyrminae is a stem clade, i.e., a sister group to the crown clade.

The clade is doubtfully monophyletic. The three subclades (tribes) may represent an artificial assemblage, although the Sphecomyrmini and Zigrasimeciini do seem closely related. Some important characters appeared to be variable. For example, scape length in Sphecomyrminae comprises $20 \%$ of flagellum length, compared with $60 \%$ in the crown group, and varies in a large range (discussed below). Other variable characters include the presence of the gastral constriction, trochantellus, and clypeal peg-like setae.

\section{Tribe Sphecomyrmini Wilson and Brown, 1967}

Diagnosis (workers, gynes). (1) head capsule unspecialized; (2) mandibles unspecialized; (3) anterolateral clypeal margins not produced over mandibular bases in rounded lobes; (4) peg-like setae on anterior clypeal margin present or not; (5) ocelli present; (6) F1L $>$ PL $<$ F2L, F1L $>$ F2L; F1 often longest flagellomere; (7) neck short or long; (8) petiole subsessile or pedunculate; (9) gastral constriction present or not.

Comment. Under the PhyloCode, the taxon should be named "Sphecomyrmini", converted clade name" and defined as "the clade consisting of Sphecomyrma freyi Wilson and Brown, 1967 and all species that share a more recent common ancestor with Sphecomyrma freyi Wilson and Brown, 1967 than with Haidomyrmex cerberus Dlussky, 1996 or Zigrasimecia Barden and Grimaldi, 2013”.

Composition. Genera Sphecomyrma Wilson and Brown (type genus), 1967, Cretomyrma Dlussky, 1975, Armania Dlussky, 1983, Pseudarmania Dlussky, 1983, Orapia Dlussky, Brothers and Rasnitsyn, 2004, Gerontoformica Nel and Perrault, 2004.

Discussion. The species of this tribe seem to be less specialized than those of the other two tribes of the Sphecomyrminae. Also, the tribe is heterogeneous due to the presence of possibly non-monophyletic genera Sphecomyrma and Gerontoformica.

In the genus Sphecomyrma, the SL/HL index has an unusually large range. Even in a single species, $S$. freyi, values range from 0.28 to 0.62 (Table S2), i.e., the difference is $120 \%$. Data on 11 modern genera (Radchenko 1991, 1994; Seifert 1992, 2000, 2003; MacKay 1993; Radchenko and Elmes 1998, 2003; Ward 1999; Radchenko et al. 2002; Baroni Urbani and de Andrade 2003; Wild 2004; Bolton 2007; Bolton and Fisher 2011) show that the range of the SL/HL among workers, gynes, and workers + gynes within a given species rarely exceeds $10 \%$, with a single maximum of $20 \%$ in Myrmica (Radchenko 1994), 31 \% in Linepithema Mayr (Wild 2004), 31 \% in Dolichoderus Lund (MacKay 1993). Such results raise the possibility that $S$. freyi $\# 3$, which has the SL/HL value of 0.28 , does not belong to Sphecomyrma.

Regarding the variation of the SL/HL index within a genus, the findings are the following. In the Cretaceous ant males as exemplified by Baikuris, the range is $77 \%$; in the workers of Sphecomyrma, it is $160 \%$ (or $106 \%$ if the clypeal lobe of $S$. mesaki is excluded). In modern genera, males are characterized by a large range: 100 \% in Proceratium Roger (Baroni Urbani and de Andrade 2003), $204 \%$ in Dolichoderus (MacKay 1993), 175\% (Seifert 1988) and $260 \%$ (Radchenko 1994) in Myrmica. The workers and gynes of modern genera range from $30 \%$ in Pseudomyrmex Lund to $55 \%$ in Proceratium (Seifert 1992, 2000, 2003; Radchenko 1994; Ward 1999; Baroni Urbani and de Andrade 2003; Bolton and Fisher 2011); only in the Dolichoderinae are there single large values, causing larger ranges up 
to $128 \%$ in Dolichoderus (MacKay 1993), and $121 \%$ in Technomyrmex Mayr (Bolton 2007). Therefore, whereas the range in Baikuris is consistent with the data on recent genera, the range in Sphecomyrma is not. Although the limits of within-genus variation are not known for Cretaceous representatives, taking into account the unique morphology of $S$. mesaki (short scape, antennal scrobes), its taxonomic position should also be re-examined.

The genus Gerontoformica, which includes 13 species, is even more problematic. Indeed, Gerontoformica is variable in generic- and higher-level characters, such as the scape length, palp formula, the presence of a petiolar peduncle, ocelli, gastral constriction, and trochantellus. In some species, the head seems to be specialized as in the Zigrasimeciini (frontal part thickened, anterolateral clypeal lobes present). All the species have peg-like setae on the anterior clypeal margin, again as in the Zigrasimeciini. The SL/HL index ranges from 0.19 (the minimum value obtained in this study) to 0.67 (one of the highest values of all stem-group ants) (Table S2), i.e., the difference is $250 \%$, which is larger than any within-genus range obtained here.

Gerontoformica and Sphecomyrmodes Engel and Grimaldi have recently been synonymized (Barden and Grimaldi 2016), which made the genus even more heterogeneous. Of special interest is the species $G$. cretacica, transferred from incertae sedis. In terms of the results of the statistical analysis, $G$. cretacica occupies an intermediate position between the crown- and stem-group ants. For SL/HL, $G$. cretacica is similar to the crown-group ants; its scape is the longest of all stem-group ants known, but its flagellum is also elongated proportionally to the scape, and thus the indices FL/HL and AL/HL are among the largest reported. The same applies to the pedicel, F1 and F2. Other interesting features are: the terminal flagellomere is not elongated (a rare character also found in two species of the Haidomyrmecini), antenna without the club, flagellomeres diminish in length towards the apex (Nel et al. 2004).

It is possible that Gerontoformica can be split into several genera, and these genera can be placed in different tribes within the Sphecomyrminae. But G. cretacica may fall out of Sphecomyrminae ${ }^{\mathrm{P}}$; its unique combination of characters (if it is not an artifact of preservation as suggested by the latest report (Barden and Grimaldi 2016)) may indicate that it is a representative of a subclade of Pan-Formicidae ${ }^{\mathrm{P}}$ branched close to the crown clade.

The problem of large within-genus variation of the scape length seen in Sphecomyrma and Gerontoformica may have, however, another angle. There is a long-lasting debate on whether stem-group ants were eusocial or not, and, as it was already pointed out, the answer to this question is probably linked to the problem of scape elongation (Dlussky 1983; Dlussky and Fedoseeva 1988). It is reasonable to assume that the transition to eusociality did not occur instantly but gradually, via the stage of facultative sociality, i.e., social behavior in stem-group ants depended on, for example, abiotic environmental conditions and varied even among closely related species. A similar pattern of social organization is found in the modern halictine bees (Yanega 1997). If this is the case, then the scape length was not stable in stem lineages.

Lastly, I will review the taxonomic status of the Armaniinae, an enigmatic group known mainly from winged forms preserved as imprints in rock. Dlussky initially assigned all his new Cretaceous species to the Sphecomyrminae (Dlussky 1975) but then transferred to the new family Armaniidae (Dlussky 1983). Wilson returned them to the Sphecomyrminae, and synonimized almost all genera of the Armaniinae (except Cretomyrma) with the genus Sphecomyrma (Wilson 1987). Bolton changed the status of Dlussky's family to the subfamily Armaniinae (Bolton 1994, 2003); Dlussky first accepted Bolton's approach (Dlussky 1996) but then again called the group Armaniidae (Dlussky 1999b), and then again mentioned the subfamily Armaniinae (Dlussky et al. 2004). In 2005, Wilson mentioned this group as the family Armaniidae (Wilson and Hölldobler 2005). Such confusion is caused by the absence of reliable characters distinguishing the Armaniinae from the other groups, especially from the Sphecomyrminae.

The gastral constriction is one of the most confusing characters. For example, Dolichomyrma was described without (Dlussky 1975) or with (Wilson 1987) the gastral constriction; Armania - with (Dlussky 1983) or without (Wilson 1987); Arhaeopone - with (Dlussky 1975) or without (Dlussky 1983); Petropone most probably has the gastral constriction (Dlussky 1975). It is now clear, however, that the gastral constriction is not a stable character in Sphecomyrminae, being present in some genera and absent in others. The trochantellus may be an important character distinguishing the Armaniinae and 
Sphecomyrminae (Dlussky 1983), but it not stable either, being variable even within a genus (e.g., in Gerontoformica) (Barden and Grimaldi 2014).

Also, the Armaniinae are characterized by a "very short scape", in contrast to just a "short scape" of the Sphecomyrminae (Bolton 2003). This is viewed as one of the most important diagnostic characters of the Armaniinae (Dlussky 1983). However, as can be seen from the statistical analysis, the scape indices as well as other antennal indices of the Armaniinae are not at all different from those of the Sphecomyrminae or Sphecomyrmini (Tables S2, S4-S8; Fig. 4). To give more support to these findings, I compared within-subfamily ranges of the scape index SL/HL in workers. The difference between the extreme values was the following: 3.5 times in the Sphecomyrminae (between Gerontoformica orientalis and G. rugosus); 2.2 times in the Ponerinae (from 0.53 in Feroponera Bolton and Fisher to 1.16 in Diacamma Mayr) (Shattuck and Barnett 2006; Bolton and Fisher 2008); 3.4 times in the Dolichoderinae (from 0.65 in Anillidris Santschi to 2.3 in Leptomyrmex) (Shattuck 1992; Lucky and Ward 2010; Schmidt et al. 2013); 4.6 times in the Myrmicinae (from 0.28 in Metapone Forel to 1.3 in Aphaenogaster Mayr) (Alpert 2007; Shattuck 2008); 6.2 times in the Formicinae (from 0.34 in Cladomyrma Wheeler to 2.13 in Euprenolepis Emery) (Agosti et al. 1999; LaPolla 2009). The difference observed between the Armaniinae and Sphecomyrminae is much lower than these values (Table S4). Thus, even in comparison with diverse modern groups, the Sphecomyrmini and Armaniinae can be viewed as one homogeneous entity.

Another important feature listed in the diagnosis of the Armaniinae is the shape of the petiole. In the Armaniinae, the petiole is broadly attached posteriorly to the gaster, which resembles the petiole of non-ant Vespoidea (e.g., Sierolomorphidae), while in the Sphecomyrminae it is nodiform (Dlussky 1999b). This may be the only remaining argument against changing the taxonomic status of the Armaniidae/Armaniinae, because such an attachment is unique and obviously plesiomorphic.

The drawings and photos of the Armaniinae, however, do not speak in favor of this conclusion. For example, in Orapia, Pseudoarmania, Armania curiosa the petiole looks rounded above and on the sides, not different from the petiole of the Sphecomyrminae. In the putative males of the Armaniinae (genera Archaeopone and Poneropterus), the petiole is massive but again similar to that of the putative males of the Sphecomyrminae (Sphecomyrma and Dlusskyridris). From the poorly preserved imprints of Khetania, Armania pristina, and A. capitata, one may conclude that the petiole does not appear to be differentiated from the gaster, which raises the question about the assignation of these specimens to the ants.

The only exception is a well-preserved imprint of Armania robusta with a relatively massive petiole, which seems, indeed, to be broadly attached to the gaster (although partly hidden by a coxa). Interestingly, Wilson (1987) considered this particular specimen as a gyne of Sphecomyrma, and its massive petiole as a sexually dimorphic feature, i.e., not as a subfamilial or even species-level character. Taking into account that there is no definition of a "broad attachment", it is necessary to fill this gap by calculating the index $\mathrm{PG} / \mathrm{PH}$ in the $A$. robusta holotype as well as in several species of stem- and crown-group ants. The values of this index in the ants with a nodiform petiole are the following: 0.5 (Gerontoformica subcuspis), 0.6 (Sphecomyrma freyi), 0.7 (Boltonimecia and gynes of Leptanilla). The larger value 0.8 (indicating that the petiole is more broadly attached to the gaster) is found in A. robusta; but in the workers and gynes of Stigmatomma (Amblyoponinae) values vary from 0.7 to 0.9. It is therefore impossible to reach the unambiguous conclusion that the petiole of $A$. robusta is a unique feature in terms of the width of its attachment to the gaster.

In summary, it is hard to disagree with Wilson (1987) that the Armaniinae do not have any subfamilial-level feature, to say nothing of a familial one. So my interpretation of the taxonomic status of the Armaniinae is similar to that of Grimaldi et al. (1997). Relatively well-preserved genera used in the statistical analysis (Armania, Pseudoarmania, Orapia) were transferred to Sphecomyrmini ${ }^{\mathrm{P}}$. All the other genera were considered to be groups of uncertain taxonomic position within Formicidae or $^{\mathrm{P}}$ Aculeata.

\section{Tribe Haidomyrmecini Bolton, 2003}

Diagnosis (workers, gynes). (1) head capsule specialized: face and genae concave, clypeus modified (putative apomorphy); (2) mandibles long, scythe or L-shaped (putative apomorphy); (3) anterolateral 
clypeal margins not produced over mandibular bases in rounded lobes; (4) peg-like setae on anterior clypeal margin absent; (5) ocelli present or not; (6) relative length of antennomeres variable; (7) terminal flagellomere elongated or not; (8) neck long; (9) petiole pedunculate; (10) gastral constriction present or not.

Comment. Under the PhyloCode, the taxon should be named "Haidomyrmecini", converted clade name" and defined as "the clade consisting of Haidomyrmex cerberus Dlussky, 1996 and all species that share a more recent common ancestor with Haidomyrmex cerberus Dlussky, 1996 than with Sphecomyrma freyi Wilson and Brown, 1967 or Zigrasimecia Barden and Grimaldi, 2013”.

Composition. Genera Haidomyrmex Dlussky, 1996 (type genus), Haidomyrmodes Perrichot, Nel, Néraudeau, Lacau, Guyotet, 2008, Haidoterminus McKellar, Glasier and Engel, 2013, Ceratomyrmex Perrichot, Wang and Engel, 2016.

Discussion. This group is morphologically compact, and readily distinguishable from the other stem taxa. The unique head and mandibles are the most important morphological features, but some findings from the statistical analysis are also noteworthy. The scape indices as well as the index F1L/ HL occupy an intermediate position between the Sphecomyrmini and crown-group ants. This negatively influenced the discrimination between stem- and crown-group ants in the canonical discriminant analysis, as well as limits the potential of antennal metrics for providing a more rigorous diagnosis of Pan-Formicidae ${ }^{\mathrm{P}}$. All the other indices are statistically similar to those of the Sphecomyrmini. Unlike the Sphecomyrmini, there is no pattern $\mathrm{F} 1 \mathrm{~L}>\mathrm{P}<\mathrm{F} 2 \mathrm{~L}$ (many exceptions); however, some patterns in a F1-to-F2 ratio can be noted at the generic level: Haidomyrmex - F2L $>$ F1L, Haidomyrmodes - F2L=F1L, Haidoterminus and Ceratomyrmex - F1L > F2L.

The presence of the gastral constriction in the Haidomyrmecini is questionable. Haidomyrmodes has been described with the gastral constriction, but it may be an artifact of preservation. It is also possible that this character is variable at the generic level, as in the Sphecomyrmini.

\section{Tribe Zigrasimeciini trib.n.}

Diagnosis (workers). (1) head capsule specialized: shield-like, with dorsal part thick and raised (putative apomorphy); (2) anterolateral clypeal margins produced over mandibular bases in rounded lobes (putative apomorphy); (3) peg-like setae on anterior clypeal margin present; (4) ocelli absent; (5) relative length of antennomeres variable; (6) neck long; (7) protibia with three spurs: one pectinate and two simple; (8) petiole pedunculate; (9) gastral constriction absent.

Comment. Under the PhyloCode, the taxon should be named "Zigrasimeciini ${ }^{\mathrm{P}}$, new clade name" and defined as "the clade consisting of Zigrasimecia Barden and Grimaldi and all species that share a more recent common ancestor with Zigrasimecia Barden and Grimaldi than with Sphecomyrma freyi Wilson and Brown, 1967 or Haidomyrmex cerberus Dlussky, 1996".

Composition. Genera Zigrasimecia Barden and Grimaldi, 2013 (type genus), Boltonimecia gen.n..

Discussion. A short scape, long flagellum, two spurs on meso- and metatibia, pretarsal claws with a preapical tooth, and the clypeus posteriorly not inserted between the antennal sockets indicate that Boltonimecia belongs to stem-group ants and the Sphecomyrminae. The only problem here is the form of the metapleural gland orifice and the presence of the mesoscutum and scutellum; these characters have been listed in the diagnosis of the Sphecomyrminae (Bolton 2003), but cannot be observed in Boltonimecia due to compression of the mesosoma.

The antennal indices of Boltonimecia and Zigracimecia (type species: Z. tonsora) are similar to those of the Sphecomyrmini, although some important peculiarities need to be mentioned. Boltonimecia's SL/ $\mathrm{HL}$ is one of the greatest among the Sphecomyrminae and is close to that of the crown-group ants. Both genera have a longer pedicel compared with the Sphecomyrmini; in Boltonimecia, the pedicel is so elongated that PL $>$ F1L, as in the crown-group ants (Sphecomyrmini always have F1L $>$ PL). In Boltonimecia and $Z$. ferox\#1, PL=F2L (in Sphecomyrmini, PL<F2L, except for Gerontoformica occidentalis). Also, in Boltonimecia, F1L<F2L (in Sphecomyrmini, F1L $>$ F2L without exception).

Therefore, the statistical analysis also leaves no doubt about the assignation of Boltonimecia and Zigrasimecia to stem-group ants and the Sphecomyrminae. These two genera, however, seem to be closer to each other than to the Sphecomyrmini, thus I propose that they be placed into a separate tribe. 
The shield-like head, anterolateral clypeal margins produced over mandibular bases in rounded lobes, and three protibial spurs are the most important characters of the new tribe. Noteworthy, these are found also in some Gerontoformica species (Barden and Grimaldi 2014). In particular, the rounded anterolateral clypeal margins are present in G. spiralis and G. tendir; three protibial spurs (called "stiff setae" by the authors) - in G. spiralis, G. subcuspis, G. magnus, G. rubustus; at least some Gerontoformica have the shield-like head. Also, like Zigrasimeciini, G. rugosus and G. spiralis have a very long pedicel; all Gerontoformica have the peg-like setae on the anterior clypeal margin. These peculiarities are starting points for a thorough revision of a seemingly non-monophyletic genus Gerontoformica, which hopefully will be achieved in the near future.

\section{Subclades of Formicidae ${ }^{\mathrm{P}}$}

The last part of a proposed higher classification is the subclade composition of the crown group Formicidae $^{\mathrm{P}}$. Since the composition of the subclades that correspond to monophyletic subfamilies is stable, a phylogeny-based classification is straightforward and congruent with the Linnaean system. In a formal phylogenetic definition of the subclades given in Table S18, attention was paid to the recommendation that the type species (Article 11.7 of the PhyloCode) and the species used in the reference phylogenies (Article 11.8 of the PhyloCode) should preferably be used as specifiers. For most of the clades, a node-based definition is used, except for the clades consisting of only one extant species, for which a branch-based definition is provided.

The vast majority of Cenozoic fossil crown-group ants fit nicely into the clades that correspond to tribes or genera in the Linnaean system; some Cretaceous crown-group species (Brownimecia) are most probably stem taxa to a clade of a higher (supra-subfamilial) taxonomic level; and only a few fossil crown-group species are related to modern subfamilies but do not fall into any of the tribes (i.e., they are stem taxa to those subfamilies). Most likely, only five taxa (genera) can be considered as forming pan-clades with three recent subfamilies, a formal definition of which is provided below (diagnoses after Bolton (2003), with modifications).

\section{Pan-Formicinae}

Diagnosis (workers, gynes). (1) acidopore present at apex of hypopygium (apomorphy); (2) sting absent; (3) helcium attached low on anterior face of first gastral segment.

Comment. Under the PhyloCode, the taxon should be named "Pan-Formicinae ${ }^{\mathrm{P}}$, new clade name" and defined as "the total clade composed of the crown clade Formicinae ${ }^{\mathrm{P}}$ and all extinct species that share a more recent common ancestor with Formicinae $^{\mathrm{P}}$ than with any extant species that are not members of Formicinae"

Composition. Formicinae ${ }^{\mathrm{P}}$, Kyromyrma Grimaldi and Agosti, 2000.

Discussion. Kyromyrma has a generalised morphology (Grimaldi and Agosti 2000) and thus cannot belong to any recent tribe. It has been assumed that Kyromyrma is a representative of stem formicines (Ward 2007), i.e., belongs to the clade Pan-Formicinae ${ }^{\mathrm{P}}$. Given that the crown group Formicinae ${ }^{\mathrm{P}}$ arose around $80 \mathrm{Ma}$ ago (Brady et al. 2006), the age of Kyromyrma (92 Ma) is consistent with this assumption.

\section{Pan-Dolichoderinae}

Diagnosis (workers, gynes). (1) junction of pygidium and hypopygium slit-like (apomorphy); (2) sting vestigial; (3) helcium attached low on anterior face of first gastral segment.

Comment. Under the PhyloCode, the taxon should be named "Pan-Dolichoderinae ${ }^{\mathrm{P}}$, new clade name" and defined as "the total clade composed of the crown clade Dolichoderinae $e^{\mathrm{P}}$ and all extinct species that share a more recent common ancestor with Dolichoderinae ${ }^{\mathrm{P}}$ than with any extant species that are not members of Dolichoderinae ${ }^{\mathrm{P}}$.

Composition. Dolichoderinae ${ }^{\mathrm{P}}$, Eotapinoma Dlussky, 1988, Zherichinius Dlussky, 1988, Chronomyrmex McKellar, Glasier and Engel, 2013. 
Discussion. Eotapinoma (Sakhalin and Canadian amber) looks much like representatives of the tribe Tapinomini; but the species from Sakhalin amber (Dlussky 1988) are poorly preserved, and the one from Canadian amber (Dlussky 1999a) was described briefly and is now lost. Dlussky also noted that Eotapinoma and Zherichinius (Sakhalin amber) have similarities with both the Dolichoderinae and Formicinae (Dlussky 1988, 1999a). However, there is now little doubt that both genera are stem dolichoderines (Ward et al. 2010). One cannot also reject the possibility that Zherichinius is a crown dolichoderine (Dolichoderinae ${ }^{\mathrm{P}}$ ), since the latter arose around 60-67 Ma ago (Ward et al. 2010) and thus can in principle be present in Sakhalin amber, which is 43-47 Ma old (Radchenko and Perkovsky 2016).

Chronomyrmex (Canadian amber) initially was placed in the tribe Leptomyrmecini (McKellar et al. 2013a). However, the Leptomyrmecini is a morphologically heterogeneous assemblage, recognized primarily by disagreement with the three other tribes (Ward et al. 2010), and thus it is obvious that Chronomyrmex simply lacks the characters of the other tribes. Taking into account the time of its emergence, Chronomyrmex cannot belong to the crown dolichoderines (and as a result, to any recent dolichoderine tribe); it is a stem taxon to the Dolichoderinae, or, less probably, to all dolichoderomorphs (Dolichoderinae+Aneuretinae).

\section{Pan-Ectatomminae}

Diagnosis (workers, gynes). (1) clypeus broadly inserted between frontal lobes; (2) outer margins of frontal lobes not pinched in posteriorly; (3) helcium projects from about midheight of anterior face of abdominal segment III; no high vertical anterior face to abdominal segment III above helcium.

Comment. Under the PhyloCode, the taxon should be named "Pan-Ectatomminae ${ }^{\mathrm{P}}$, new clade name" and defined as "the total clade composed of the crown clade Ectatomminae $e^{\mathrm{P}}$ and all extinct species that share a more recent common ancestor with Ectatomminae ${ }^{\mathrm{P}}$ than with any extant species that are not members of Ectatomminae $\mathrm{p}^{\mathrm{p}}$.

Composition. Ectatomminae ${ }^{\mathrm{P}}$, Canapone Dlussky, 1999.

Discussion. The first and second diagnostic characters are putative, as the morphology of the anterodorsal part of the head in Canapone (Canadian amber) is unknown, and the holotype is now lost. Canapone initially was placed in the Ponerinae (Dlussky 1999a) and then transferred to the Ectatomminae incertae sedis (Bolton 2003). It is likely that Canapone is closest to the Ectatomminae, but cannot be placed in any recent ectatommine tribe, as it is unique in having plesiomorphies that have been lost by extant species (Bolton 2003).

\section{Aculeata incertae sedis}

Genera. Cretopone Dlussky, 1975, Dolichomyrma Dlussky, 1975, Khetania Dlussky, 1999, Petropone Dlussky, 1975.

Discussion. Cretopone, Petropone, and Khetania are poorly preserved. It is hard to disagree with Grimaldi et al.'s (1997) conclusion that the first two genera do not have ant synapomorphies. Khetania does not have ant synapomorphies either; its petiole is not well defined, the antennae are not preserved. Dolichomyrma is remarkable for its small size $(3-5 \mathrm{~mm})$ and the absence of wings, as in worker ants. The petiole of Dolichomyrma is nodeless, which is why Dlussky initially believed it was a dolichoderine or specialized sphecomyrmine (Dlussky 1975), but then placed it in the Armaniidae (Dlussky 1983). I am proposing that Dolichomyrma be placed into the Aculeata incertae sedis, because it does not have ant synapomorphies, and its petiole is similar to that of some Bethylidae.

\section{Conclusion: the origin and evolution of ants}

Fifty years ago, Wilson et al. (1967) discovered Cretaceous Sphecomyrma, a primitive ant with plesiomorphic characters, claimed to be the ancestor either of one of the two branches of the ant lineage (Wilson et al. 1967) or all living ants (Taylor 1978). Since then, other ants, some $10 \mathrm{Ma}$ older than Sphecomyrma, have been discovered. It has become evident that Cretaceous stem-group ants were 
not only very diverse but also very specialized. Furthermore, if primitive stem lineages had coexisted with crown-group ants, such as Kyromyrma, Canapone, Eotapinoma, Brownimecia, then the former cannot be the direct ancestors of the latter. There is now general agreement that stem groups like the Sphecomyrminae are the result of the primary diversification in the ant tree, and so the true ancestor of both stem- and crown-group ants has to have existed before them.

Currently, however, there is no consensus of opinion on what that ancestor was like. Wheeler (1926) proposed that the genus Myzinum (Tiphiidae) is closest to the ants; Wilson et al. (1967) concurred about Tiphiidae but chose the genus Methocha Latreille. Dlussky and Fedoseeva (1988) argued that groups with wingless females cannot be ant ancestors because this leaves unexplained the secondary emergence of wings in ants. After the rise of cladistics and introduction of the methods of molecular systematics, the issue became no less clear. The first morphological cladistic study by Brothers (1999) showed the sister group of ants to be Vespidae + Scoliidae. A DNA study of the Hymenoptera (Heraty et al. 2011) suggested that the sister groups of ants is either Mutillidae + Sapygidae + Tiphiidae + Bradynobaenidae + Pompilidae + Scoliidae or Sphecidae + Scoliidae. Another study (Peters et al. 2011) revealed it to be either Vespidae + Mutillidae + Bradynobaenidae + Bethylidae + Pompilidae or Tiphidae. A study combining molecular and morphological data of the Vespoidea (Pilgrim et al. 2008) showed it is either Sapygidae + Bradynobaenidae or Vespidae + Rhopalostomatidae. Finally, a phylogenomic study (Johnson et al. 2013) based on the genomes and transcriptomes of 11 species of the Aculeata unexpectedly concluded that ants are closer to the Apoidea, not to Vespoidea.

Most of the presently known stem-group ants are thought to have had an arboreal lifestyle - they have long legs and are preserved in amber, ancient tree resin. On the other hand, most primitive extant ants (Martialinae, Leptanillinae, poneroids) are small cryptic subterranean species. These groups could indeed have evolved from above-ground ancestors, but since the general trend of ant morphological evolution suggests otherwise, there is some reason to think that their ancestors were cryptic as well. The increased mobility of the gaster, with the resulting separation of the petiole, likely suggests an adaptation to an underground lifestyle. This type of adaptation is also recognizable in the emergence of the metapleural gland, which has a role in defense against parasites in underground colonies (Yek and Mueller 2011). Therefore, if the first ants were underground (Lucky et al. 2013), then the Martialinae and other primitive forms may be viewed as relicts that have changed little during evolution as a result of living in ecologically stable habitats (Rabeling et al. 2008).

Finding paleontological records of the subterranean ant ancestors is a significant challenge. The reasons are: (1) that these ants are doubtfully preserved in amber due to their cryptic lifestyle (for example, ants are unknown in Early Cretaceous ambers (LaPolla et al. 2013) such as Spanish and Lebanese), (2) that their number was too small to be occasionally trapped in amber (ants comprise only $0.001-0.05 \%$ of all insects preserved in Late Cretaceous ambers (Grimaldi and Agosti 2000), so the number of ants in earlier ambers is even lower), and (3) that they were too small to be preserved as imprints in rock (however, ichnofossils, such as those from the Upper Jurassic Morrison Formation dated at 156-146 Ma (Hasiotis and Demko 1996), may actually be traces of these ants).

When considering factors underlying ants' extraordinary evolutionary success, phenotypic plasticity and ecological niche construction have to be named first. The former is the capacity of a single genotype to exhibit variable phenotypes - behavioral, biochemical, physiological, developmental - in different environments (West-Eberhard 2003; Pigliucci et al. 2006). It is now viewed as a widespread phenomenon that can facilitate evolutionary change and speciation (Price et al. 2003). One example of ants' phenotypic plasticity in action is caste polyphenism responsible for their diverse ecological adaptation (Simpson et al. 2011). The second factor, niche construction, signifies the alteration of the environment that then affects selection pressures. Odling-Smee et al. (2003) claimed that niche construction "should be regarded, after natural selection, as a second major participant in evolution". The importance of ant niche construction is difficult to overestimate, as ants are among the most active ecosystem engineers (Folgarait 1998).

Given the aforementioned ideas, the main steps in ant evolution can be now outlined. The first ants, which may have originated as early as the Upper Jurassic, were solitary underground species. During the Late Cretaceous, about $100 \mathrm{Ma}$ ago, they underwent diversification, evolved a nuptial flight and arboreal lifestyle, either become eusocial or were at the stage of facultative sociality. The common ancestor of crown-group ants lived about $123 \mathrm{Ma}$ (from 141 to $116 \mathrm{Ma}$ ) ago (Brady et al. 2006; Schmidt 
2013); thus stem- and crown-group ants had existed alongside one another throughout the Cretaceous period, undergoing spectacular speciation in the first angiosperm forests (Moreau et al. 2006).

There was the transformation of terrestrial ecosystems after the major biotic extinction event at the end of the Mesozoic, during which about $50 \%$ of genera and $75 \%$ of plant and animal species became extinct (Jablonski and Chaloner 1994). Arboreal species were probably most vulnerable at that time and thereby doomed. Only some ants that now compose the crown clade have survived and successfully crossed the K/Pg boundary. They then occupied vacant niches of above-ground and arboreal predators and also began to actively make new ecological niches, thus preparing their own huge evolutionary success.

From this view, the evolutionary destiny of ants is similar to the one of mammals which occupied new niches after the extinction of large reptiles. During Cenozoic time, both groups have undergone remarkable adaptive radiation; in the invertebrate micro-world and vertebrate macro-world respectively, they became successful terrestrial predators, largely thanks to phenotypic plasticity, brood care and complex social behavior.

\section{Acknowledgments}

I thank A. Romain and J. Glasier for improving a draft of the manuscript, as well as R. Kaur, O. Nordmann and A. Radchenko for their valuable comments.

\section{Literature Cited}

Agosti, D., J. Moog, and U. Maschwitz. 1999. Revision of the Oriental plant-ant genus Cladomyrma. American Museum Novitates 3283: 1-24.

Alpert, G. D. 2007. A review of the ant genus Metapone Forel from Madagascar. Memoirs of the American Entomological Institute 80: 8-18.

Archibald, S. B., K. R. Johnson, R. W. Mathewes, and D. R. Greenwood. 2011. Intercontinental dispersal of giant thermophilic ants across the Arctic during early Eocene hyperthermals. Proceedings of the Royal Society (Series B, Biological Sciences) 278: 3679-3686.

Ashmead, W. H. 1905. A skeleton of a new arrangement of the families, subfamilies, tribes and genera of the ants, or the superfamily Formicoidea. Canadian Entomologist 37: 381-384.

Ax, P. 1985. Stem species and the stem lineage concept. Cladistics 1: 279-287.

Baroni Urbani, C., B. Bolton, and P. S. Ward. 1992. The internal phylogeny of ants (Hymenoptera: Formicidae). Systematic Entomology 17: 301-329.

Baroni Urbani, C., and M. L. de Andrade. 2003. The ant genus Proceratium in the extant and fossil record (Hymenoptera: Formicidae). Regionale di Scienze Naturali Monografie (Turin) 36: 1-492.

Baroni Urbani, C., and M. L. de Andrade. 2006. A new Protanilla Taylor, 1990 (Hymenoptera: Formicidae: Leptanillinae) from Sri Lanka. Myrmecologische Nachrichten 8: 45-47.

Barden, P., and D. A. Grimaldi. 2012. Rediscovery of the bizarre Cretaceous ant Haidomyrmex Dlussky (Hymenoptera: Formicidae), with two new species. American Museum Novitates 3755: 1-16.

Barden, P., and D. Grimaldi. 2013. A new genus of highly specialized ants in Cretaceous Burmese amber (Hymenoptera: Formicidae). Zootaxa 3681: 405-412.

Barden, P., and D. Grimaldi. 2014. A Diverse ant fauna from the Mid-Cretaceous of Myanmar (Hymenoptera: Formicidae). PloS One 9: e93627.

Barden, P., and D. Grimaldi. 2016. Adaptive radiation in socially advanced stem-group ants from the Cretaceous. Current Biology 26: 515-521.

Baum, D. A., and S. D. Smith. 2012. Tree thinking: an introduction to phylogenetic biology. Roberts and Company; Greenwood Village, CO. 476 p.

Bharti, H. 2003. Queen of the army ant Aenictus pachycerus (Hymenopetra, Formicidae, Aenictinae). Sociobiology 42: 715-718.

Bolton, B. 1973. A remarkable new arboreal ant genus (Hym. Formicidae) from West Africa. Entomologist's Monthly Magazine 108: 234-237. 
Bolton, B. 1994. Identification guide to the ant genera of the world. Harvard University Press; Cambridge. $222 \mathrm{p}$.

Bolton, B. 2003. Synopsis and classification of Formicidae. Memoirs of the American Entomological Institute 71: 1-370.

Bolton, B. 2007. Taxonomy of the dolichoderine ant genus Technomyrmex Mayr (Hymenoptera: Formicidae) based on the worker caste. Contributions of the American Entomological Institute 35: 1-150.

Bolton, B., and B. L. Fisher. 2008. Afrotropical ants of the ponerine genera Centromyrmex Mayr, Promyopias Santschi gen. rev. and Feroponera gen. n., with a revised key to genera of African Ponerinae (Hymenoptera: Formicidae). Zootaxa 1929: 1-37.

Bolton, B., and B. L. Fisher. 2011. Taxonomy of Afrotropical and West Palaearctic ants of the ponerine genus Hypoponera Santschi (Hymenoptera: Formicidae). Zootaxa 2843: 1-118.

Borowiec, M. L., and J. T. Longino. 2011. Three new species and reassessment of the rare Neotropical ant genus Leptanilloides (Hymenoptera, Formicidae, Leptanilloidinae). ZooKeys 133: 19-48.

Boudinot, B. E. 2015. Contributions to the knowledge of Formicidae (Hymenoptera, Aculeata): a new diagnosis of the family, the first global male-based key to subfamilies, and a treatment of early branching lineages. European Journal of Taxonomy 120: 1-62.

Brady, S. G., B. L. Fisher, T. R. Schultz, and P. S. Ward. 2014. The rise of army ants and their relatives: diversification of specialized predatory doryline ants. BMC Evolutionary Biology 14: 93.

Brady, S. G., T. R. Schultz, B. L. Fisher, and P. S. Ward. 2006. Evaluating alternative hypotheses for the early evolution and diversification of ants. Proceedings of the National Academy of Sciences 103: $18172-18177$.

Brady, S. G., and P. S. Ward. 2005. Morphological phylogeny of army ants and other dorylomorphs (Hymenoptera: Formicidae). Systematic Entomology 30: 593-618.

Brandão, C. R. F., J. L. M. Diniz, D. Agosti, and J. H. Delabie. 1999. Revision of the Neotropical ant subfamily Leptanilloidinae. Systematic Entomology 24: 17-36.

Brothers, D. J. 1999. Phylogeny and evolution of wasps, ants and bees (Hymenoptera, Chrysidoidea, Vespoidea and Apoidea). Zoologica Scripta 28: 233-250.

Cantino, P. D., and K. de Queiroz. 2010. International code of phylogenetic nomenclature. (Available at http://www. ohiou.edu/phylocode/. Last accessed March 2017.)

Clark, J. 1951. The Formicidae of Australia. Vol. 1. Subfamily Myrmeciinae. CSIRO; Melbourne, Australia. $230 \mathrm{p}$.

Creighton, W. S. 1950. The ants of North America. Bulletin of the Museum of Comparative Zoology 104: $1-585$.

Dlussky, G. M. 1975. Superfamily Formicoidea Latreille, 1802. Family Formicidae Latreille, 1802. p. 114-122. In: A. P. Rasnitsyn (ed.). Hymenoptera Apocrita of Mesozoic. Transactions of the Paleontological Institute, Academy of Sciences of the Union of Soviet Socialist Republics 147: 114-122. [In Russian].

Dlussky, G. M. 1983. A new family of Upper Cretaceous Hymenoptera: an "intermediate link" between the ants and the scolioids. Paleontologicheskii Zhurnal 3: 65-78. [In Russian].

Dlussky, G. M. 1987. New Formicoidea (Hymenoptera) of the Upper Cretaceous. Paleontologicheskii Zhurnal 1: 131-135. [In Russian.]

Dlussky, G. M. 1988. Ants of Sakhalin amber (Paleocene?). Paleontologicheskii Zhurnal 1: 50-61. [In Russian.]

Dlussky, G. M. 1996. Ants (Hymenoptera: Formicidae) from Burmese amber. Paleontological Journal 30: 449-454.

Dlussky, G. M. 1999a. New ants (Hymenoptera, Formicidae) from Canadian amber. Paleontologicheskii Zhurnal 4: 73-76. [In Russian.]

Dlussky, G. M. 1999b. The first find of the Formicoidea (Hymenoptera) in the lower Cretaceous of the northern hemisphere. Paleontologicheskii Zhurnal 3: 62-66. [In Russian.]

Dlussky, G. M., D. J. Brothers, and A. P. Rasnitsyn. 2004. The first Late Cretaceous ants (Hymenoptera: Formicidae) from southern Africa, with comments on the origin of the Myrmicinae. Insect Systematics and Evolution 35: 1-13. 
Dlussky, G. M., and E. B. Fedoseeva. 1988. Origin and early stages of evolution in ants. p. 70-144. In: A. G. Ponomarenko (ed.). Cretaceous biocenotic crisis and insect evolution. Nauka; Moscow. 230 p. [In Russian.]

Donoso, D. A. 2012. Additions to the taxonomy of the armadillo ants (Hymenoptera, Formicidae, Tatuidris). Zootaxa 3503: 61-81.

Dubois, A. 2007. Phylogeny, taxonomy and nomenclature: the problem of taxonomic categories and of nomenclatural ranks. Zootaxa 1519: 27-68.

Emery, C. 1901. Note sulle Doriline. Bollettino della Societa Entomologica Italiana 33: 43-56.

Engel, M. S., and D. A. Grimaldi. 2005. Primitive new ants in Cretaceous amber from Myanmar, New Jersey, and Canada (Hymenoptera: Formicidae). American Museum Novitates 3485: 1-23.

Ereshefsky, M. 2001. The poverty of the Linnaean hierarchy: a philosophical study of biological taxonomy. Cambridge University Press; Cambridge, U.K. 316 p.

Faul, F., E. Erdfelder, A.-G. Lang, and A. Buchner. 2007. G*Power 3: A flexible statistical power analysis program for the social, behavioral, and biomedical sciences. Behavior Research Methods 39: 175-191.

Fisher, B. L. 2002. AntWeb. (Available at http://www.antweb.org. Last accessed March 2017.)

Folgarait, P. J. 1998. Ant biodiversity and its relationship to ecosystem functioning: a review. Biodiversity and Conservation 7.9: 1221-1244.

Forel, A. 1893. Sur la classification de la famille des Formicides, avec remarques synonymiques. Annales de la Société Entomologique de Belgique 37: 161-167.

Greggers, U., G. Koch, V. Schmidt, A. Dürr, A. Floriou-Servou, D. Piepenbrock, M. C. Göpfert, and R. Menzel. 2013. Reception and learning of electric fields in bees. Proceedings of the Royal Society B 280: doi:10.1098/rspb.2013.0528.

Grimaldi, D., and D. Agosti. 2000. A formicine in New Jersey Cretaceous amber (Hymenoptera: Formicidae) and early evolution of the ants. Proceedings of the National Academy of Sciences of the United States of America 97: 13678-13683.

Grimaldi, D., D. Agosti, and J. M. Carpenter. 1997. New and rediscovered primitive ants (Hymenoptera: Formicidae) in Cretaceous amber from New Jersey, and their phylogenetic relationships. American Museum Novitates 3208: 1-43.

Hasiotis, S. T., and T. M. Demko. 1996. Terrestrial and freshwater trace fossils, upper Jurassic Morrison formation, Colorado Plateau. The Continental Jurassic, Museum of Northern Arizona Bulletin 60: 355-370.

Hennig, W. 1966. Phylogenetic systematics. University of Illinois Press; Urbana, IL. 263 p.

Heraty, J., F. Ronquist, J. M. Carpenter, D. Hawks, S. Schulmeister, A. P. Dowling, D. Murray, J. Munro, W. C. Wheeler, N. Schiff, and M. Sharkey. 2011. Evolution of the hymenopteran megaradiation. Molecular Phylogenetics and Evolution 60: 73-88.

Hölldobler, B., and E. O. Wilson. 1990. The ants. Belknap Press; Cambridge, MA. 732 p.

Jablonski, D., and W. G. Chaloner. 1994. Extinctions in the fossil record (and discussion). Philosophical Transactions of the Royal Society of London, Series B 344: 11-17.

Johnson, B. R., M. L. Borowiec, J. C. Chiu, E. K. Lee, J. Atallah, and P. S. Ward. 2013. Phylogenomics resolves evolutionary relationships among ants, bees, and wasps. Current Biology 23: 2058-2062.

Joyce, W. G., Parham J. F., and J. A. Gauthier. 2004. Developing a protocol for the conversion of rank-based taxon names to phylogenetically defined clade names, as exemplified by turtles. Journal of Paleontology 78: 989-1013.

Kamikouchi, A., H. K. Inagaki, T. Effertz, O. Hendrich, A. Fiala, M. C. Göpfert, and K. Ito. 2009. The neural basis of Drosophila gravity-sensing and hearing. Nature 458: 165-171.

Ketterl, J., and M. Verhaagh. 2004. Acanthoponera mucronata (Roger, 1860) (Hymenoptera: Formicidae), first record in Peru and Rio Grande do Sul, Brazil, with description of its male. Revista Peruana de Entomologia 44: 65-68.

LaPolla, J. S. 2009. Taxonomic revision of the Southeast Asian ant genus Euprenolepis. Zootaxa 2046: $1-25$.

LaPolla, J. S., G. M. Dlussky, and V. Perrichot. 2013. Ants and the Fossil Record. Annual review of Entomology 58: 609-630. 
Longino, J. T. 2003. A new Costa Rican species of Leptanilloides (Hymenoptera: Formicidae: doryline section: Leptanilloidinae). Zootaxa 264: 1-6.

Lucky, A., M. D. Trautwein, B. S. Guenard, M. D. Weiser, and R. R. Dunn. 2013. Tracing the rise of ants-out of the ground. PloS One 8: e84012.

Lucky, A., and P. S. Ward. 2010. Taxonomic revision of the ant genus Leptomyrmex Mayr (Hymenoptera: Formicidae). Zootaxa 2688: 1-67.

MacKay, W. P. 1993. A review of the new world ant of the genus Dolichoderus. Sociobiology 22: 1-148.

McDonald, J. H. 2014. Handbook of Biological Statistics (3rd ed.). Sparky House Publishing; Baltimore, MD. 299 p.

McKellar, R. C., J. R. N. Glasier, and M. S. Engel. 2013a. New ants (Hymenoptera: Formicidae: Dolichoderinae) from Canadian Late Cretaceous amber. Bulletin of Geosciences 88: 583-594.

McKellar, R. C., J. R. N. Glasier, and M. S. Engel. 2013b. A new trap-jawed ant (Hymenoptera: Formicidae: Haidomyrmecini) from Canadian Late Cretaceous amber. The Canadian Entomologist 145: 454-465.

McKellar, R. C. and A. P. Wolfe. 2010. Canadian amber. p. 96-113. In: D. Penney (ed.). Biodiversity of fossils in amber from the major world deposits. Siri Scientific Press; Manchester. 304 p.

Moreau, C. S., C. D. Bell, R. Vila, S. B. Archibald, and N. E. Pierce. 2006. Phylogeny of the ants: diversification in the age of Angiosperms. Science 312: 101-104.

Nel, A., G. Perrault, V. Perrichot, and D. Néraudeau. 2004. The oldest ant in the Lower Cretaceous amber of Charente-Maritime (SW France) (Insecta: Hymenoptera: Formicidae). Geologica Acta 2: 23-29.

Odling-Smee, F. J., K. N. Laland, and M. W. Feldman. 2003. Niche construction: the neglected process in evolution. Princeton University Press; Princeton, NJ. 472 p.

Ogata, K., M. Terayama, and K. Masuko. 1995. The ant genus Leptanilla: discovery of the workerassociated male of $L$. japonica, and a description of a new species from Taiwan (Hymenoptera: Formicidae: Leptanillinae). Systematic Entomology 20: 27-34.

Perrichot, V. 2014. A new species of the Cretaceous ant Zigrasimecia based on the worker caste reveals placement of the genus in the Sphecomyrminae (Hymenoptera: Formicidae). Myrmecological News 19: 165-169.

Perrichot, V. 2015. A new species of Baikuris (Hymenoptera: Formicidae: Sphecomyrminae) in midCretaceous amber from France. Cretaceous Research 52: 585-590.

Perrichot, V., A. Nel, D. Neraudeau, S. Lacau, and T. Guyot. 2008. New fossil ants in French Cretaceous amber (Hymenoptera: Formicidae). Naturwissenschaften 95: 91-97.

Perrichot, V., B. Wang, and M. S. Engel. 2016. Extreme morphogenesis and ecological specialization among Cretaceous basal ants. Current Biology 26: 1468-1472.

Peters, R. S., B. Meyer, L. Krogmann, J. Borner, K. Meusemann, K. Schütte, O. Niehuis, and B. Misof. 2011. The taming of an impossible child: a standardized all-in approach to the phylogeny of Hymenoptera using public database sequences. BMC Biology 9: 55.

Pigliucci, M., C. J. Murren, and C. D. Schlichting. 2006. Phenotypic plasticity and evolution by genetic assimilation. Journal of Experimental Biology 209: 2362-2367.

Pilgrim, E. M., C. D. Von Dohlen, and J. P. Pitts. 2008. Molecular phylogenetics of Vespoidea indicate paraphyly of the superfamily and novel relationships of its component families and subfamilies. Zoologica Scripta 37: 539-560.

Pleijel, F., and G. W. Rouse. 2003. Ceci n'est pas une pipe: names, clades and phylogenetic nomenclature. Journal of Zoological Systematics and Evolutionary Research 41: 162-174.

Price, T. D., A. Qvarnström, and D. E. Irwin. 2003. The role of phenotypic plasticity in driving genetic evolution. Proceedings of the Royal Society of London (Series B: Biological Sciences) 270: 1433-1440.

Rabeling, C., J. M. Brown, and M. Verhaagh. 2008. Newly discovered sister lineage sheds light on early ant evolution. Proceedings of the National Academy of Sciences 105: 14913-14917.

Radchenko, A. G. 1991. Ants of the genus Strongylognathus (Hymenoptera, Formicidae) of the fauna of the USSR. Zoologicheskii Zhurnal 70: 84-90. [in Russian]

Radchenko, A. G. 1994. Identification table for ants of the genus Myrmica (Hymenoptera, Formicidae) from central and eastern Palearctic. Zoologicheskii Zhurnal 73: 130-145. [In Russian] 
Radchenko, A. G., and G. W. Elmes. 1998. Taxonomic revision of the ritae species-group of the genus Myrmica (Hymenoptera, Formicidae). Vestnik Zoologii 32: 3-27.

Radchenko, A., and G. W. Elmes. 2003. A taxonomic revision of the socially parasitic Myrmica ants (Hymenoptera: Formicidae) of the Palaearctic region. Annales Zoologici 53: 217-243.

Radchenko, A., G. W. Elmes, and M. Woyciechowski. 2002. An appraisal of Myrmica bergi Ruzsky, 1902 and related species (Hymenoptera: Formicidae). Annales Zoologici (Warsawa) 52: 409-421.

Radchenko, A. G., and E. E. Perkovsky. 2016. The ant Aphaenogaster dlusskyana sp. nov. (Hymenoptera, Formicidae) from the Sakhalin amber - the earliest described species of an extant genus of Myrmicinae. Paleontological Journal 50: 936-946.

Santschi, F. 1915. Nouvelles fourmis d'Afrique. Annales de la Société Entomologique de France 84: $244-282$.

Schmidt, C. 2013. Molecular phylogenetics of ponerine ants (Hymenoptera: Formicidae: Ponerinae). Zootaxa 3647: 201-250.

Schmidt, F. A., R. M. Feitosa, F. de Moraes Rezende, and R. Silva de Jesus. 2013. News on the enigmatic ant genus Anillidris (Hymenoptera: Formicidae: Dolichoderinae: Leptomyrmecini). Myrmecological News 19: 25-30.

Seifert, B. 1988. A taxonomic revision of the Myrmica species of Europe, Asia Minor, and Caucasus (Hymenoptera, Formicidae). Abhandlungen und Berichte des Naturkundemuseums Görlitz 62: 1-75.

Seifert, B. 1992. A taxonomic revision of the Palaearctic members of the ant subgenus Lasius s. str. (Hymenoptera, Formicidae). Abhandlungen und Berichte des naturkundemuseums Görlitz 66: 1-67.

Seifert, B. 2000. A taxonomic revision of the ant subgenus Coptoformica Mueller, 1923 (Hymenoptera, Formicidae). Zoosystema-Paris 22: 517-568.

Seifert, B. 2003. The ant genus Cardiocondyla (Insecta: Hymenoptera: Formicidae) - a taxonomic revision of the C. elegans, C. bulgarica, C. batesii, C. nuda, C. shuckardi, C. stambuloffii, C. wroughtonii, C. emeryi and C. minutior species groups. Annalen des Naturhistorischen Museums in Wien (B, Botanik, Zoologie) 104: 203-338.

Shattuck, S. O. 1992. Generic revision of the ant subfamily Dolichoderinae (Hymenoptera: Formicidae). Sociobiology 21: 1-181.

Shattuck, S. O. 2008. Australian ants of the genus Aphaenogaster (Hymenoptera: Formicidae). Zootaxa 1677: 25-45.

Shattuck, S. O., and N. J. Barnett. 2006. Australian species of the ant genus Diacamma (Hymenoptera: Formicidae). Myrmecologische Nachrichten 8: 13-19.

Simpson, S. J., G. A. Sword, and N. Lo. 2011. Polyphenism in insects. Current Biology 21: R738-R749.

Smith, M. R. 1952. The correct name for the group of ants formerly known as Pseudomyrma (Hymenoptera). Proceedings of the Entomological Society of Washington 54: 97-98.

Stephens, J. F. 1829. A systematic catalogue of British insects: being an attempt to arrange all the hitherto discovered indigenous insects in accordance with their natural affinities. Baldwin and Cradock; London. 388 p.

Taylor, R. W. 1978. Nothomyrmecia macrops: a living-fossil ant rediscovered. Science 201: 979-985.

Taylor, R. W. 1980. Notes on the Russian endemic ant genus Aulacopone Arnoldi (Hymenoptera: Formicidae). Psyche (Cambridge) 86: 53-361.

Ward, P. S. 1990. The ant subfamily Pseudomyrmecinae (Hymenoptera: Formicidae): generic revision and relationship to other formicids. Systematic Entomology 15: 449-489.

Ward, P. S. 1999. Systematics, biogeography and host plant associations of the Pseudomyrmex viduus group (Hymenoptera: Formicidae), Triplaris-and Tachigali-inhabiting ants. Zoological Journal of the Linnean Society 126: 451-540.

Ward, P. S. 2007. Phylogeny, classification, and species-level taxonomy of ants (Hymenoptera: Formicidae). Zootaxa 1668: 549-563.

Ward, P. S. 2011. Integrating molecular phylogenetic results into ant taxonomy (Hymenoptera: Formicidae). Myrmecological News 15: 21-29.

Ward, P. S., B. B. Blaimer, and B. L. Fisher. 2016. A revised phylogenetic classification of the ant subfamily Formicinae (Hymenoptera: Formicidae), with resurrection of the genera Colobopsis and Dinomyrmex. Zootaxa 4072: 343-357. 
Ward, P. S., S. G. Brady, B. L. Fisher, and T. R. Schultz. 2010. Phylogeny and biogeography of dolichoderine ants: effects of data partitioning and relict taxa on historical inference. Systematic Biology 59: 342-362.

Ward, P. S., S. G. Brady, B. L. Fisher, and T. R. Schultz. 2015. The evolution of myrmicine ants: phylogeny and biogeography of a hyperdiverse ant clade (Hymenoptera: Formicidae). Systematic Entomology 40: 61-81.

Ward, P. S., and B. L. Fisher. 2016. Tales of dracula ants: the evolutionary history of the ant subfamily Amblyoponinae (Hymenoptera: Formicidae). Systematic Entomology 41: 683-693.

West-Eberhard, M. J. 2003. Developmental plasticity and evolution. Oxford University Press; New York, NY. 794 p.

Wheeler, W. M. 1923. Social life among the insects. Harcourt, Brace and Co.; New York, NY. 375 p.

Wheeler, W. M. 1925. The finding of the queen of the army ant Eciton hamatum Fabricius. Biological Bulletin (Woods Hole) 49: 139-149.

Wheeler, W. M. 1926. Les sociétés d'insectes: leur origine, leur évolution. Gaston Doin and Co.; Paris, France. 468 p.

Wild, A. L. 2004. Taxonomy and distribution of the Argentine ant, Linepithema humile (Hymenoptera: Formicidae). Annals of the Entomological Society of America 97: 1204-1215.

Wilson, E. O. 1985. Ants from the Cretaceous and Eocene amber of North America. Psyche 92: 205-216.

Wilson, E. O. 1987. The earliest known ants: an analysis of the Cretaceous species and an inference concerning their social organization. Paleobiology 13: 44-53.

Wilson, E. O., T. Eisner, G. C. Wheeler, and J. Wheeler. 1956. Aneuretus simoni Emery, a major link in ant evolution. Bulletin of the Museum of Comparative Zoology at Harvard College 115: 81-99.

Wilson, E. O., F. M. Carpenter, and W. L. Brown. 1967. The first Mesozoic ants, with the description of a new subfamily. Psyche 74: 1-19.

Wilson, E.O., and B. Hölldobler. 2005. The rise of the ants: a phylogenetic and ecological explanation. Proceedings of the National Academy of Sciences 102: 7411-7414.

Yanega, D. 1997. Demography and sociality in halictine bees (Hymenoptera: Halictidae). p. 293-315. In: J. Choe, and B. Crespi (eds.). The evolution of social behavior in insects and arachnids. Cambridge University Press; Cambridge, U.K. 552 p.

Yek, S. H., and U. G. Mueller. 2011. The metapleural gland of ants. Biological Reviews 86: 774-791.

Received April 7, 2017; Accepted June 16, 2017.

Review Editor Kevin Williams. 
Table 1. Leg segment measurements (in $\mathrm{mm}$ ) of Boltonimecia canadensis.

\begin{tabular}{llll}
\hline Segment & Front leg & Middle leg & Hind leg \\
\hline coxa & 0.40 & 0.34 & 0.50 \\
femur & 0.75 & 0.85 & 1.25 \\
tibia & 0.75 & 0.75 & 1.20 \\
tarsal segment 1 & 0.50 & 0.60 & 0.90 \\
tarsal segment 2 & 0.15 & 0.25 & 0.25 \\
tarsal segment 3 & 0.20 & 0.20 & 0.25 \\
tarsal segment 4 & 0.10 & 0.15 & 0.17 \\
tarsal segment 5 & 0.15 & 0.15 & 0.25 \\
pretarsal claws & 0.15 & 0.15 & 0.15 \\
total length & 3.30 & 3.60 & 5.07 \\
\hline
\end{tabular}



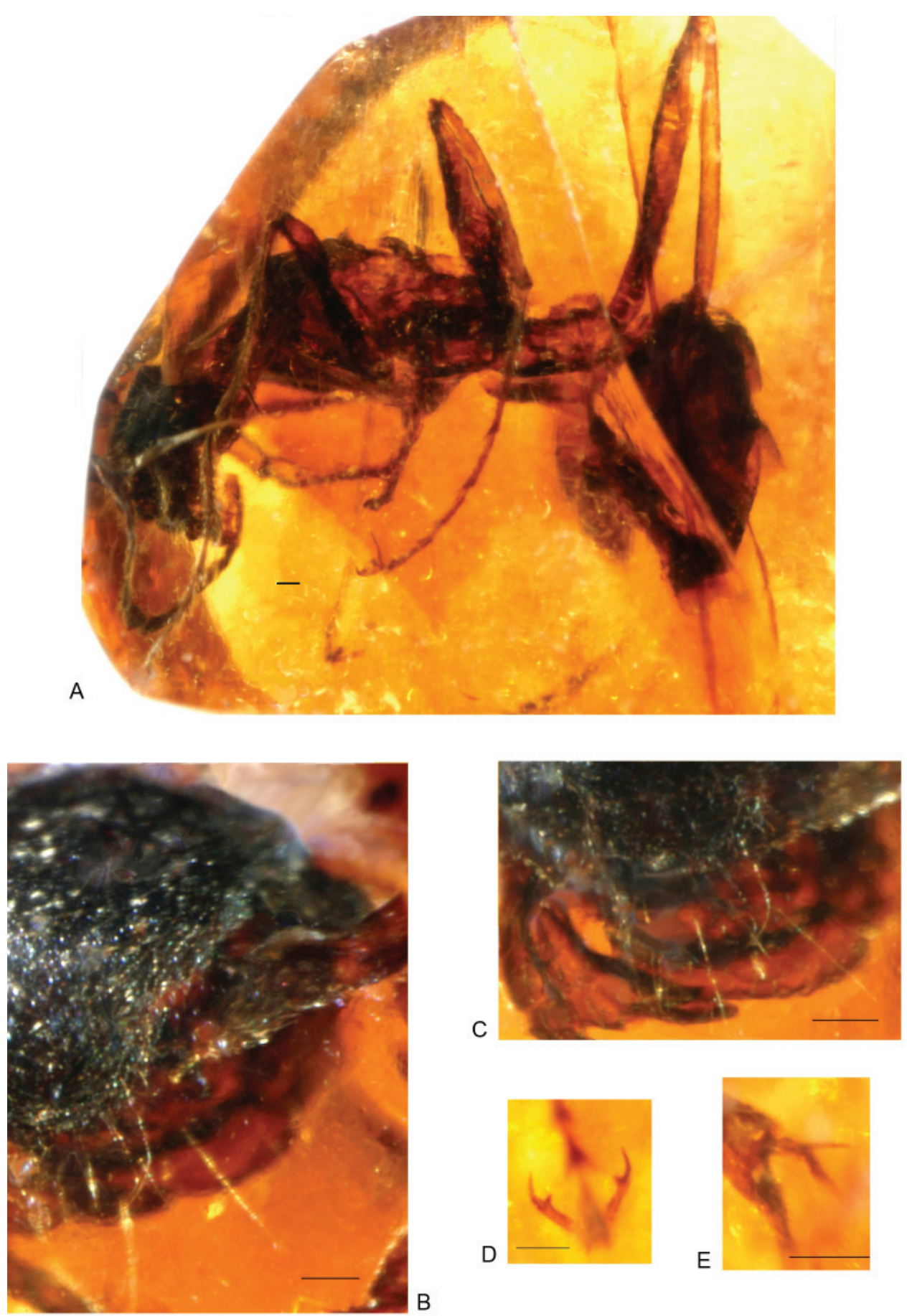

Figure 1. Photographs of Boltonimecia canadensis. A) General habitus, lateral view. B) Part of head, anterodorsal view. C) Clypeus and mandibles. D) Pretarsal claws. E) Metatibial spurs. Scale line $=0.1 \mathrm{~mm}$. 

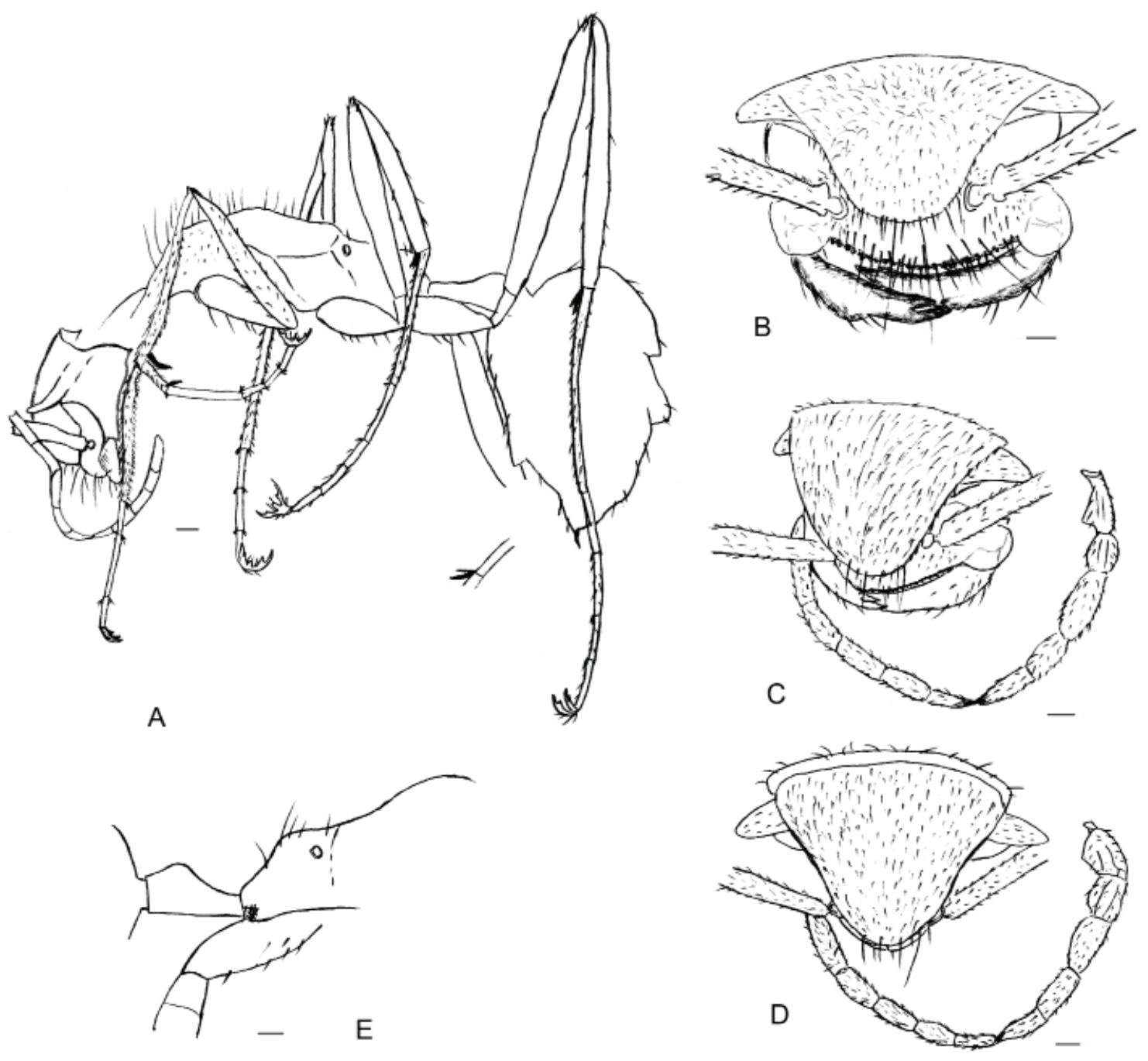

Figure 2. Drawings of Boltonimecia canadensis. A) General habitus, lateral view (pubescence on mesosoma, legs, and gaster omitted). B) Head, anterodorsal view (reconstruction). C) Head, anterolateral view. D) Head, dorsal view (reconstruction). E) Propodeum, lateral view. Scale line $=0.1 \mathrm{~mm}$. 

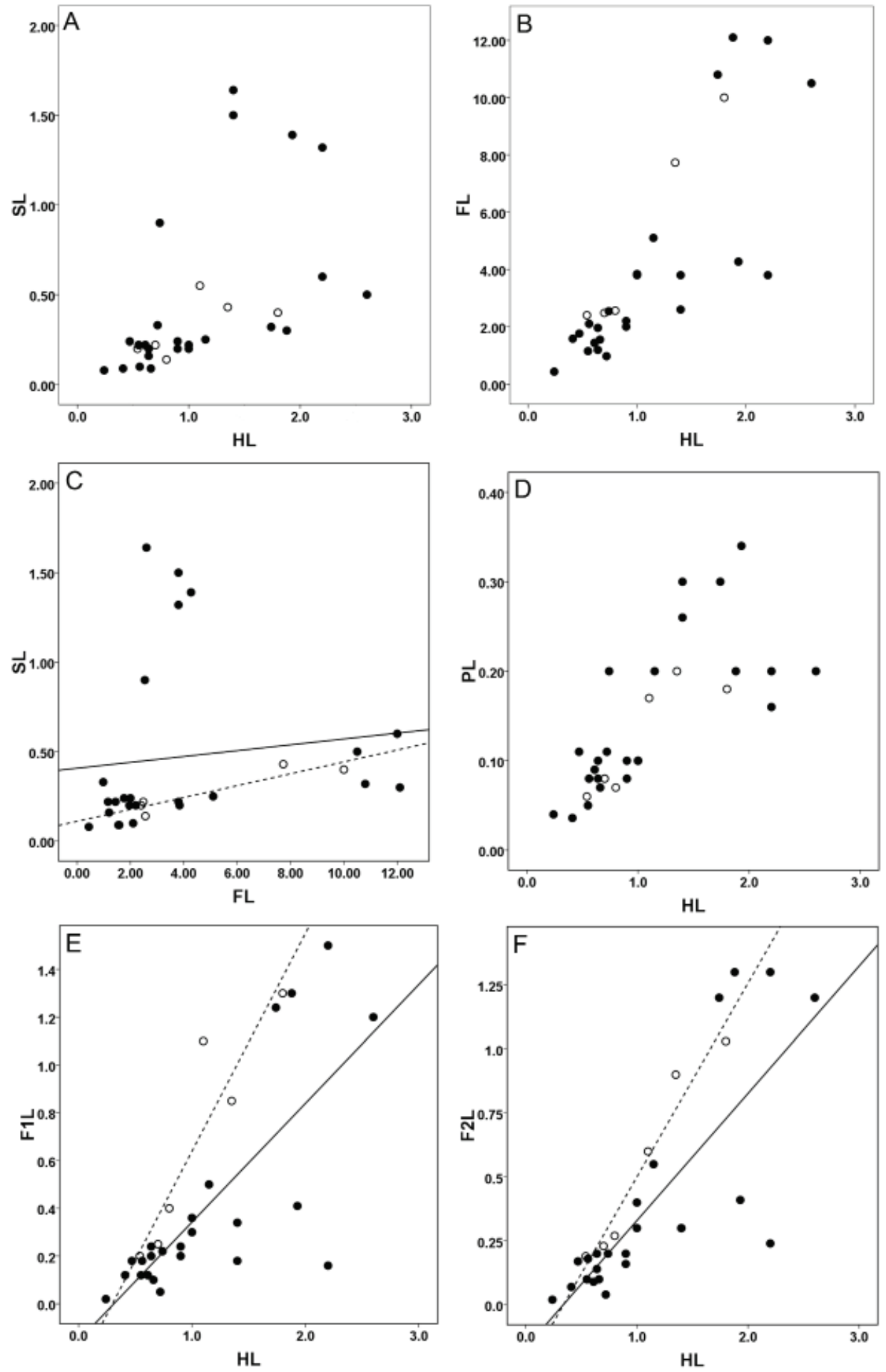

Figure 3. Bivariate plots (males). A) Scape length versus head length. B) Flagellum length versus head length. C) Scape length versus flagellum length. D) Pedicel length versus head length. E) Flagellomere 1 length versus head length. F) Flagellomere 2 length versus head length. (Note: Filled circles are crown-group ants; open circles are stem-group ants; regression lines for both groups (crown-group ants - solid line, stem-group ants - dashed line) are shown in cases where statistical difference between them was found). 

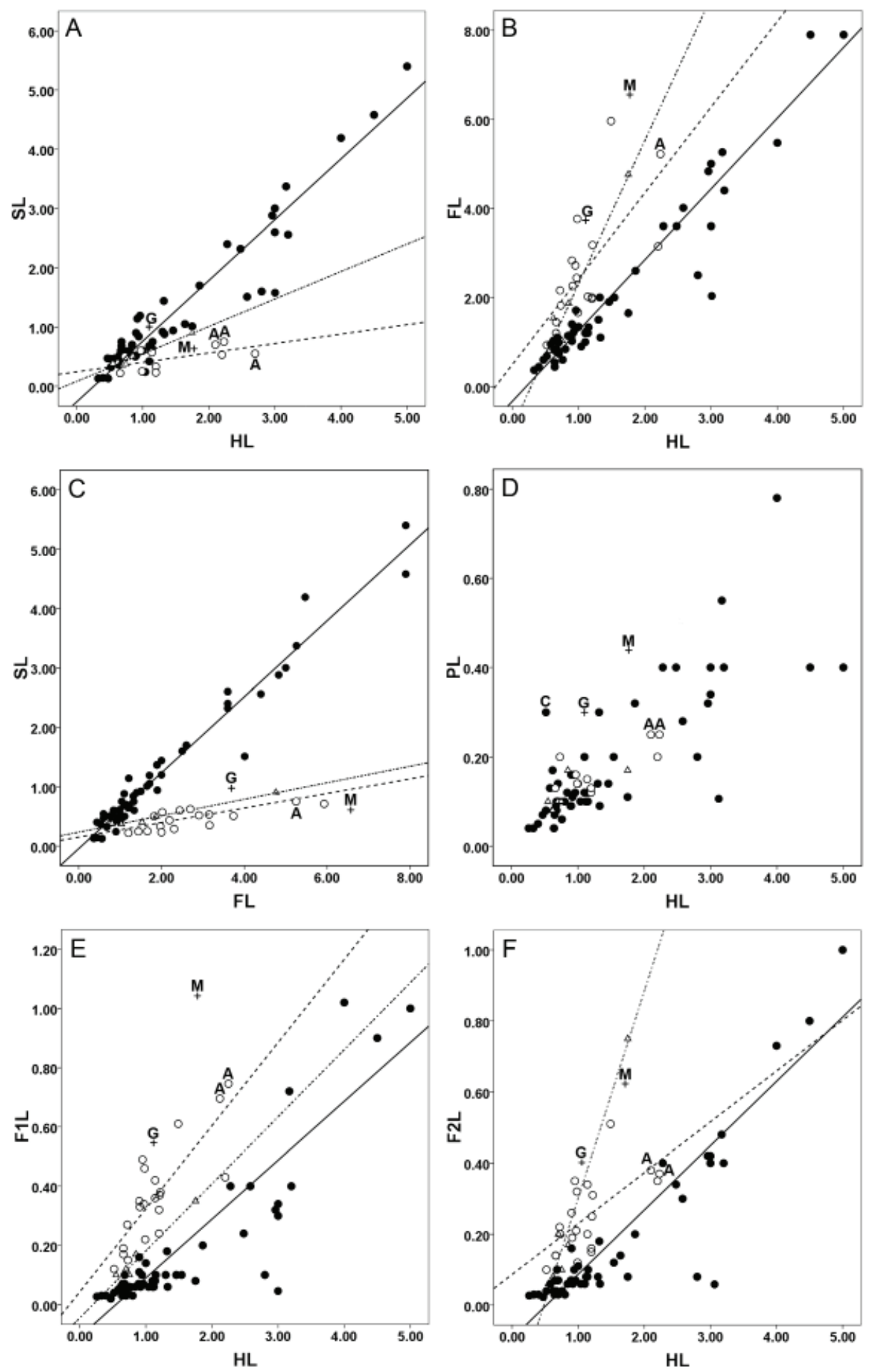

Figure 4. Bivariate plots (females). A) Scape length versus head length. B) Flagellum length versus head length. C) Scape length versus flagellum length. D) Pedicel length versus head length. E) Flagellomere 1 length versus head length. F) Flagellomere 2 length versus head length. (Note: Filled circles are crown-group ants; open circles are Sphecomyrmini; triangles are Haidomyrmecini; A - Armaniinae (sensu Bolton 2003); C - Cananeuretus occidentalis; G - Gerontoformica cretacica; M - Myanmyrma gracilis. Regression lines for crown-group ants (solid line), Sphecomyrmini (dashed line), and Haidomyrmecini (dash-dotted line) are shown in cases where statistical difference between at least two groups was found). 

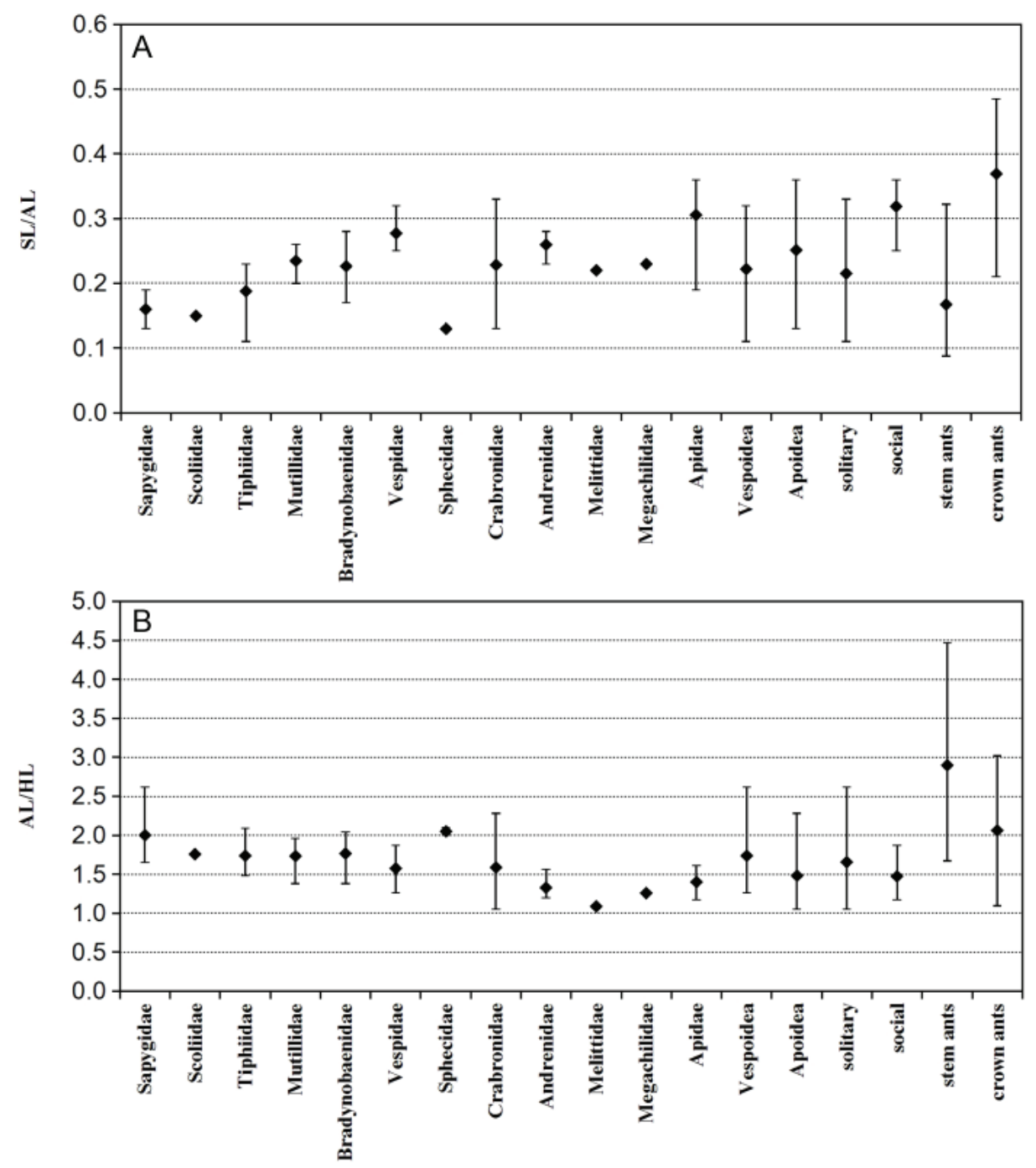

Figure 5. Range for the indices SL/AL and AL/HL in females of Vespoidea and Apoidea. A) Range for SL/AL. B) Range for AL/HL. (Note: Diamonds are arithmetic means. Data on Vespoidea and Apoidea are from Dlussky and Fedoseeva (1988), sorted by families according to the current classification. Vespoidea: families Sapygidae, Scoliidae, Tiphiidae, Mutillidae, Bradynobaenidae, Vespidae. Apoidea: families Sphecidae, Crabronidae, Andrenidae, Melittidae, Megachilidae, Apidae. Social Hymenoptera: Vespa sp., Vespula sp., Polistes sp., Apis sp. (1 species each), Bombus sp. (4 species). Stem ants: all stem-group ants from Table S1. Crown ants: all crown-group ants from Table S1). 

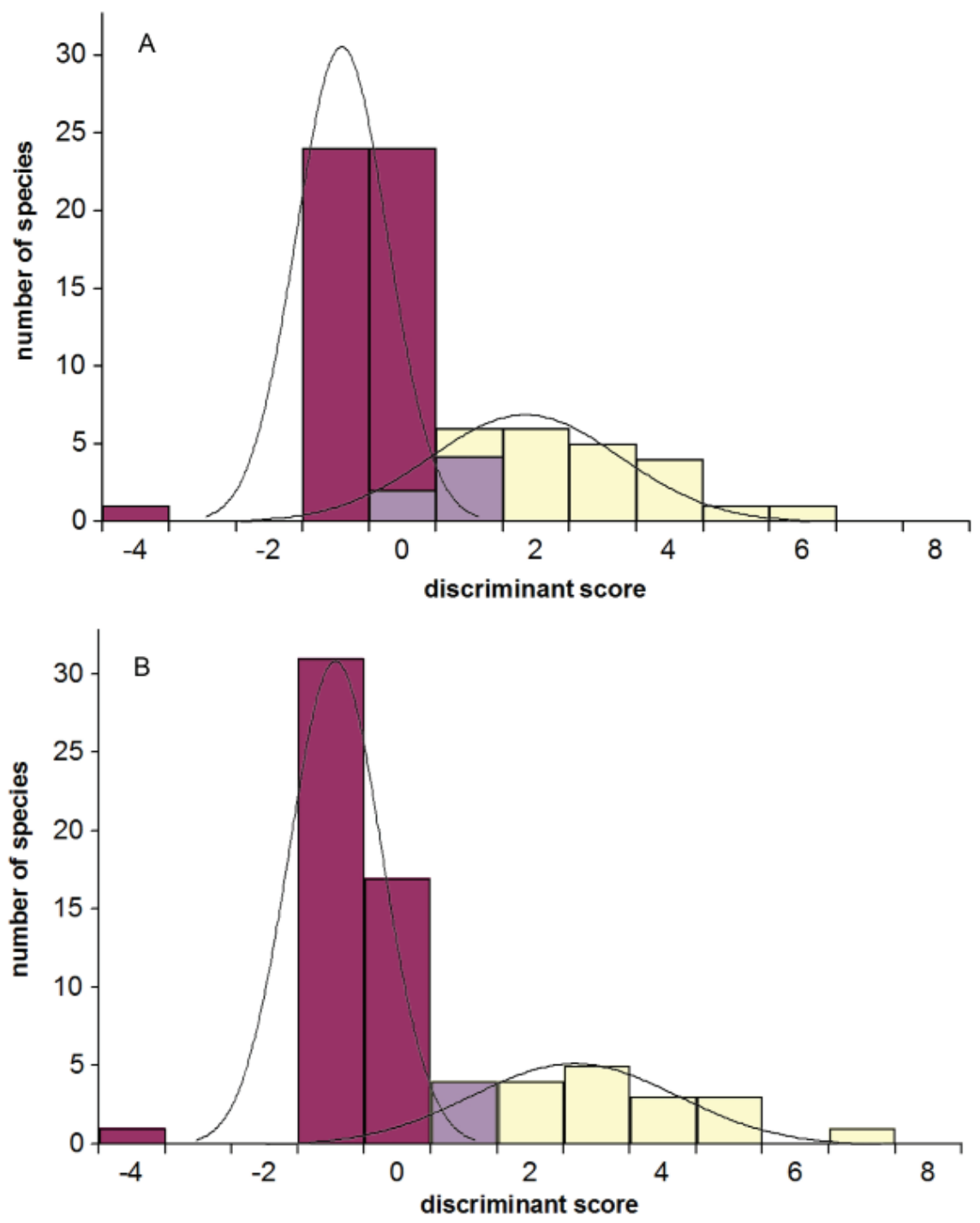

Figure 6. Results of canonical discriminant analysis. A) All species. B) Haidomyrmecini removed. (Note: Red violet bars are crown-group ants; yellow bars are stem-group ants; violet bars - area of overlap. Lines are Gaussian curves fitted to the data). 


\section{Appendix 1}

Table S1. List of species sampled.

$\dagger$ extinct; w - worker, g - gyne, m - male.

\begin{tabular}{|c|c|}
\hline Taxon & Reference \\
\hline $\begin{array}{l}\dagger \text { Stem clades } \\
\text { Sphecomyrminae } \\
\text { Sphecomyrma freyi Wilson and Brown, } 1967 \text { (w) }\end{array}$ & $\begin{array}{l}\text { Wilson et al. } 1967 \text { (referred to as } \\
\text { Sphecomyrma freyi \#1 in this study) } \\
\text { Grimaldi et al. } 1997 \text { (neotype) } \\
\text { (referred to as Sphecomyrma freyi \#2 } \\
\text { in this study) } \\
\text { Engel and Grimaldi } 2005 \text { (specimen } \\
\text { B) (referred to as Sphecomyrma freyi } \\
\# 3 \text { in this study) }\end{array}$ \\
\hline Sphecomyrma mesaki Engel and Grimaldi, 2005 (w) & Engel and Grimaldi 2005 \\
\hline Sphecomyrma sp. (m) & Grimaldi et al. 1997 \\
\hline Gerontoformica orientalis (Engel and Grimaldi, 2005) (w) & Engel and Grimaldi 2005 \\
\hline Gerontoformica occidentalis (Perrichot, et al., 2008) (w) & Perrichot et al. 2008 \\
\hline Gerontoformica contegus (Barden and Grimaldi, 2014) (w) & Barden and Grimaldi 2014 \\
\hline Gerontoformica gracilis (Barden and Grimaldi, 2014) (w) & Barden and Grimaldi 2014 \\
\hline Gerontoformica magnus (Barden and Grimaldi, 2014) (w) & Barden and Grimaldi 2014 \\
\hline Gerontoformica pilosus (Barden and Grimaldi, 2014) (w) & Barden and Grimaldi 2014 \\
\hline Gerontoformica rubustus (Barden and Grimaldi, 2014) (w) & Barden and Grimaldi 2014 \\
\hline Gerontoformica rugosus (Barden and Grimaldi, 2014) (w) & Barden and Grimaldi 2014 \\
\hline Gerontoformica spiralis (Barden and Grimaldi, 2014) (w) & Barden and Grimaldi 2014 \\
\hline Gerontoformica subcuspis (Barden and Grimaldi, 2014) (w) & Barden and Grimaldi 2014 \\
\hline Gerontoformica tendir (Barden and Grimaldi, 2014) (w) & Barden and Grimaldi 2014 \\
\hline Haidomyrmodes mammuthus Perrichot, et al., 2008 (w, g) & $\begin{array}{l}\text { Perrichot et al. } 2008 \text { (gyne referred to } \\
\text { as Haidomyrmodes mammuthus } \# 1 \\
\text { (g) in this study; worker referred to as } \\
\text { Haidomyrmodes mammuthus } \# 2 \text { in } \\
\text { this study) }\end{array}$ \\
\hline Haidomyrmex cerberus Dlussky, 1996 (w) & Dlussky 1996 \\
\hline Haidomyrmex scimitarus Barden and Grimaldi, 2012 (g) & Barden and Grimaldi 2012 \\
\hline Haidomyrmex zigrasi Barden and Grimaldi, 2012 (w) & Barden and Grimaldi 2012 \\
\hline Haidoterminus cippus McKellar, Glasier and Engel, 2013 (w) & McKellar et al. 2013b \\
\hline
\end{tabular}


Zigrasimecia tonsora Barden and Grimaldi, 2013 (g)

Zigrasimecia ferox Perrichot, 2014 (w)

Baikuris mandibularis Dlussky, 1987 (m)

Baikuris casei Grimaldi, Agosti and Carpenter, 1997 (m)

Baikuris maximus Perrichot, 2014 (m)

Dlusskyidris zherichini (Dlussky, 1975) (m)

Boltonimecia canadensis (Wilson, 1985) (w)

Armaniinae (sensu Bolton 2003)

Armania robusta Dlussky, 1983 (g)

Pseudarmania rasnitsyni Dlussky, 1983 (g)

Archaeopone taylori Dlussky, 1983 (m)

Orapia rayneri Dlussky, Brothers and Rasnitsyn, 2004 (g)

Incertae sedis

Myanmyrma gracilis Engel and Grimaldi, 2005 (w)

Gerontoformica cretacica Nel and Perrault, 2004 (w)

Crown clade

Martialinae

Martialis heureka Rabeling and Verhaagh, 2008 (w)

Leptanillinae

Leptanilla taiwanensis Ogata, Terayama and Masuko, 1995 (w, g)

Leptanilla sp. (m)

Proceratiinae

Discothyrea sp. (w, g, m)

Amblyoponinae

Stigmatomma pallipes (Haldeman, 1844) (w, g, m)

Ponerinae

Ponera pennsylvanica Buckley, 1866 (w, g, m)

Neoponera villosa (Fabricius, 1804) (w, g, m)

Paraponerinae

Paraponera clavata (Fabricius, 1775) (w, g, m)
Barden and Grimaldi 2013

Perrichot 2014 (paratype referred to as Zigrasimecia ferox \#1 in this study; holotype referred to as Zigrasimecia ferox $\# 2$ in this study)

Dlussky 1987

Grimaldi et al. 1997

Perrichot 2014

Dlussky 1975

$\mathrm{CNC}$

Dlussky 1983

Dlussky 1983

Dlussky 1983

Dlussky et al. 2004

Engel and Grimaldi 2005

Nel et al. 2004

Rabeling et al. 2008

Ogata et al. 1995

$\mathrm{CNC}$

$\mathrm{CNC}$

$\mathrm{CNC}$

$\mathrm{CNC}$

$\mathrm{CNC}$

$\mathrm{CNC}$ 


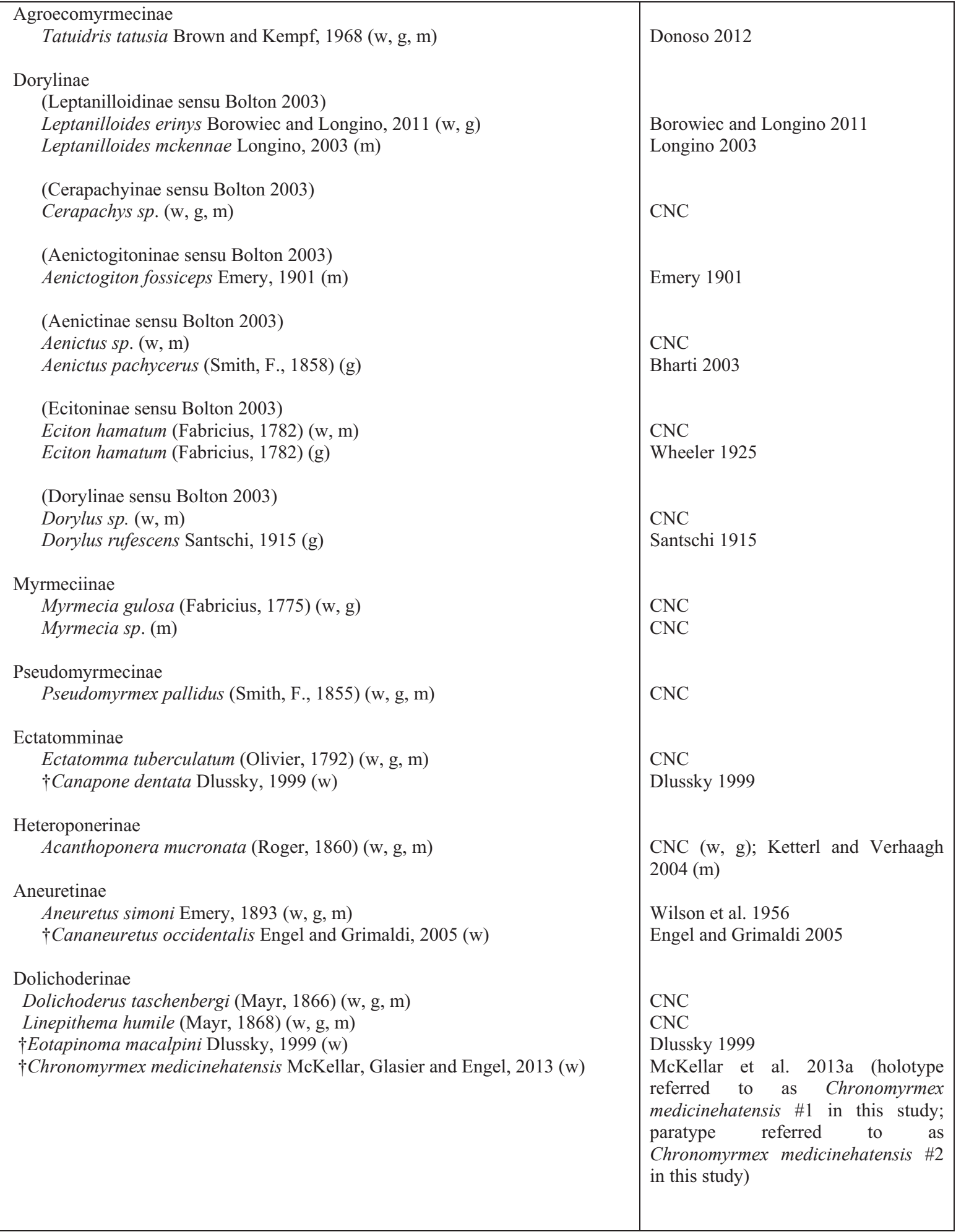


Formicinae

Camponotus pennsylvanicus (De Geer, 1773) (w, g, m)

Formica glacialis Wheeler, W.M., 1908 (w, g, m)

$\dagger$ Kyromyrma neffi Grimaldi and Agosti, 2000 (w)

Myrmicinae

Aphaenogaster honduriana Mann, 1922 (w, g, m)

Manica invidia Bolton, 1995 (w, g, m)

$\dagger$ Brownimeciinae

Brownimecia clavata Grimaldi, Agosti and Carpenter, 1997 (w)
$\mathrm{CNC}$

$\mathrm{CNC}$

Grimaldi and Agosti 2000

$\mathrm{CNC}$

$\mathrm{CNC}$

Grimaldi et al. 1997 


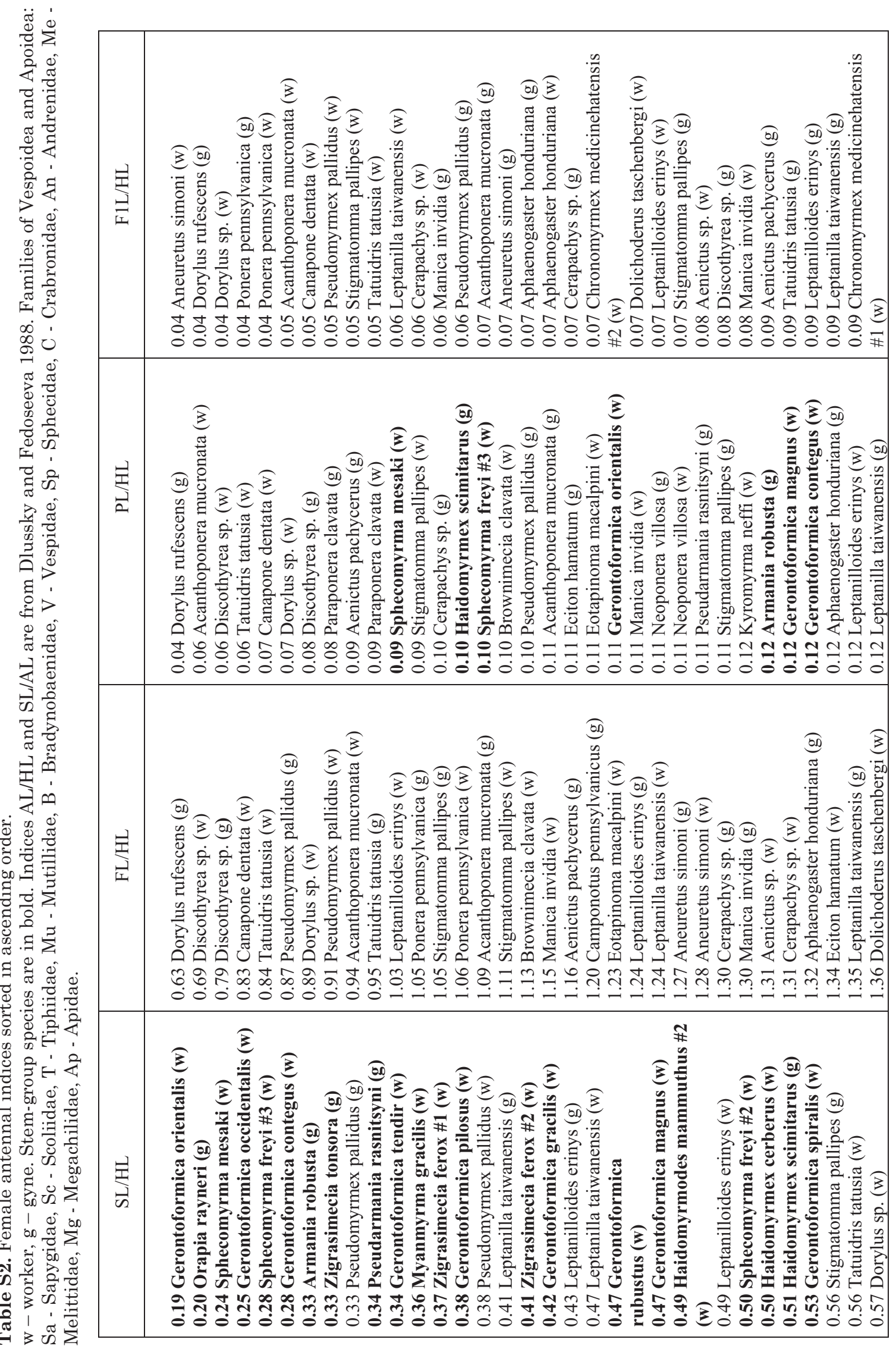




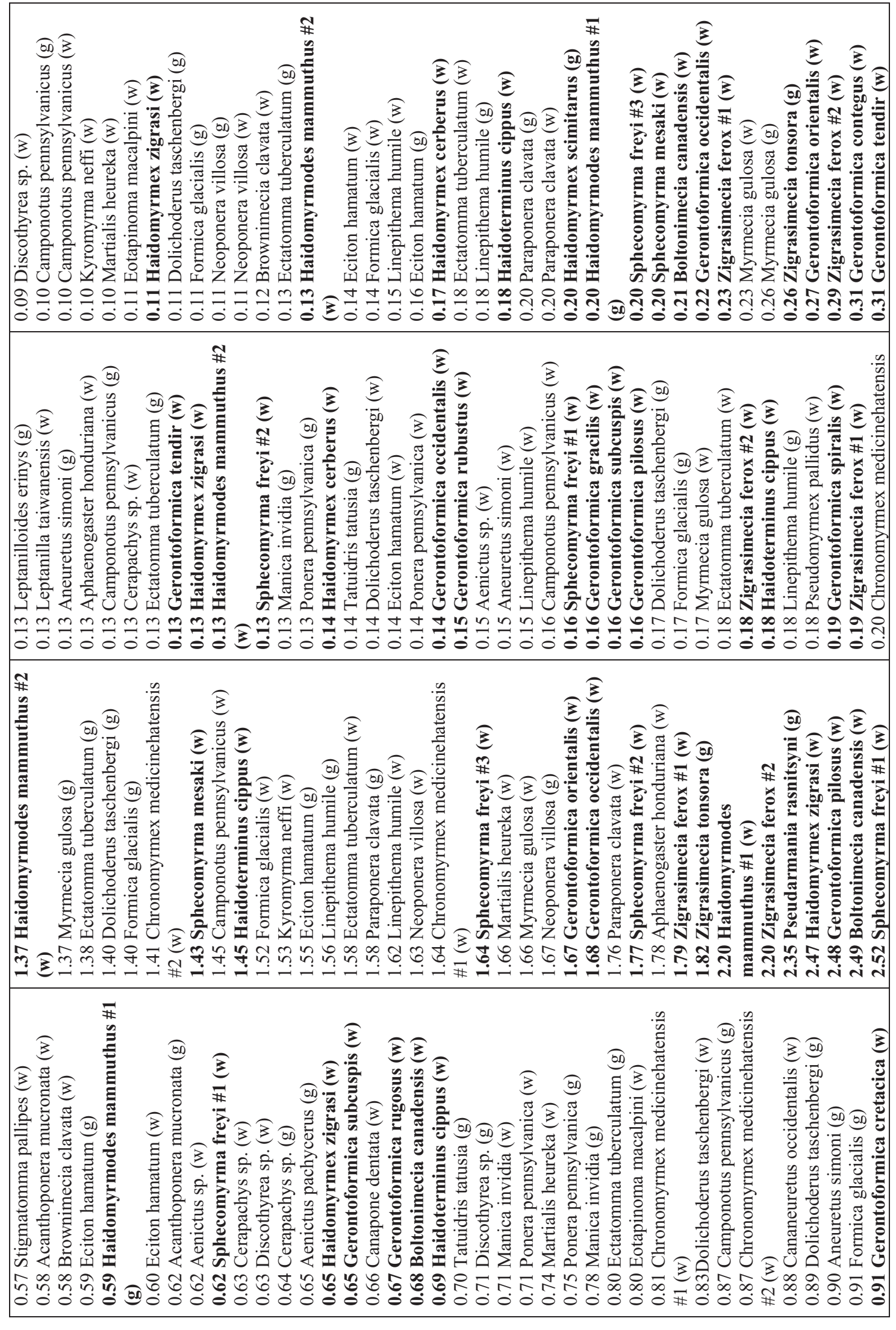




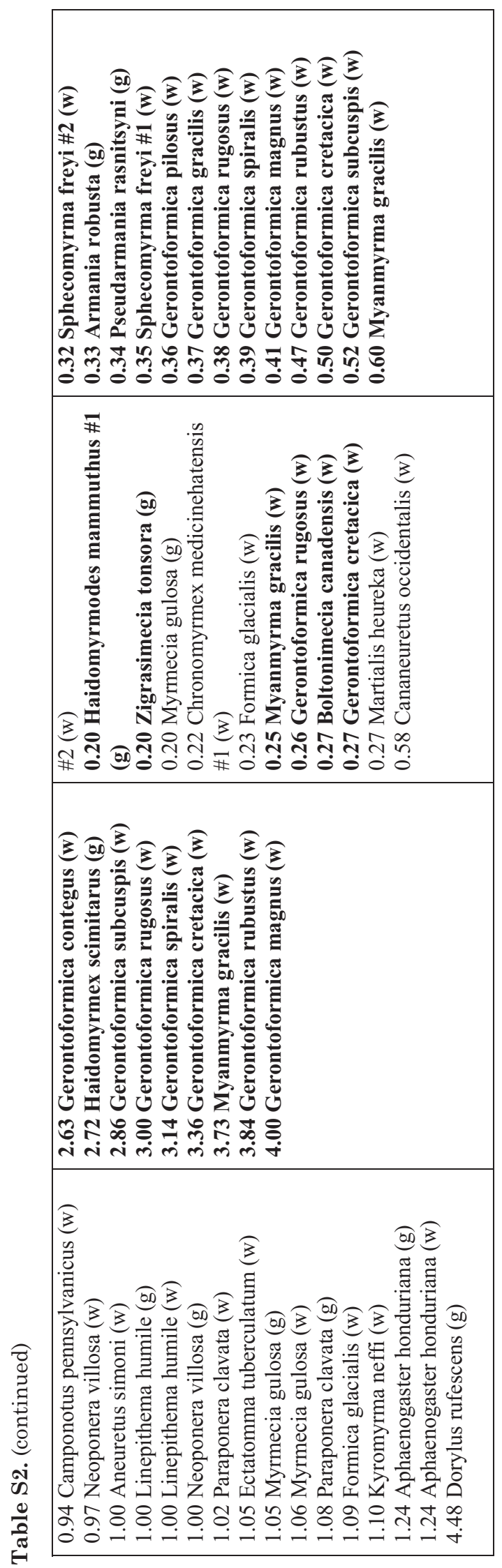




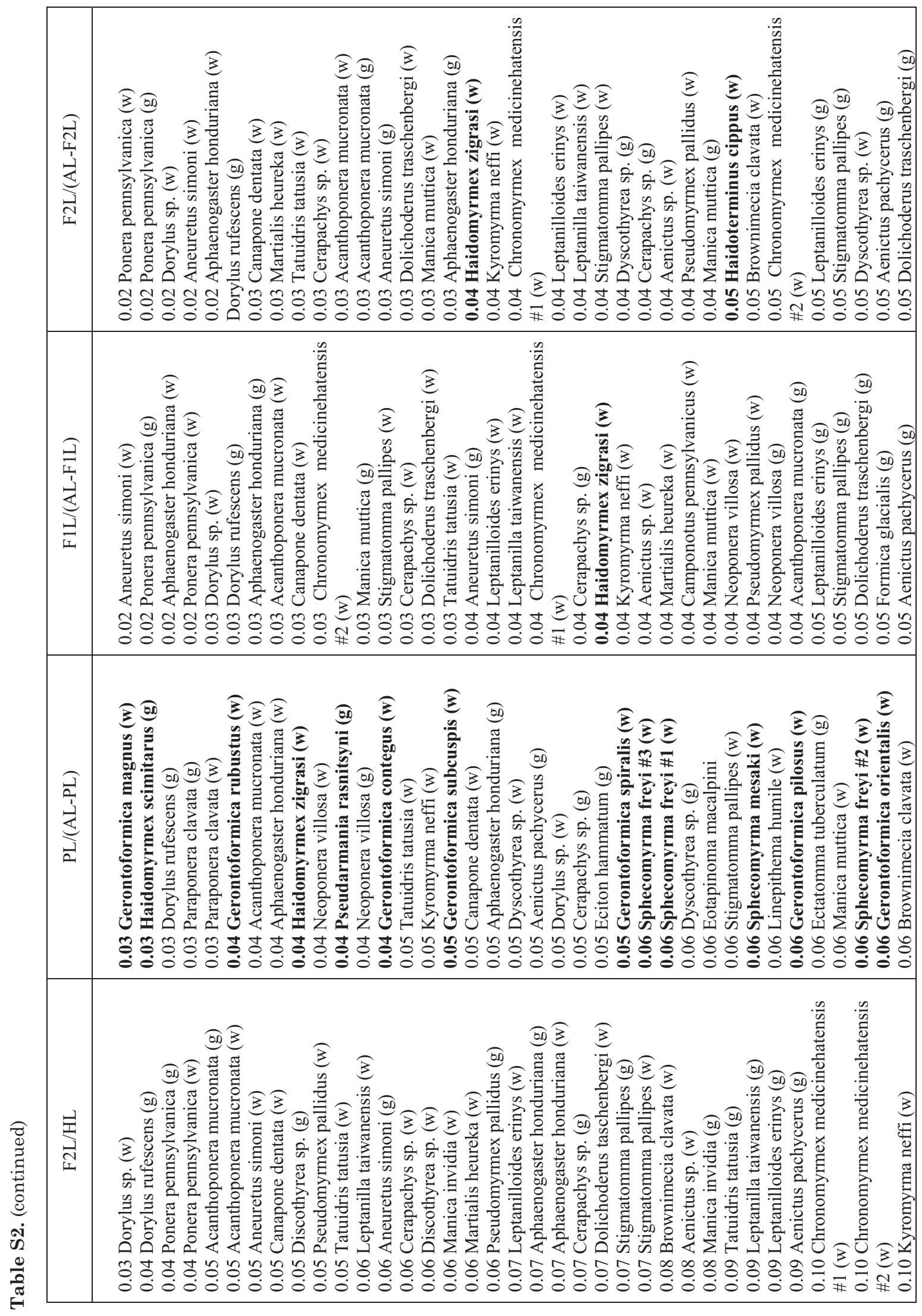




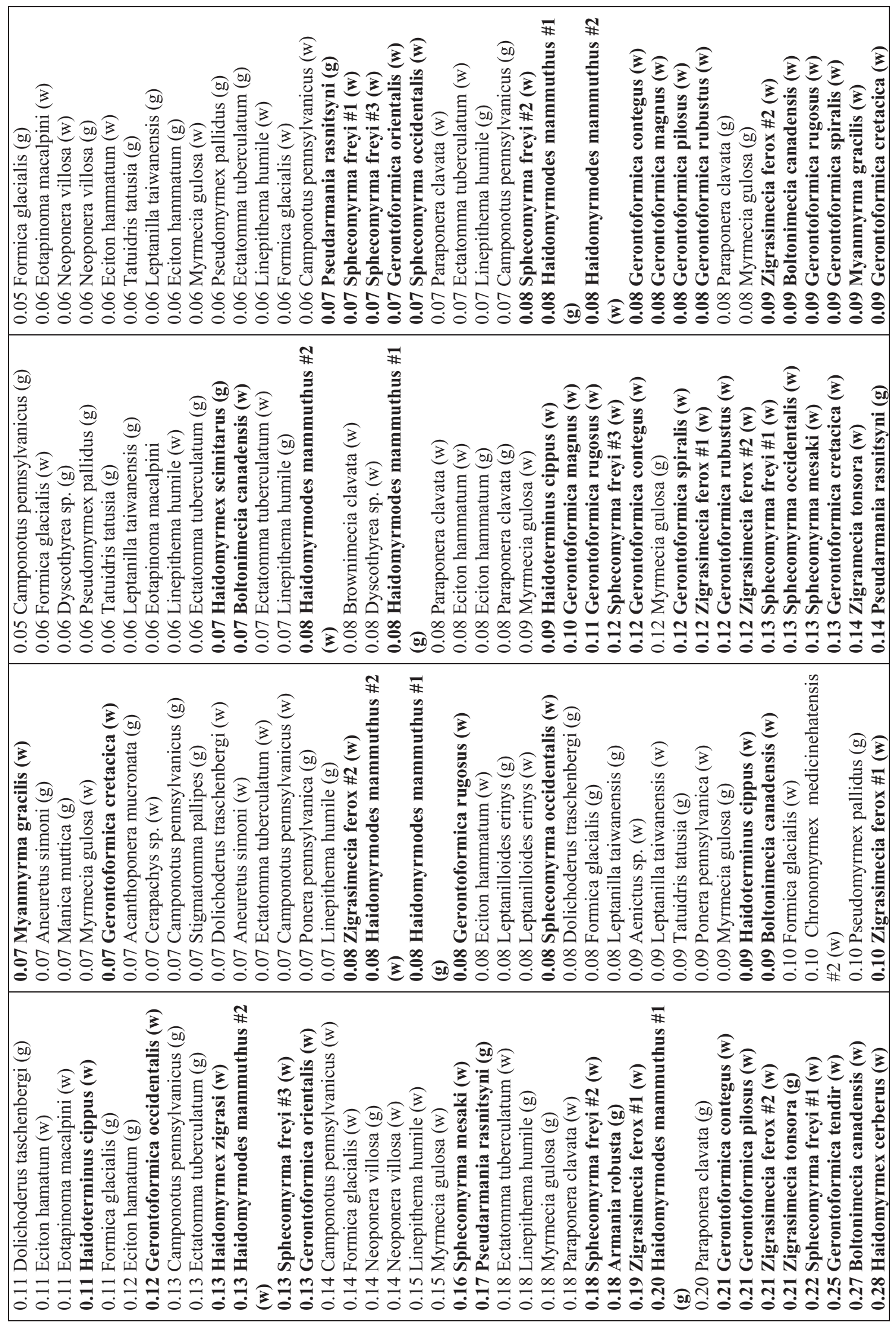




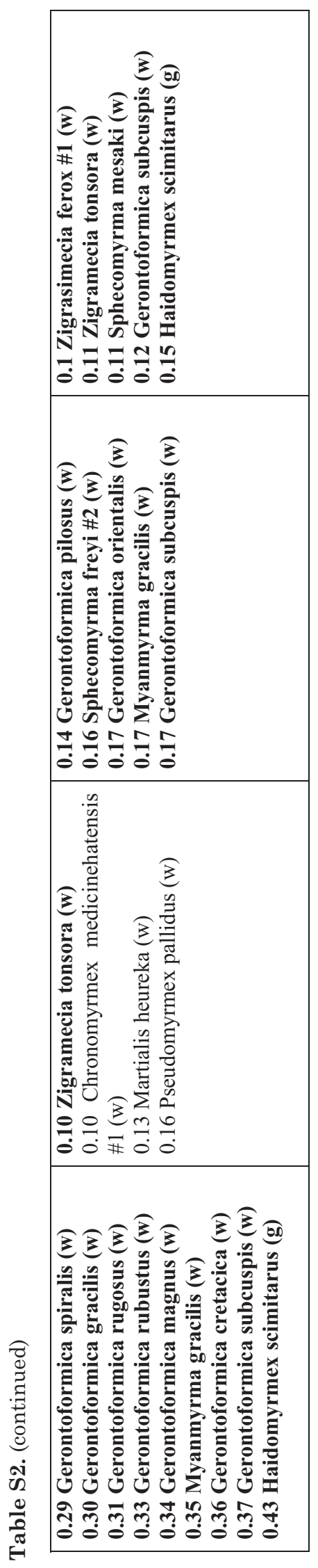


Table S2. (continued)

\begin{tabular}{|c|c|c|}
\hline SL/FL & AL/HL & SL/AL \\
\hline 0.10 Myanmyrma gracilis (w) & 1.05 Oxybellus sp. (C) & 0.09 Myanmyrma gracilis (w) \\
\hline 0.11 Gerontoformica contegus (w) & 1.09 Dasypoda plumipes (Me) & 0.10 Gerontoformica orientalis (w) \\
\hline 0.12 Gerontoformica magnus (w) & 1.10 Pseudomyrmex pallidus $(\mathrm{g})$ & 0.10 Gerontoformica contegus (w) \\
\hline 0.12 Gerontoformica rubustus (w) & 1.12 Dorylus rufescens $(\mathrm{g})$ & 0.11 Gerontoformica magnus (w) \\
\hline 0.12 Gerontoformica orientalis (w) & 1.17 Apis mellifera (Ap) & 0.11 Gerontoformica rubustus (w) \\
\hline 0.14 Pseudarmania rasnitsyni (g) & 1.20 Panurgus calcaratus (An) & 0.11 Methoca ichmeumonoides (T) \\
\hline 0.15 Gerontoformica occidentalis (w) & 1.22 Andrena hattorfiana (An) & 0.13 Agrogorytes mystaceus (C) \\
\hline 0.15 Gerontoformica pilosus (w) & 1.24 Bombus pascuorum (Ap) & 0.13 Ammophila sabulosa (Sp) \\
\hline 0.17 Gerontoformica spiralis (w) & 1.26 Euodynerus disconotatus (V) & 0.13 Gorytes quadrifasciatus (C) \\
\hline 0.17 Sphecomyrma freyi \#3 (w) & 1.26 Megachile lagopoda (Mg) & 0.13 Polochrum repandum $(\mathrm{Sa})$ \\
\hline 0.17 Sphecomyrma mesaki (w) & 1.28 Crossocerus sp. (C) & 0.13 Gerontoformica pilosus (w) \\
\hline 0.18 Zigrasimecia tonsora (g) & 1.29 Crabro cribrarius (C) & 0.13 Pseudarmania rasnitsyni (g) \\
\hline 0.19 Haidomyrmex scimitarus (g) & 1.29 Pseudomyrmex pallidus (w) & 0.13 Gerontoformica occidentalis (w) \\
\hline 0.19 Zigrasimecia ferox \#2 (w) & 1.31 Discothyrea sp. (w) & 0.13 Sphex funerarius $(\mathrm{Sp})$ \\
\hline 0.20 Zigrasimecia ferox \#1 (w) & 1.38 Bombus lapidarius (Ap) & 0.14 Sapyga caucasica $(\mathrm{Sa})$ \\
\hline 0.22 Gerontoformica rugosus (w) & 1.38 Bradynobaenus gayi (B) & 0.14 Sphecomyrma freyi \#3 (w) \\
\hline 0.23 Gerontoformica subcuspis (w) & 1.38 Mutilla europaea $(\mathrm{Mu})$ & 0.14 Sphecomyrma mesaki (w) \\
\hline 0.25 Sphecomyrma freyi \#1 (w) & 1.40 Bombus hypnorum (Ap) & 0.15 Proscolia spectator $(\mathrm{Sc})$ \\
\hline 0.26 Haidomyrmex zigrasi (w) & 1.41 Eucera dentata (Ap) & 0.15 Gerontoformica spiralis (w) \\
\hline 0.27 Boltonimecia canadensis (w) & 1.41 Tatuidris tatusia $(\mathrm{w})$ & 0.15 Zigrasimecia tonsora (g) \\
\hline 0.27 Haidomyrmodes mammuthus \#1 & 1.42 Symmorphus sp. (V) & 0.16 Haidomyrmex scimitarus (g) \\
\hline & 1.46 Dorylus sp. (w) & 0.16 Zigrasimecia ferox \#2 (w) \\
\hline 0.27 Gerontoformica cretacica (w) & 1.48 Meria discussa $(\mathrm{T})$ & 0.17 Zigrasimecia ferox \#1 (w) \\
\hline 0.27 Pseudomyrmex pallidus (g) & 1.49 Canapone dentata $(w)$ & 0.17 Typhoctes peculiaris (B) \\
\hline 0.28 Sphecomyrma freyi \#2 (w) & 1.50 Leptanilla taiwanensis (w) & 0.18 Gerontoformica rugosus (w) \\
\hline 0.32 Leptanilloides erinys (g) & 1.50 Discothyrea sp. (g) & 0.18 Fedtschenkia indigotea $(\mathrm{Sa})$ \\
\hline 0.33 Leptanilla taiwanensis (g) & 1.52 Acanthoponera mucronata (w) & 0.18 Meria discussa $(\mathrm{T})$ \\
\hline 0.36 Haidomyrmodes mammuthus \#2 & 1.56 Ancistrocerus parietinus (V) & 0.19 Eucera longicornis (Ap) \\
\hline & 1.56 Andrena rosae (An) & 0.19 Fedtschenkia anthracina $(\mathrm{Sa})$ \\
\hline 0.38 Eciton hamatum $(\mathrm{g})$ & 1.57 Bombus lucorum (Ap) & 0.19 Gerontoformica subcuspis (w) \\
\hline 0.39 Leptanilloides erinys $(\mathrm{w})$ & 1.57 Tiphia femorata $(\mathrm{T})$ & 0.20 Myrmosa atra $(\mathrm{Mu})$ \\
\hline 0.42 Pseudomyrmex pallidus (w) & 1.58 Vespa crabro $(\mathrm{V})$ & 0.20 Sphecomyrma freyi \#1 (w) \\
\hline 0.45 Martialis heureka $(w)$ & 1.60 Polistes gallicus $(\mathrm{V})$ & 0.21 Eucera dentata (Ap) \\
\hline 0.45 Eciton hamatum $(w)$ & 1.61 Eucera longicornis (Ap) & 0.21 Gerontoformica cretacica $(w)$ \\
\hline 0.45 Leptanilla taiwanensis $(\mathrm{w})$ & 1.61 Stigmatomma pallipes (g) & 0.21 Haidomyrmex zigrasi (w) \\
\hline 0.47 Aenictus sp. (w) & 1.65 Fedtschenkia anthracina $(\mathrm{Sa})$ & 0.21 Haidomyrmodes mammuthus \#1 \\
\hline 0.48 Haidoterminus cippus (w) & 1.65 Tatuidris tatusia $(\mathrm{g})$ & (g) \\
\hline 0.48 Cerapachys sp. (w) & 1.65 Leptanilla taiwanensis $(\mathrm{g})$ & 0.21 Pseudomyrmex pallidus (g) \\
\hline 0.49 Chronomyrmex medicinehatensis & 1.67 Sphecomyrma mesaki (w) & 0.22 Boltonimecia canadensis $(w)$ \\
\hline$\# 1(\mathrm{w})$ & 1.68 Stigmatomma pallipes (w) & 0.22 Dasypoda plumipes $(\mathrm{Me})$ \\
\hline 0.49 Cerapachys sp. (g) & 1.71 Acanthoponera mucronata $(\mathrm{g})$ & 0.22 Sphecomyrma freyi \#2 (w) \\
\hline 0.51 Brownimecia clavata $(\mathrm{w})$ & 1.71 Brownimecia clavata $(w)$ & 0.23 Andrena rosae $(\mathrm{An})$ \\
\hline 0.52 Stigmatomma pallipes (w) & 1.71 Fedtschenkia indigotea $(\mathrm{Sa})$ & 0.23 Apterogyna sp. (B) \\
\hline 0.53 Stigmatomma pallipes (g) & 1.73 Leptanilloides erinys (w) & 0.23 Brachycistis carinata $(\mathrm{T})$ \\
\hline 0.56 Aenictus pachycerus (g) & 1.74 Eumenes pedunculatus (V) & 0.23 Megachile lagopoda $(\mathrm{Mg})$ \\
\hline 0.57 Acanthoponera mucronata $(\mathrm{g})$ & 1.76 Proscolia spectator $(\mathrm{Sc})$ & 0.23 Pseudophotopsis sp. (Mu) \\
\hline 0.58 Paraponera clavata $(\mathrm{w})$ & 1.77 Ponera pennsylvanica $(\mathrm{w})$ & 0.23 Tiphia femorata $(\mathrm{T})$ \\
\hline 0.58 Ectatomma tuberculatum $(\mathrm{g})$ & 1.78 Pseudophotopsis sp. (Mu) & 0.24 Leptanilloides erinys $(\mathrm{g})$ \\
\hline 0.60 Neoponera villosa $(\mathrm{w})$ & 1.78 Leptanilloides erinys ( $\mathrm{g}$ ) & 0.25 Leptanilla taiwanensis $(\mathrm{g})$ \\
\hline 0.60 Neoponera villosa $(\mathrm{g})$ & 1.80 Ponera pennsylvanica $(\mathrm{g})$ & 0.25 Eumenes pedunculatus (V) \\
\hline 0.60 Manica invidia $(\mathrm{g})$ & 1.81 Aenictus pachycerus $(\mathrm{g})$ & 0.25 Oxybellus sp. $(\mathrm{C})$ \\
\hline 0.61 Acanthoponera mucronata (w) & 1.81 Brachycistis carinata $(\mathrm{T})$ & 0.25 Smicromyrme rufipes $(\mathrm{Mu})$ \\
\hline 0.61 Dolichoderus taschenbergi (w) & 1.82 Smicromyrme rufipes $(\mathrm{Mu})$ & 0.25 Vespula vulgaris $(\mathrm{V})$ \\
\hline
\end{tabular}


Table S2. (continued)

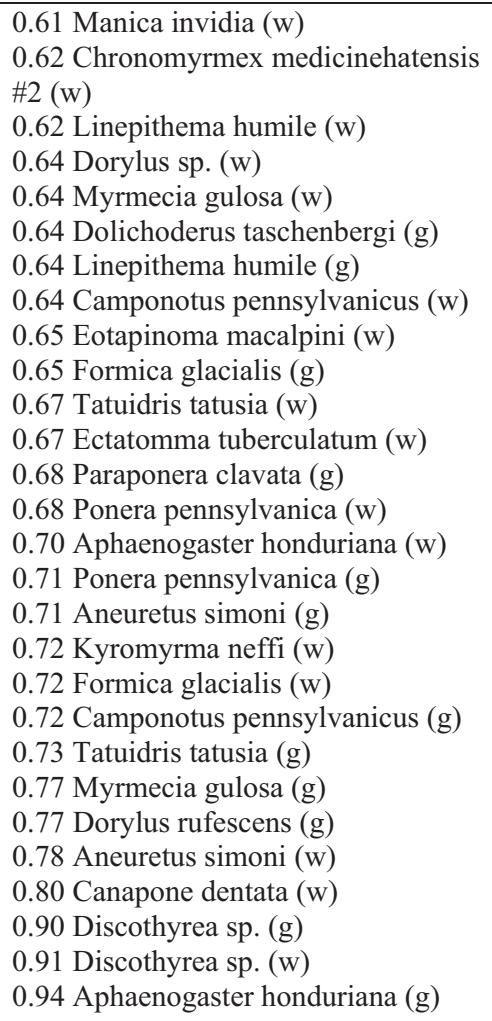

1.86 Manica invidia (w)
1.86 Gerontoformica orientalis (w)
1.87 Haidomyrmodes mammuthus

(w)

1.87 Vespula vulgaris (V)

1.88 Apterogyna sp. (B)

1.92 Aenictus sp. (w)

1.92 Sphecomyrma freyi \#3 (w)

1.93 Gerontoformica occidentalis (w)

1.94 Cerapachys sp. (w)

1.94 Eciton hamatum $(\mathrm{w})$

1.95 Cerapachys sp. (g)

1.96 Myrmosa atra $(\mathrm{Mu})$

2.00 Sphex funerarius $(\mathrm{Sp})$

2.03 Eotapinoma macalpini (w)

2.04 Sapyga caucasica $(\mathrm{Sa})$

2.04 Typhoctes peculiaris (B)

2.05 Gorytes quadrifasciatus $(\mathrm{C})$

2.07 Camponotus pennsylvanicus (g)

2.08 Manica invidia (g)

2.09 Methoca ichmeumonoides (T)

2.10 Ammophila sabulosa (Sp)

2.14 Eciton hamatum $(\mathrm{g})$

2.15 Haidoterminus cippus (w)

2.15 Zigrasimecia tonsora (g)

2.15 Zigrasimecia ferox \#1 (w)

2.61 Zigrasimecia ferox \#2 (w)

2.16 Aneuretus simoni (g)

2.18 Ectatomma tuberculatum $(\mathrm{g})$

2.19 Dolichoderus taschenbergi (w)

2.27 Sphecomyrma freyi \#2 (w)

2.28 Agrogorytes mystaceus (C)

2.28 Aneuretus simoni (w)

2.29 Chronomyrmex medicinehatensis

\#2 (w)

2.30 Dolichoderus taschenbergi (g)

2.31 Formica glacialis (g)

2.39 Camponotus pennsylvanicus (w)

2.40 Martialis heureka (w)

2.42 Myrmecia gulosa (g)

2.45 Chronomyrmex medicinehatensis

\#1 (w)

2.55 Aphaenogaster honduriana (g)

2.56 Linepithema humile (g)

2.60 Neoponera villosa (w)

2.61 Formica glacialis (w)

2.62 Linepithema humile (w)

2.62 Polochrum repandum $(\mathrm{Sa})$

2.63 Ectatomma tuberculatum (w)

2.63 Kyromyrma neffi

2.66 Paraponera clavata $(\mathrm{g})$

2.67 Neoponera villosa $(\mathrm{g})$

2.69 Pseudarmania rasnitsyni (g)

2.72 Myrmecia gulosa (w)

2.77 Paraponera clavata (w)

2.79 Haidomyrmodes mammuthus \#1
0.26 Haidomyrmodes mammuthus \#2 (w)

0.26 Mutilla europaea $(\mathrm{Mu})$

0.26 Symmorphus sp. (V)

0.26 Vespa crabro (V)

0.27 Eciton hamatum $(\mathrm{g})$

0.27 Panurgus calcaratus (An)

0.28 Andrena hattorfiana (An)

0.28 Bradynobaenus gayi (B)

0.28 Leptanilloides erinys $(\mathrm{w})$

0.30 Ancistrocerus parietinus (V)

0.30 Crossocerus sp.(C)

0.30 Polistes gallicus (V)

0.30 Pseudomyrmex pallidus (w)

0.31 Eciton hamatum (w)

0.31 Leptanilla taiwanensis (w)

0.31 Martialis heureka (w)

0.32 Aenictus sp. (w)

0.32 Apis mellifera (Ap)

0.32 Cerapachys sp. (w)

0.32 Euodynerus disconotatus (V)

0.32 Haidoterminus cippus (w)

0.33 Cerapachys sp. (g)

0.33 Chronomyrmex medicinehatensis

\#1 (w)

0.33 Crabro cribrarius $(\mathrm{C})$

0.34 Brownimecia clavata (w)

0.34 Stigmatomma pallipes (w)

0.35 Bombus lucorum (Ap)

0.35 Bombus pascuorum (Ap)

0.35 Stigmatomma pallipes $(\mathrm{g})$

0.36 Acanthoponera mucronata $(\mathrm{g})$

0.36 Aenictus pachycerus ( $g$ )

0.36 Bombus hypnorum (Ap)

0.36 Bombus lapidarius (Ap)

0.37 Ectatomma tuberculatum $(\mathrm{g})$

0.37 Neoponera villosa (w)

0.37 Paraponera clavata $(w)$

0.38 Acanthoponera mucronata (w)

0.38 Chronomyrmex medicinehatensis

\#2 (w)

0.38 Dolichoderus taschenbergi (w)

0.38 Linepithema humile (w)

0.38 Manica invidia (g)

0.38 Manica invidia (w)

0.38 Neoponera villosa (g)

0.39 Camponotus pennsylvanicus (w)

0.39 Dolichoderus taschenbergi (g)

0.39 Dorylus sp. (w)

0.39 Eotapinoma macalpini (w)

0.39 Linepithema humile $(\mathrm{g})$

0.39 Myrmecia gulosa (w)

0.40 Ectatomma tuberculatum (w)

0.40 Formica glacialis $(\mathrm{g})$

0.40 Ponera pennsylvanica (w)

0.40 Tatuidris tatusia (w) 
Table S2. (continued)

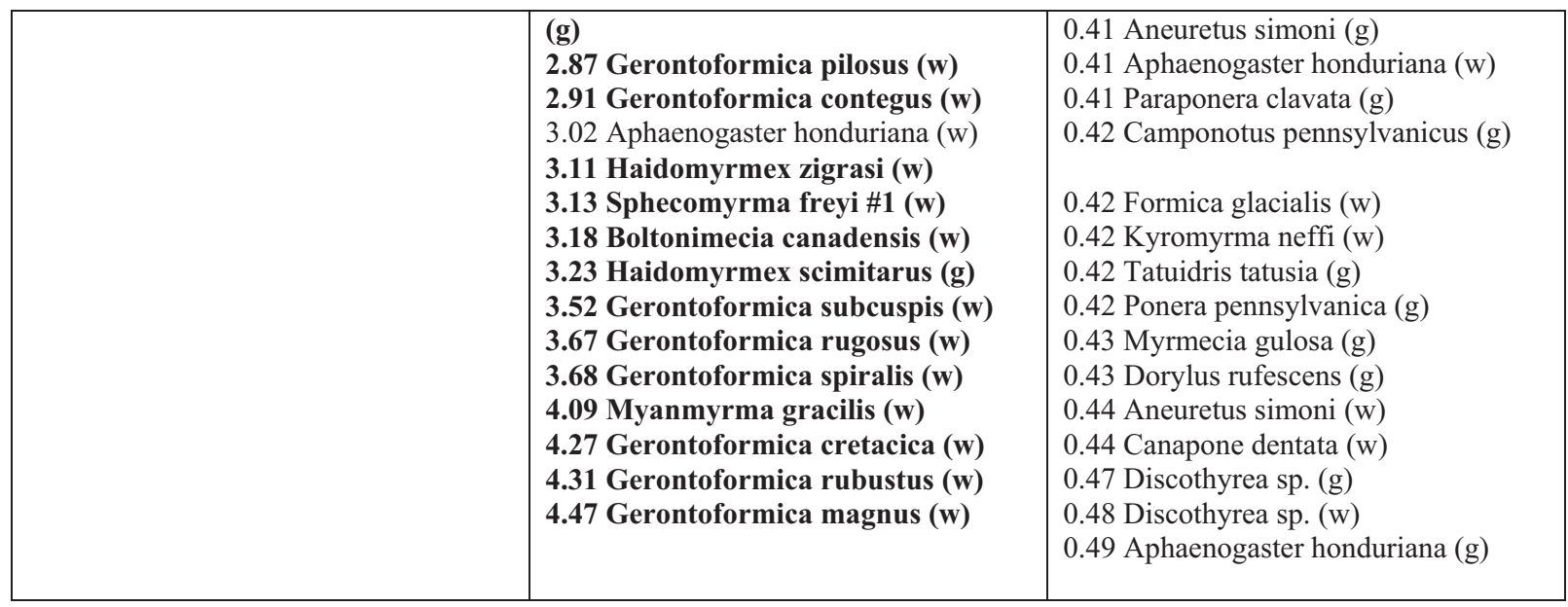


Table S3. Male antennal indices sorted in ascending order.

Cretaceous species are in bold.

\begin{tabular}{|c|c|c|}
\hline $\mathrm{SL} / \mathrm{HL}$ & FL/HL & PL/HL \\
\hline $\begin{array}{l}\text { 0.14 Tatuidris tatusia } \\
\text { 0.16 Ectatomma tuberculatum } \\
\text { 0.18 Baikuris mandibularis } \\
\text { 0.18 Neoponera villosa } \\
\text { 0.18 Ponera pennsylvanica } \\
\text { 0.19 Myrmecia sp. } \\
\text { 0.22 Baikuris maximus } \\
\text { 0.22 Acanthoponera mucronata } \\
\text { 0.22 Aneuretus simoni } \\
\text { 0.22 Manica invidia } \\
\text { 0.22 Stigmatomma pallipes } \\
\text { 0.25 Linepithema humile } \\
\text { 0.27 Paraponera clavata } \\
\text { 0.27 Pseudomyrmex pallidus } \\
\text { 0.20 Cerapachys sp. } \\
\text { 0.31 Dolichoderus taschenbergi } \\
\text { 0.31 Dlusskyidris zherichini } \\
\text { 0.32 Baikuris casei } \\
\text { 0.33Leptanilla sp. } \\
\text { 0.36 Aphaenogaster honduriana } \\
\text { 0.37 Shecomyrma sp. } \\
\text { 0.40 Discothyrea sp. } \\
\text { 0.46 Aenictogiton fossiceps } \\
\text { 0.50 Archaeopone taylori } \\
\text { 0.51 Leptanilloides mckennae } \\
\text { 0.60 Dorylus sp. } \\
\text { 0.72 Eciton hamatum } \\
\text { 1.07 Formica glacialis } \\
\text { 1.17 Camponotus pennsylvanicus } \\
\text { 1.22 Aenictus sp. }\end{array}$ & $\begin{array}{l}\text { 1.36 Aenictogiton fossiceps } \\
\text { 1.73 Dorylus sp. } \\
\text { 1.83 Leptanilla sp. } \\
\text { 1.86 Camponotus pennsylvanicus } \\
\text { 1.88 Linepithema humile } \\
\text { 2.11 Discothyrea sp. } \\
\text { 2.21 Eciton hamatum } \\
\text { 2.22 Pseudomyrmex pallidus } \\
\text { 2.35 Tatuidris tatusia } \\
\text { 2.36 Aphaenogaster honduriana } \\
\text { 2.44 Stigmatomma pallipes } \\
\text { 2.71 Formica glacialis } \\
\text { 3.06 Dolichoderus taschenbergi } \\
\text { 3.20 Baikuris mandibularis } \\
\text { 3.43 Aenictus sp. } \\
\text { 3.54 Dlusskyidris zherichini } \\
\text { 3.74 Leptanilloides mckennae } \\
\text { 3.75 Ponera pennsylvanica } \\
\text { 3.84 Cerapachys sp. } \\
\text { 3.85 Aneuretus simoni } \\
\text { 3.80 Manica invidia } \\
\text { 4.04 Myrmecia sp. } \\
\text { 4.43 Acanthoponera mucronata } \\
\text { 4.44 Shecomyrma sp. } \\
\text { 5.45 Paraponera clavata } \\
\text { 5.56 Baikuris maximus } \\
\text { 5.73 Baikuris casei } \\
\text { 6.21 Neoponera villosa } \\
\text { 6.44 Ectatomma tuberculatum }\end{array}$ & $\begin{array}{l}\text { 0.07 Dorylus sp. } \\
\text { 0.08 Myrmecia sp. } \\
\text { 0.09 Aneuretus simoni } \\
\text { 0.09 Baikuris mandibularis } \\
\text { 0.09 Discothyrea sp. } \\
\text { 0.09 Paraponera clavata } \\
\text { 0.09 Stigmatomma pallipes } \\
\text { 0.10 Cerapachys sp. } \\
\text { 0.10 Manica invidia } \\
\text { 0.10 Baikuris maximus } \\
\text { 0.11 Dlusskyidris zherichini } \\
\text { 0.11 Shecomyrma sp. } \\
\text { 0.11 Tatuidris tatusia } \\
\text { 0.11 Ectatomma tuberculatum } \\
\text { 0.11 Pseudomyrmex pallidus } \\
\text { 0.13 Linepithema humile } \\
\text { 0.14 Ponera pennsylvanica } \\
\text { 0.15 Aenictogiton fossiceps } \\
\text { 0.15 Aphaenogaster honduriana } \\
\text { 0.15 Archaeopone taylori } \\
\text { 0.15 Baikuris casei } \\
\text { 0.16 Dolichoderus taschenbergi } \\
\text { 0.17 Acanthoponera mucronata } \\
\text { 0.17 Leptanilla sp. } \\
\text { 0.17 Neoponera villosa } \\
\text { 0.18 Eciton hamatum } \\
\text { 0.19 Formica glacialis } \\
\text { 0.21 Camponotus pennsylvanicus } \\
\text { 0.23 Leptanilloides mckennae } \\
\text { 0.27 Aenictus sp. }\end{array}$ \\
\hline
\end{tabular}


Table S3. (continued)

\begin{tabular}{|c|c|c|}
\hline F1L/HL & F2L/HL & $\mathrm{SL} / \mathrm{FL}$ \\
\hline $\begin{array}{l}\text { 0.07 Dorylus sp. } \\
\text { 0.07 Aenictogiton fossiceps } \\
\text { 0.08 Leptanilla sp. } \\
\text { 0.13 Camponotus pennsylvanicus } \\
\text { 0.15 Tatuidris tatusia } \\
\text { 0.20 Aphaenogaster honduriana } \\
\text { 0.21 Eciton hamatum } \\
\text { 0.22 Discothyrea sp. } \\
\text { 0.22 Stigmatomma pallipes } \\
\text { 0.24 Formica glacialis } \\
\text { 0.27 Pseudomyrmex pallidus } \\
\text { 0.29 Aneuretus simoni } \\
\text { 0.30 Aenictus sp. } \\
\text { 0.30 Cerapachys sp. } \\
\text { 0.31 Dolichoderus taschenbergi } \\
\text { 0.32 Ponera pennsylvanica } \\
\text { 0.36 Manica invidia } \\
\mathbf{0 . 3 6} \text { Dlusskyidris zherichini } \\
\mathbf{0 . 3 7} \text { Shecomyrma sp. } \\
\text { 0.38 Linepithema humile } \\
\text { 0.38 Leptanilloides mckennae } \\
\text { 0.43 Acanthoponera mucronata } \\
\text { 0.46 Myrmecia sp. } \\
\mathbf{0 . 5 0} \text { Baikuris mandibularis } \\
\mathbf{0 . 6 3} \text { Baikuris casei } \\
\text { 0.68 Paraponera clavata } \\
\text { 0.69 Ectatomma tuberculatum } \\
\text { 0.71 Neoponera villosa } \\
\mathbf{0 . 7 2} \text { Baikuris maximus } \\
\text { 1.00 Archaeopone taylori }\end{array}$ & $\begin{array}{l}\text { 0.06 Aenictogiton fossiceps } \\
\text { 0.08 Leptanilla sp. } \\
\text { 0.11 Dorylus sp. } \\
\text { 0.15 Aphaenogaster honduriana } \\
\text { 0.15 Tatuidris tatusia } \\
\text { 0.17 Aneuretus simoni } \\
\text { 0.18 Discothyrea sp. } \\
\text { 0.18 Stigmatomma pallipes } \\
\text { 0.21 Camponotus pennsylvanicus } \\
\text { 0.21 Eciton hamatum } \\
\text { 0.21 Formica glacialis } \\
\text { 0.22 Dolichoderus taschenbergi } \\
\text { 0.22 Pseudomyrmex pallidus } \\
\text { 0.27 Aenictus sp. } \\
\text { 0.30 Manica invidia } \\
\text { 0.31 Linepithema humile } \\
\text { 0.32 Ponera pennsylvanica } \\
\text { 0.33 Dlusskyidris zherichini } \\
\mathbf{0 . 3 4} \text { Baikuris mandibularis } \\
\mathbf{0 . 3 5} \text { Shecomyrma sp. } \\
\text { 0.36 Leptanilloides mckennae } \\
\text { 0.40 Cerapachys sp. } \\
\text { 0.46 Myrmecia sp. } \\
\text { 0.48 Acanthoponera mucronata } \\
\text { 0.55 Archaeopone taylori } \\
\mathbf{0 . 5 7} \text { Baikuris maximus } \\
\text { 0.59 Paraponera clavata } \\
\mathbf{0 . 6 7} \text { Baikuris casei } \\
\text { 0.69 Ectatomma tuberculatum } \\
\text { 0.69 Neoponera villosa }\end{array}$ & $\begin{array}{l}\text { 0.02 Ectatomma tuberculatum } \\
\text { 0.03 Neoponera villosa } \\
\text { 0.04 Leptanilloides mckennae } \\
\text { 0.04 Baikuris maximus } \\
\text { 0.05 Baikuris mandibularis } \\
\text { 0.05 Acanthoponera mucronata } \\
\text { 0.05 Paraponera clavata } \\
\text { 0.05 Ponera pennsylvanica } \\
\text { 0.05 Cerapachys sp. } \\
\text { 0.05 Myrmecia sp. } \\
\text { 0.06 Baikuris casei } \\
\text { 0.06 Aneuretus simoni } \\
\text { 0.06 Tatuidris tatusia } \\
\text { 0.06 Manica invidia } \\
\text { 0.08 Sphecomyrma sp. } \\
\text { 0.09 Dlusskyidris zherichini } \\
\text { 0.09 Stigmatomma pallipes } \\
\text { 0.10 Dolichoderus taschenbergi } \\
\text { 0.12 Pseudomyrmex pallidus } \\
\text { 0.13 Linepithema humile } \\
\text { 0.15 Aphaenogaster honduriana } \\
\text { 0.18 Leptanilla sp. } \\
\text { 0.19 Discothyrea sp. } \\
\text { 0.33 Eciton hamatum } \\
\text { 0.34 Aenictogiton fossiceps } \\
\text { 0.35 Dorylus sp. } \\
\text { 0.35 Aenictus sp. } \\
\text { 0.39 Formica glacialis } \\
\text { 0.63 Camponotus pennsylvanicus }\end{array}$ \\
\hline
\end{tabular}


Table S3. (continued)

\begin{tabular}{|c|c|c|}
\hline PL/(AL-PL) & F1L/(AL-F1L) & $\mathrm{F} 2 \mathrm{~L} /(\mathrm{AL}-\mathrm{F} 2 \mathrm{~L})$ \\
\hline $\begin{array}{l}\text { 0.02 Paraponera clavata } \\
\text { 0.02 Ectatomma tuberculatum } \\
\mathbf{0 . 0 2} \text { Baikuris maximus } \\
\text { 0.02 Myrmecia sp. } \\
\text { 0.02 Aneuretus simoni } \\
\mathbf{0 . 0 2} \text { Shecomyrma sp. } \\
\mathbf{0 . 0 3} \text { Baikuris casei } \\
\text { 0.03 Cerapachys sp. } \\
\text { 0.03 Manica muttica } \\
\mathbf{0 . 0 3} \text { Baikuris mandibularis } \\
\text { 0.03 Neoponera villosa } \\
\mathbf{0 . 0 3} \text { Dlusskyridris zherihini } \\
\text { 0.03 Dorylus sp. } \\
\text { 0.03 Stigmatomma pallipes } \\
\text { 0.04 Acanthoponera mucronata } \\
\text { 0.04 Tatuidris tatusia } \\
\text { 0.04 Dyscothyrea sp. } \\
\text { 0.04 Ponera pennsylvanica } \\
\text { 0.05 Pseudomyrmex pallidus } \\
\text { 0.05 Dolichoderus traschenbergi } \\
\text { 0.05 Formica glacialis } \\
\text { 0.06 Leptanilloides mckennae } \\
\text { 0.06 Aphaenogaster honduriana } \\
\text { 0.06 Aenictus sp. } \\
\text { 0.06 Linepithema humile } \\
\text { 0.06 Eciton hammatum } \\
\text { 0.08 Camponotus pennsylvanicus } \\
\text { 0.08 Leptanilla sp. } \\
\text { 0.09 Aenictogiton fossiceps }\end{array}$ & $\begin{array}{l}\text { 0.03 Dorylus sp. } \\
\text { 0.04 Aenictogiton fossiceps } \\
\text { 0.04 Leptanilla sp. } \\
\text { 0.04 Camponotus pennsylvanicus } \\
\text { 0.06 Tatuidris tatusia } \\
\text { 0.07 Aenictus sp. } \\
\text { 0.07 Formica glacialis } \\
\text { 0.08 Aneuretus simoni } \\
\text { 0.08 Aphaenogaster honduriana } \\
\text { 0.08 Eciton hammatum } \\
\text { 0.08 Cerapachys sp. } \\
\text { 0.08 Shecomyrma sp. } \\
\text { 0.09 Ponera pennsylvanica } \\
\text { 0.09 Stigmatomma pallipes } \\
\text { 0.10 Leptanilloides mckennae } \\
\text { 0.10 Dyscothyrea sp. } \\
\text { 0.10 Acanthoponera mucronata } \\
\text { 0.10 Manica muttica } \\
\text { 0.10 Dlusskyridris zherihini } \\
\text { 0.10 Dolichoderus traschenbergi } \\
\text { 0.12 Baikuris casei } \\
\text { 0.12 Ectatomma tuberculatum } \\
\text { 0.12 Pseudomyrmex pallidus } \\
\text { 0.12 Myrmecia sp. } \\
\text { 0.13 Neoponera villosa } \\
\text { 0.14 Paraponera clavata } \\
\text { 0.14 Baikuris maximus } \\
\text { 0.17 Baikuris mandibularis } \\
\text { 0.21 Linepithema humile }\end{array}$ & $\begin{array}{l}\text { 0.03 Aenictogiton fossiceps } \\
\text { 0.04 Leptanilla sp. } \\
\text { 0.04 Aneuretus simoni } \\
\text { 0.05 Dorylus sp. } \\
\text { 0.06 Aphaenogaster honduriana } \\
\text { 0.06 Formica glacialis } \\
\text { 0.06 Tatuidris tatusia } \\
\text { 0.06 Aenictus sp. } \\
\text { 0.07 Dolichoderus traschenbergi } \\
\text { 0.07 Stigmatomma pallipes } \\
\text { 0.08 Camponotus pennsylvanicus } \\
\text { 0.08 Eciton hammatum } \\
\text { 0.08 Dyscothyrea sp. } \\
\text { 0.08 Shecomyrma sp. } \\
\text { 0.08 Manica muttica } \\
\text { 0.09 Ponera pennsylvanica } \\
\text { 0.09 Leptanilloides mckennae } \\
\text { 0.09 Dlusskyridris zherihini } \\
\text { 0.10 Pseudomyrmex pallidus } \\
\text { 0.11 Cerapachys sp. } \\
\text { 0.11 Acanthoponera mucronata } \\
\text { 0.11 Baikuris maximus } \\
\text { 0.11 Baikuris mandibularis } \\
\text { 0.12 Paraponera clavata } \\
\text { 0.12 Ectatomma tuberculatum } \\
\text { 0.12 Neoponera villosa } \\
\text { 0.12 Myrmecia sp. } \\
\text { 0.12 Baikuris casei } \\
\text { 0.17 Linepithema humile }\end{array}$ \\
\hline
\end{tabular}


Table S4. P-values for comparisons of the indices SL/HL in females.

Results are from ANOVA with planned comparisons. Below the name of each group: arithmetic mean \pm standard deviation; [max; $\min ] ; \mathrm{n}=$ number of specimens. Crown - all extant crown-group ants from Table S1; Cretaceous crown - genera Kyromyrma, Canapone, Eotapinoma, Chronomyrmex; Sphecomyrmini - genera Sphecomyrma, Gerontoformica, Zigrasimecia; Haidomyrmecini - genera Haidomyrmex, Haidomyrmodes, Haidoterminus; Sphecomyrminae - Sphecomyrmini+Haidomyrmecini; Armaniinae - genera Armania, Pseudarmania, Orapia.

\begin{tabular}{|c|c|c|c|c|c|c|c|}
\hline & $\begin{array}{c}\text { crown } \\
0.76 \pm 0.23[0.33 ; \\
1.24] n=47\end{array}$ & $\begin{array}{c}\text { Cretaceous crown } \\
0.84 \pm 0.16[0.66 \\
1.10] n=5\end{array}$ & $\begin{array}{c}\text { Sphecomyrmini } \\
0.41 \pm 0.14[0.19 \\
0.67] n=18\end{array}$ & $\begin{array}{c}\text { Haidomyrmecini } \\
0.57 \pm 0.08[0.49 ; \\
0.69] n=6\end{array}$ & $\begin{array}{c}\text { Armaniinae } \\
0.29 \pm 0.07[0.20 \\
0.34] n=3\end{array}$ & $\begin{array}{c}\text { Sphecomyrminae } \\
0.45 \pm 0.15[0.19 \\
0.69] n=24\end{array}$ & $\begin{array}{c}\text { Sphecomyrminae } \\
\text { +Armaniinae } \\
0.43 \pm 0.15[0.19 ; \\
0.69] n=27 \\
\end{array}$ \\
\hline crown & & 0.34 & 0.0001 & 0.08 & 0.0001 & 0.0001 & 0.0001 \\
\hline Sphecomyrmini & & & & 0.01 & 0.12 & & \\
\hline Haidomyrmecini & & & & & 0.003 & & \\
\hline Armaniinae & & & & 0.01 & & & \\
\hline
\end{tabular}

Table S5. P-values for comparisons of the indices FL/HL in females.

See Table $\mathrm{S} 4$ note for details.

\begin{tabular}{|c|c|c|c|c|c|}
\hline & $\begin{array}{c}\text { crown } \\
1.27 \pm 0.29[0.63 ; 1.78] \\
n=47\end{array}$ & $\begin{array}{c}\text { Cretaceous crown } \\
1.32 \pm 0.32[0.83 ; 1.64] \\
n=5\end{array}$ & $\begin{array}{c}\text { Sphecomyrmini } \\
2.40 \pm 0.80[1.43 ; 4.00] \\
n=16\end{array}$ & $\begin{array}{c}\text { Haidomyrmecini } \\
2.04 \pm 0.60[1.37 ; 2.72] \\
n=5\end{array}$ & $\begin{array}{c}\text { Sphecomyrminae } \\
2.32 \pm 0.76[1.37 ; 4.00] \\
n=21\end{array}$ \\
\hline crown & & 0.71 & 0.0001 & 0.0001 & 0.0001 \\
\hline Sphecomyrmini & & & & 0.28 & \\
\hline
\end{tabular}

Table S6. P-values for comparisons of the indices PL/HL in females. See Table $\mathrm{S} 4$ note for details.

\begin{tabular}{|c|c|c|c|c|c|c|c|}
\hline & $\begin{array}{c}\text { crown } \\
0.13 \pm 0.04[0.04 \\
0.27] n=47\end{array}$ & $\begin{array}{c}\text { Cretaceous crown } \\
0.14 \pm 0.06[0.07 \\
0.22] n=5\end{array}$ & $\begin{array}{c}\text { Sphecomyrmini } \\
0.15 \pm 0.04[0.09 ; \\
0.26] n=18\end{array}$ & $\begin{array}{c}\text { Haidomyrmecini } \\
0.15 \pm 0.04[0.10 ; \\
0.20] n=6\end{array}$ & $\begin{array}{c}\text { Armaniinae } \\
0.11 \pm 0.005[0.11 \\
0.12] n=2\end{array}$ & $\begin{array}{c}\text { Sphecomyrminae } \\
0.15 \pm 0.04[0.09 \\
0.26] n=24\end{array}$ & $\begin{array}{c}\text { Sphecomyrminae } \\
\text { +Armaniinae } \\
0.15 \pm 0.04[0.09 ; \\
0.26] n=26\end{array}$ \\
\hline crown & & 0.59 & 0.03 & 0.24 & 0.89 & 0.04 & 0.28 \\
\hline Sphecomyrmini & & & & 0.82 & 0.33 & & \\
\hline Haidomyrmecini & & & & & 0.45 & & \\
\hline Armaniinae & & & & & & 0.37 & \\
\hline
\end{tabular}

Table S7. P-values for comparisons of the indices F1L/HL in females. See Table S4 note for details.

\begin{tabular}{|c|c|c|c|c|c|c|c|}
\hline & $\begin{array}{c}\text { crown } \\
0.10 \pm 0.05[0.04 ; \\
0.26] n=47\end{array}$ & $\begin{array}{c}\text { Cretaceous crown } \\
0.08 \pm 0.02[0.05 \\
0.11] n=5\end{array}$ & $\begin{array}{c}\text { Sphecomyrmini } \\
0.32 \pm 0.09[0.20 ; \\
0.52] n=18\end{array}$ & $\begin{array}{c}\text { Haidomyrmecini } \\
0.17 \pm 0.03[0.11 \\
0.20] n=6\end{array}$ & $\begin{array}{c}\text { Armaniinae } \\
0.33 \pm 0.002[0.33 \\
0.34] n=2\end{array}$ & $\begin{array}{c}\text { Sphecomyrminae } \\
0.28 \pm 0.10[0.11 \\
0.52] n=24\end{array}$ & $\begin{array}{c}\text { Sphecomyrminae } \\
\text { +Armaniinae } \\
0.29 \pm 0.10[0.11 ; \\
0.52] n=26\end{array}$ \\
\hline crown & & 0.69 & 0.0001 & 0.001 & 0.0001 & 0.0001 & 0.0001 \\
\hline Sphecomyrmini & & & & 0.002 & 0.83 & & \\
\hline Haidomyrmecini & & & & & 0.04 & & \\
\hline Armaniinae & & & & & & 0.22 & \\
\hline
\end{tabular}


Table S8. P-values for comparisons of the indices F2L/HL in females.

See Table S4 note for details.

\begin{tabular}{|c|c|c|c|c|c|c|c|}
\hline & $\begin{array}{c}\text { crown } \\
0.09 \pm 0.05[0.03 ; \\
0.28] n=47\end{array}$ & $\begin{array}{c}\text { Cretaceous crown } \\
0.09 \pm 0.03[0.05 \\
0.11] n=5\end{array}$ & $\begin{array}{c}\text { Sphecomyrmini } \\
0.23 \pm 0.08[0.12 \\
0.37] n=18\end{array}$ & $\begin{array}{c}\text { Haidomyrmecini } \\
0.21 \pm 0.12[0.11 \\
0.43] n=6\end{array}$ & $\begin{array}{c}\text { Armaniinae } \\
0.17 \pm 0.01[0.17 \\
0.18] n=2\end{array}$ & $\begin{array}{c}\text { Sphecomyrminae } \\
0.23 \pm 0.09[0.11 \\
0.43] n=24\end{array}$ & $\begin{array}{c}\text { Sphecomyrminae } \\
\text { +Armaniinae } \\
0.22 \pm 0.08[0.11 ; \\
0.43] n=26 \\
\end{array}$ \\
\hline crown & & 0.77 & 0.0001 & 0.0001 & 0.03 & 0.0001 & 0.0001 \\
\hline Sphecomyrmini & & & & 0.51 & 0.50 & & \\
\hline Haidomyrmecini & & & & & 0.81 & & \\
\hline Armaniinae & & & & & & 0.64 & \\
\hline
\end{tabular}

Table S9. P-values for comparisons of the indices SL/FL in females.

See Table S4 note for details

\begin{tabular}{|c|c|c|c|c|c|}
\hline & $\begin{array}{c}\text { crown } \\
0.60 \pm 0.15[0.27 ; 0.94] \\
n=47\end{array}$ & $\begin{array}{c}\text { Cretaceous crown } \\
0.66 \pm 0.11[0.49 ; 0.80] \\
n=5\end{array}$ & $\begin{array}{c}\text { Sphecomyrmini } \\
0.18 \pm 0.05[0.11 ; 0.28] \\
n=16\end{array}$ & $\begin{array}{c}\text { Haidomyrmecini } \\
0.31 \pm 0.11[0.19 ; 0.48] \\
n=5\end{array}$ & $\begin{array}{c}\text { Sphecomyrminae } \\
0.21 \pm 0.09[0.11 ; 0.48] \\
n=21\end{array}$ \\
\hline crown & & 0.43 & 0.0001 & 0.0001 & 0.0001 \\
\hline Sphecomyrmini & & & & 0.0001 & \\
\hline
\end{tabular}

Table S10. P-values for comparisons of the indices PL/(AL-PL) in females.

See Table S4 note for details.

\begin{tabular}{|c|c|c|c|c|c|}
\hline & $\begin{array}{c}\text { crown } \\
0.07 \pm 0.02[0.03 ; 0.16] \\
n=47\end{array}$ & $\begin{array}{c}\text { Cretaceous crown } \\
0.07 \pm 0.03[0.05 ; 0.10] \\
n=5\end{array}$ & $\begin{array}{c}\text { Sphecomyrmini } \\
0.06 \pm 0.02[0.03 ; 0.10] \\
n=16\end{array}$ & $\begin{array}{c}\text { Haidomyrmecini } \\
0.06 \pm 0.02[0.03 ; 0.09] \\
n=5\end{array}$ & $\begin{array}{c}\text { Sphecomyrminae } \\
0.06 \pm 0.02[0.03 ; 0.10] \\
n=21\end{array}$ \\
\hline crown & & 0.94 & 0.34 & 0.69 & 0.43 \\
\hline Sphecomyrmini & & & & 0.86 & \\
\hline
\end{tabular}

Table S11. P-values for comparisons of the indices F1L/(AL-F1L) in females.

See Table S4 note for details.

\begin{tabular}{|c|c|c|c|c|c|}
\hline & $\begin{array}{c}\text { crown } \\
0.05 \pm 0.02[0.02 ; 0.12] \\
n=47\end{array}$ & $\begin{array}{c}\text { Cretaceous crown } \\
0.04 \pm 0.01[0.03 ; 0.06] \\
n=5\end{array}$ & $\begin{array}{c}\text { Sphecomyrmini } \\
0.13 \pm 0.02[0.10 ; 0.17] \\
n=16\end{array}$ & $\begin{array}{c}\text { Haidomyrmecini } \\
0.07 \pm 0.02[0.04 ; 0.09] \\
n=5\end{array}$ & $\begin{array}{c}\text { Sphecomyrminae } \\
0.12 \pm 0.03[0.04 ; 0.17] \\
n=21\end{array}$ \\
\hline crown & & 0.20 & 0.0001 & 0.06 & 0.0001 \\
\hline Sphecomyrmini & & & & 0.01 & \\
\hline
\end{tabular}


Table S12. P-values for comparisons of the indices F2L/(AL-F2L) in females. See Table S4 note for details.

\begin{tabular}{|c|c|c|c|c|c|}
\hline & $\begin{array}{c}\text { crown } \\
0.05 \pm 0.02[0.02 ; 0.08] \\
n=47\end{array}$ & $\begin{array}{c}\text { Cretaceous crown } \\
0.04 \pm 0.009[0.03 ; 0.06] \\
n=5\end{array}$ & $\begin{array}{c}\text { Sphecomyrmini } \\
0.09 \pm 0.01[0.07 ; 0.12] \\
n=16\end{array}$ & $\begin{array}{c}\text { Haidomyrmecini } \\
0.08 \pm 0.04[0.04 ; 0.15] \\
n=5\end{array}$ & $\begin{array}{c}\text { Sphecomyrminae } \\
0.08 \pm 0.02[0.04 ; 0.15] \\
n=21\end{array}$ \\
\hline crown & & 0.84 & 0.0001 & 0.07 & 0.002 \\
\hline Sphecomyrmini & & & & 0.51 & \\
\hline
\end{tabular}

Table S13. P-values for comparisons of the indices SL/AL in females.

Results are from ANOVA with planned comparisons. Data on Vespoidea and Apoidea are from Dlussky and Fedoseeva (1988), sorted by families according to the current classification. Vespoidea: families Sapygidae, Scoliidae, Tiphiidae, Mutillidae, Bradynobaenidae, Vespidae. Apoidea: families Sphecidae, Crabronidae, Andrenidae, Melittidae, Megachilidae, Apidae. Social Hymenoptera: Vespa sp., Vespula sp., Polistes sp., Apis sp. (1 species each), Bombus sp. (4 species). Stem ants: all stem-group ants from Table S1. Crown ants: all crown-group ants from Table S1. Below the name of each group: arithmetic mean \pm standard deviation; [max; min]; $n=$ number of specimens.

\begin{tabular}{cccccc}
\hline & crown ants & Stem ants & Vespoidea & Apoidea & social \\
& $0.37 \pm 0.06[0.21 ;$ & $0.17 \pm 0.05[0.09 ;$ & $0.21 \pm 0.06[0.11 ;$ & $0.22 \pm 0.07[0.13 ;$ & $0.32 \pm 0.04[0.25 ;$ \\
& $0.49] n=47$ & $0.32] n=25$ & $0.32] n=20$ & $0.33] n=14$ & $0.36] n=8$ \\
\hline crown ants & & 0.0001 & 0.0001 & 0.0001 & 0.02 \\
\hline stem ants & & & 0.009 & 0.01 & 0.0001 \\
\hline
\end{tabular}

Table S14. P-values for comparisons of the indices AL/HL in females. See Table S13 note for details.

\begin{tabular}{cccccc}
\hline & crown ants & Stem ants & Vespoidea & Apoidea & social \\
& $2.03 \pm 0.48[1.10 ;$ & $2.90 \pm 0.85[1.7 ;$ & $1.75 \pm 0.31[1.3 ;$ & $1.53 \pm 0.41[1.1 ;$ & $1.48 \pm 0.22[1.2 ;$ \\
& $3.02] n=47$ & $4.5] n=25$ & $2.6] n=20$ & $2.3] n=14$ & $1.9] n=8$ \\
\hline crown ants & & 0.0001 & 0.01 & 0.002 & 0.0001 \\
\hline stem ants & & & 0.0001 & 0.0001 & 0.0001 \\
\hline
\end{tabular}

Table S15. T- and p-values for comparisons of the antennal indices in males.

Results are from Student's unpaired t test. Species are listed in Table S3. Arithmetic mean \pm standard deviation; [max; $\min ] ; \mathrm{n}=$ number of specimens.

\begin{tabular}{cccc}
\hline index & Cretaceous & crown & t-value (p-value) \\
\hline SL/HL & $0.32 \pm 0.11[0,18 ; 0,50] \mathrm{n}=6$ & $0.41 \pm 0.32[0.14 ; 1.22] \mathrm{n}=24$ & $0.34(0.73)$ \\
\hline FL/HL & $4.49 \pm 1.14[3.20 ; 5.73] \mathrm{n}=5$ & $3.21 \pm 1.39[1.36 ; 6.44] \mathrm{n}=24$ & $1.91(0.07)$ \\
\hline $\mathrm{PL} / \mathrm{HL}$ & $0.12 \pm 0.02[0.09 ; 0.15] \mathrm{n}=6$ & $0.14 \pm 0.05[0.07 ; 0.27] \mathrm{n}=24$ & $0.79(0.43)$ \\
\hline $\mathrm{F} 1 \mathrm{~L} / \mathrm{HL}$ & $0.59 \pm 0.24[0.36 ; 1.00] \mathrm{n}=6$ & $0.31 \pm 0.18[0.07 ; 0.71] \mathrm{n}=24$ & $2.73(0.01)$ \\
\hline F2L/HL & $0.47 \pm 0.15[0.33 ; 0.67] \mathrm{n}=6$ & $0.29 \pm 0.18[0.06 ; 0.69] \mathrm{n}=24$ & $2.23(0.03)$ \\
\hline SL/FL & $0.06 \pm 0.02[0.04 ; 0.09] \mathrm{n}=5$ & $0.17 \pm 0.15[0.02 ; 0.63] \mathrm{n}=24$ & $2.52(0.02)$ \\
\hline $\mathrm{PL} /(\mathrm{AL}-\mathrm{HL})$ & $0.03 \pm 0.004[0.02 ; 0.03] \mathrm{n}=5$ & $0.04 \pm 0.02[0.02 ; 0.09] \mathrm{n}=24$ & $2.09(0.05)$ \\
\hline F1L/(AL-F1L) & $0.12 \pm 0.03[0.08 ; 0.17] \mathrm{n}=5$ & $0.09 \pm 0.04[0.03 ; 0.21] \mathrm{n}=24$ & $1.85(0.08)$ \\
\hline F2L/(AL-F2L) & $0.08 \pm 0.04[0.08 ; 0.12] \mathrm{n}=5$ & $0.08 \pm 0.03[0.03 ; 0.17] \mathrm{n}=24$ & $1.31(0.20)$ \\
\hline
\end{tabular}


Table S16. Comparisons of the length of flagellomeres.

T- and p-values are from Student's paired t test. See tables S3 and S4 for details of the groups.

\begin{tabular}{|c|c|c|c|c|c|c|}
\hline \multirow[t]{2}{*}{ group } & \multicolumn{2}{|c|}{ F1L and PL } & \multicolumn{2}{|c|}{ F2L and PL } & \multicolumn{2}{|c|}{ F1L and F2L } \\
\hline & $\begin{array}{c}\text { F1L/PL }) \times 1 \\
00, \%\end{array}$ & $\begin{array}{l}\text { t-value (p- } \\
\text { value) }\end{array}$ & $\begin{array}{c}(\mathrm{F} 2 \mathrm{~L} / \mathrm{PL}) \times 1 \\
00, \%\end{array}$ & $\begin{array}{l}\text { t-value (p- } \\
\text { value) }\end{array}$ & $\begin{array}{c}(\mathrm{F} 1 \mathrm{~L} / \mathrm{F} 2 \mathrm{~L}) \times \\
100, \%\end{array}$ & $\begin{array}{l}\text { t-value (p- } \\
\text { value) }\end{array}$ \\
\hline extant crown-group females & 81 & $\begin{array}{c}4.49 \\
(0.0001)\end{array}$ & 77 & $\begin{array}{c}4.98 \\
(0.0001)\end{array}$ & 105 & $1.11(0.27)$ \\
\hline $\begin{array}{c}\text { Cretaceous crown-group } \\
\text { females }\end{array}$ & 66 & $2.42(0.07)$ & 71 & $2.46(0.07)$ & 90 & $1.88(0.13)$ \\
\hline Sphecomyrmini & 219 & $\begin{array}{c}10.53 \\
(0.0001)\end{array}$ & 154 & $\begin{array}{c}5.11 \\
(0.0001)\end{array}$ & 144 & $\begin{array}{c}8.87 \\
(0.0001)\end{array}$ \\
\hline Haidomyrmecini & 119 & $1.01(0.35)$ & 167 & $0.96(0.38)$ & 93 & $0.82(0.45)$ \\
\hline Sphecomyrminae & 193 & $\begin{array}{c}7.19 \\
(0.0001) \\
\end{array}$ & 158 & $\begin{array}{c}4.06 \\
(0.0001) \\
\end{array}$ & 132 & $3.32(0.003)$ \\
\hline Crown-group males & 254 & $3.54(0.001)$ & 237 & $3.64(0.001)$ & 108 & $0.16(0.9)$ \\
\hline Cretaceous males & 504 & $5.11(0.004)$ & 413 & $6.58(0.001)$ & 137 & $1.78(0.13)$ \\
\hline
\end{tabular}


Table S17. Female discriminant scores used in Fig. 6, sorted in ascending order. $\mathrm{w}$ - worker, g-gyne. Stem-group species are in bold.

\begin{tabular}{|c|c|}
\hline Fig. 6A & Fig. 6B \\
\hline 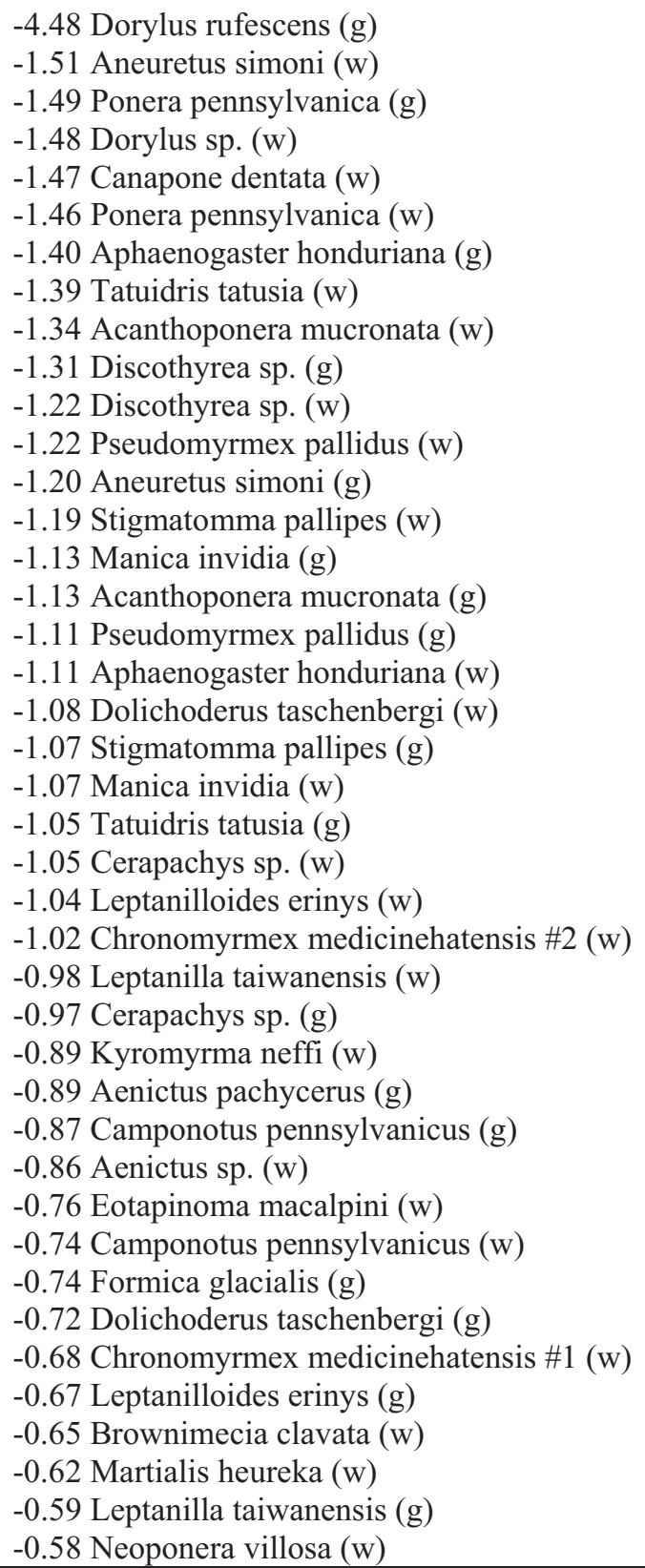 & 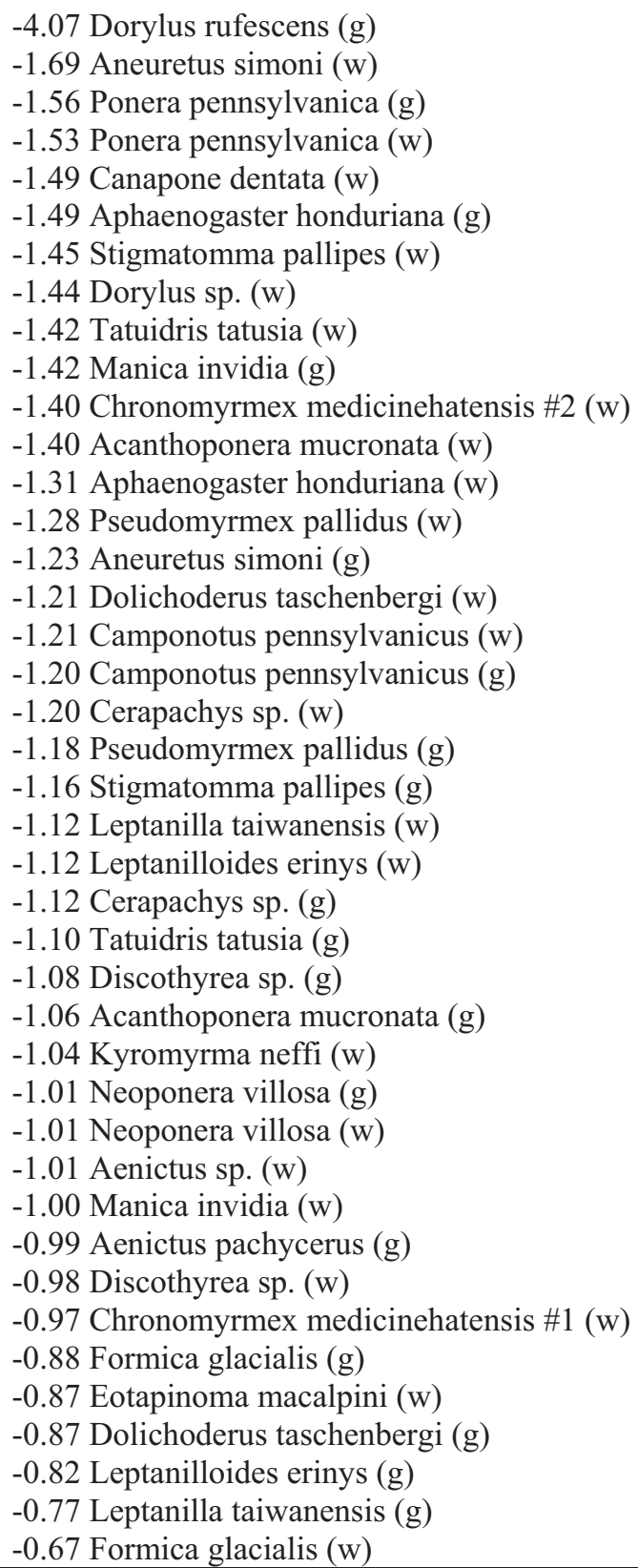 \\
\hline
\end{tabular}




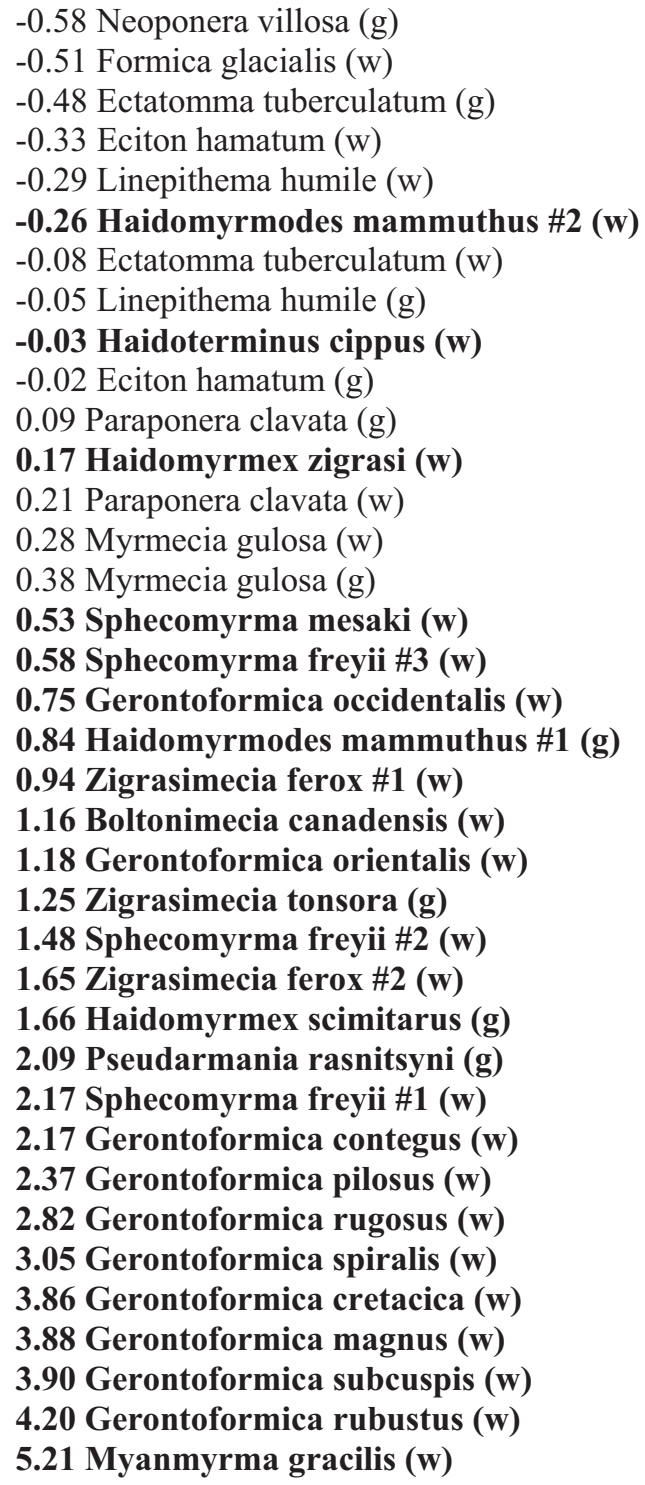

-0.63 Ectatomma tuberculatum (g)

-0.53 Martialis heureka (w)

-0.48 Linepithema humile (w)

-0.44 Brownimecia clavata (w)

-0.25 Ectatomma tuberculatum (w)

-0.25 Eciton hamatum (w)

-0.23 Linepithema humile (g)

-0.09 Paraponera clavata (g)

0.08 Eciton hamatum (g)

0.14 Paraponera clavata (w)

0.24 Boltonimecia canadensis (w)

0.63 Sphecomyrma mesaki (w)

0.71 Myrmecia gulosa (w)

0.86 Sphecomyrma freyii \#3 (w)

0.89 Myrmecia gulosa (g)

0.96 Zigrasimecia ferox \#1 (w)

1.26 Gerontoformica occidentalis (w)

1.33 Zigrasimecia tonsora (g)

1.88 Zigrasimecia ferox \#2 (w)

2.00 Gerontoformica orientalis (w)

2.30 Sphecomyrma freyii \#2 (w)

2.43 Gerontoformica contegus (w)

2.72 Sphecomyrma freyii \#1 (w)

2.79 Gerontoformica rugosus (w)

2.98 Pseudarmania rasnitsyni (g)

3.07 Gerontoformica pilosus (w)

3.21 Gerontoformica spiralis (w)

3.57 Gerontoformica magnus (w)

4.31 Gerontoformica cretacica (w)

4.49 Gerontoformica rubustus (w)

4.53 Gerontoformica subcuspis (w) 6.38 Myanmyrma gracilis (w) 
Table S18. Phylogenetic definition of the subclades of Formicidae ${ }^{\mathrm{P}}$.

Reference phylogenies: Ward 1990; Baroni-Urbani et al. 1992; Brandão et al. 1999; Brady et al. 2006, 2014; Moreau et al. 2006; Ward et al. 2010; Schmidt 2013; Ward et al. 2015, 2016; Ward and Fisher 2016.

\begin{tabular}{|c|c|}
\hline Converted clade name & Clade definition \\
\hline Martialinae $^{\mathrm{P}}$ Rabeling, Brown and Verhaagh 2008 & $\begin{array}{l}\text { The clade comprised of Martialis heureka Rabeling, Brown and Verhaagh } 2008 \text { and all } \\
\text { species that share a more recent common ancestor with Martialis heureka Rabeling, Brown } \\
\text { and Verhaagh } 2008 \text { than with Leptanilla revelierii Emery, } 1870\end{array}$ \\
\hline Leptanillinae $^{\mathrm{P}}$ Wheeler, 1923 & $\begin{array}{l}\text { The clade originating with the most recent common ancestor of Leptanilla revelierii Emery, } \\
1870 \text {, Protanilla rafflesi Bolton, } 1990 \text { and Anomalomyrma taylori Bolton, } 1990\end{array}$ \\
\hline Proceratiinae $^{\mathrm{P}}$ Bolton, 2003 & $\begin{array}{l}\text { The clade originating with the most recent common ancestor of Proceratium silaceum } \\
\text { Roger, J. } 1863 \text { and Probolomyrmex tani Fisher, } 2007\end{array}$ \\
\hline Apomyrminae $e^{\mathrm{P}}$ Dlussky and Fedoseeva, 1988 & $\begin{array}{l}\text { The clade comprised of Apomyrma stygia Brown, Gotwald and Lévieux, } 1971 \text { and all } \\
\text { species that share a more recent common ancestor with Apomyrma stygia Brown, Gotwald } \\
\text { and Lévieux, } 1971 \text { than with Amblyopone australis Erichson, } 1842\end{array}$ \\
\hline Amblyoponinae ${ }^{\mathrm{P}}$ Forel, 1893 & $\begin{array}{l}\text { The clade originating with the most recent common ancestor of Amblyopone australis } \\
\text { Erichson, } 1842 \text {, Onychomyrmex hedleyi Emery, } 1895 \text { and Bannapone mulanae Xu, } 2000\end{array}$ \\
\hline Ponerinae ${ }^{\mathrm{P}}$ Ashmead, 1905 & $\begin{array}{l}\text { The clade originating with the most recent common ancestor of Ponera coarctata (Latreille, } \\
\text { 1802), Platythyrea punctata (Smith, F., 1858) and Anochetus mayri Emery, } 1884\end{array}$ \\
\hline Paraponerinae $^{\mathrm{P}}$ Bolton, 2003 & $\begin{array}{l}\text { The clade comprised of Paraponera clavata (Fabricius, 1775) and all species that share a } \\
\text { more recent common ancestor with Paraponera clavata (Fabricius, 1775) than with } \\
\text { Tatuidris tatusia Brown and Kempf, } 1968\end{array}$ \\
\hline Agroecomyrmecinae ${ }^{\mathrm{P}}$ Bolton, 2003 & $\begin{array}{l}\text { The clade originating with the most recent common ancestor of Tatuidris tatusia Brown and } \\
\text { Kempf, } 1968 \text { and Ankylomyrma coronacantha Bolton, } 1973\end{array}$ \\
\hline Dorylinae ${ }^{\mathrm{P}}$ Ashmead, 1905 & $\begin{array}{l}\text { The clade originating with the most recent common ancestor of Dorylus helvolus (Linnaeus, } \\
\text { 1764), Vicinopone conciliatrix (Brown, 1975) and Leptanilloides biconstricta Mann, } 1923\end{array}$ \\
\hline Myrmeciinae $^{\mathrm{P}}$ Ashmead, 1905 & $\begin{array}{l}\text { The clade originating with the most recent common ancestor of Myrmecia gulosa } \\
\text { (Fabricius, 1775) and Nothomyrmecia macrops Clark, } 1934\end{array}$ \\
\hline Pseudomyrmecinae $^{\mathrm{P}}$ Smith, 1952 & $\begin{array}{l}\text { The clade originating with the most recent common ancestor of Pseudomyrmex gracilis } \\
\text { (Fabricius, 1804), Myrcidris epicharis Ward, } 1990 \text { and Tetraponera punctulata Smith, F., } \\
1877\end{array}$ \\
\hline Ectatomminae $^{\mathrm{P}}$ Bolton, 2003 & $\begin{array}{l}\text { The clade originating with the most recent common ancestor of Ectatomma tuberculatum } \\
\text { (Olivier, 1792) and Gnamptogenys striatula Mayr, } 1884\end{array}$ \\
\hline Heteroponerinae $^{\mathrm{P}}$ Bolton, 2003 & $\begin{array}{l}\text { The clade originating with the most recent common ancestor of Heteroponera carinifrons } \\
\text { Mayr, 1887, Acanthoponera mucronata (Roger, 1860) and Aulacopone relicta Arnol'di, } 1930\end{array}$ \\
\hline Aneuretinae $\mathrm{P}^{\mathrm{P}}$ Clark, 1951 & $\begin{array}{l}\text { The clade comprised of Aneuretus simoni Emery, 1893a and all species that share a more } \\
\text { recent common ancestor with Aneuretus simoni Emery, 1893a than with Dolichoderus } \\
\text { attelaboides (Fabricius, 1775) }\end{array}$ \\
\hline Dolichoderinae $^{\mathrm{P}}$ Forel, 1893 & $\begin{array}{l}\text { The clade originating with the most recent common ancestor of Dolichoderus attelaboides } \\
\text { (Fabricius, 1775), Tapinoma sessile (Say, 1836) and Linepithema humile (Mayr, 1868) }\end{array}$ \\
\hline Formicinae $^{\mathrm{P}}$ Ashmead, 1905 & $\begin{array}{l}\text { The clade originating with the most recent common ancestor of Formica rufa Linnaeus, } \\
\text { 1761, Myrmelachista flavocotea Longino, 2006, and Camponotus pennsylvanicus (De Geer, } \\
\text { 1773) }\end{array}$ \\
\hline Myrmicinae $^{\mathrm{P}}$ Ashmead, 1905 & $\begin{array}{l}\text { The clade originating with the most recent common ancestor of Myrmica rubra (Linnaeus, } \\
1758 \text { ), Temnothorax rugatulus (Emery, 1895) and Monomorium pharaonis (Linnaeus, 1758) }\end{array}$ \\
\hline
\end{tabular}


